UNIVERSIDADE DE SÃO PAULO

FACULDADE DE FILOSOFIA, LETRAS E CIÊNCIAS HUMANAS

DEPARTAMENTO DE LÍNGUÍSTICA

PROGRAMA DE PÓS-GRADUAÇÃO EM SEMIÓTICA E LINGUÍSTICA GERAL

\title{
A MORFOLOGIA DO INDICATIVO NA EXPRESSÃO DO MODO SUBJUNTIVO EM SÃO PAULO E SÃO LUÍS
}

\author{
WENDEL SANTOS
}

Dissertação apresentada ao Programa de PósGraduação em Semiótica e Linguística Geral do Departamento de Linguística da Faculdade de Filosofia, Letras e Ciências Humanas da Universidade de São Paulo para obtenção do título de Mestre em Linguística.

Orientador: Prof. Dr. Ronald Beline Mendes

São Paulo

2014 
Para Mamãe, por quem faz sentido tudo isso.

Para Pedro, que chegou em minha vida para "atrapalhar de eternidade" (adaptado de Fabricio Carpinejar). 


\title{
Agradecimentos
}

\begin{abstract}
AS MÃOS
Com mãos se faz a paz se faz a guerra/Com mãos tudo se faz e se desfaz./Com mãos se faz o poema - e são de terra./Com mãos se faz a guerra - e são a paz./Com mãos se rasga o mar./Com mãos se lavra./Não são de pedras estas casas mas de mãos./E estão no fruto e na palavra/as mãos que são o canto e são as armas./E cravam-se no Tempo como farpas/as mãos que vês nas coisas transformadas./Folhas que vão no vento: verdes harpas./De mãos é cada flor cada cidade./Ninguém pode vencer estas espadas:/nas mãos começa a liberdade.
\end{abstract}

Adaptado de Manuel Alegre, em 'O Canto e as Armas”

Os resultados a que chegou esse trabalho é a junção de muitas mãos. Quer sejam elas ludovicenses ou paulistanas, as mãos que serão "citadas" a seguir foram, ao longo desses 30 meses, sustento, às vezes acalento, para que eu continuasse seguindo. No contexto ludovicense, agradeço:

- À minha mãe, cujas mãos vem dadas às minhas, permitindo-me, por meio de seus "empurrõezinhos" específicos para cada situação dessa vida, conquistar coisas que nem eu mesmo esperava que acontecessem. É por ela também tudo isso;

- $\quad$ Aos meus irmãos, cujas mãos transmitem proteção e carinho. Obrigado por um tanto de coisas vividas. Obrigado também pelos dinheiros: eles foram essenciais!

- $\quad$ À professora Conceição Ramos, por ter me ensinado a dar os primeiros passos nos estudos linguísticos. Foi ela quem me fez compreender que hoje eu faço exatamente aquilo que eu quero pra minha vida profissional. Obrigado por ter acreditado em mim.

- Aos professores Fátima e Mendes, por ter contribuído para o meu crescimento acadêmico e pessoal. À Georgiana, pela amizade e pelo carinho que nos une.

- $\quad$ À Cibelle, companheira de análises linguísticas e análises da vida também; à Julianne, meu anjo de luz nessa terra, e à Alana, doçura que se vê na alma, por caminharem de mãos dadas comigo.

- Ao Projeto ALiMA, por ainda fazer parte de minha vida acadêmica, e por me proporcionar um refúgio acadêmico em terras ludovicenses. Impossível dizer que não amo.

- $\quad$ À Danny, por ser a "mão" mais louca que tenho nessa vida. Rir com ela é um remédio e tanto para acreditar mais ainda na vida.

- $\quad$ Ao Pedro, a "mão" que redirecionou o meu olhar sobre a vida, e que me fez entender que nunca é tarde para se refazer planos e redirecionar pensamentos. Ele é a minha mão luz! 
- Por fim, agradeço a cada um dos meus 36 informantes, por ter compartilhado comigo um pouco de sua visão sobre o mundo, e, assim, ter garantido a realização desse estudo. Eles nem imaginam o quanto me ajudaram.

No contexto paulistano, agradeço:

- Ao professor Ronald, por ter mais do que aceito me orientar; por ter me acolhido, e por ter contribuído para o meu amadurecimento pessoal e profissional. A firmeza de seu "acompanhamento" me fez certo de que eu posso ir adiante.

- Aos professores com os quais eu tive a oportunidade de aprender um pouco mais: Cristina Altman, quando da seleção para ingresso no programa de Pósgraduação; Olga Coelho, por ter contribuído para o amadurecimento de meu trabalho; Margarida Petter, por sempre me mostrar exemplos da expressão do subjuntivo em línguas africanas; Irenilde dos Santos, pelas melhores aulas de Geolinguistica que eu poderia ter; Esmeralda, pelo cuidado com que sempre acolheu minha pesquisa e por todas as suas dicas quando do exame de qualificação deste trabalho. Agradeço a Tatiana Pimpão, pela leitura do meu trabalho e por disponibilizar muitos daqueles que são aqui citados.

- $\quad$ Aos amigos que conquistei na USP e que compartilharam momentos únicos em minha passagem por São Paulo: Jacqueline Harsche, por sua meiguice única; Sinalva Fernandes, pela capacidade de sempre olhar com olhos de amor os problemas da vida; Alline Evelyn, por transmitir paz através de sua doce e amável voz; Julia Chiovetto, por ser, sem dúvidas, a minha paulistana mais prototípica, e por me dar os exemplos mais lindos da expressão do modo subjuntivo na terra que "não tem subjuntivo"; Wellington da Silva, por compartilhar muito de seu conhecimento acadêmico. A esse grupo de amigos "uspianos", acrescento os nomes da Jul Fernandes, Juliana Osorno, Rodrigo Madrid e do Gabriel da Cunha, pelas ótimas conversas e pela amizade, claro.

- Ao GESOL, por aquecer a minha vida acadêmica através dos muitos estudos recentes sobre a sociolinguística. Por também ter me proporcionado o melhor grupo que uma pessoa possa ter em sua pós-graduação: à Dayane, pela amizade e pelo senso de humor até nas horas em que a "sisudice" teimava em imperar; à Amanda, pelos contextos de subjuntivo, mas principalmente pelas conversas, passeios e muitas gargalhadas divididas, e pela amizade que vai pra sempre; ao Rafael Rocha, por ter me acolhido amigavelmente lá no iniciozinho da pós; ao Rafael Ciancio;

- $\quad$ Em especial, eu agradeço à Lívia Oushiro, por sua amizade, pelos muitos conselhos, por olhar com cuidado para os meus dados, por ter contribuído tão diretamente para que as minhas análises fossem as melhores possiveis. Dizer obrigado é pouco demais diante da ajuda que me deste.

- Mais especialmente ainda, agradeço à Marília, por tudo que fez por mim, desde a seleção para o mestrado, por me acolher em sua casa, que depois viria a ser nossa; 
por ter sido uma irmã paulistana ao longo desse tempo. À Mariane, pela amizade sempre em prontidão; por também olhar os meus dados, por me ajudar a tomar decisões, e por ter estado sempre interessada em meu bem estar (meu agradecimento à Mari se estende também ao Ricardo Marquezin). E à Larissa, a "menina cujos óculos são da cor dos cabelos", pela graça de sua companhia, pelas reflexões maduras, que refletem um olhar impar sobre um mundo tão chato às vezes. Eu já disse que São Paulo não é fria. Ela tem a nós. (Os meus agradecimentos à Larissa se estendem ao Renan)

- Ao Marcelo e ao Vitor, meus roommates, os melhores que a estadia numa cidade que se pretendia fria poderia me oferecer. No final, eles já eram como irmãos que eu simplesmente "adquiri".

- Ao CNPq, pela concessão da bolsa de estudo que proporcionou a realização desta pesquisa;

- Por fim, a cada um dos paulistanos que cederam de seu tempo para a construção da amostra da fala paulistana. Quem disse mesmo que paulistano não para? Eles pararam por pelo menos uma hora, e fizeram o SP2010 acontecer. 


\section{Resumo}

Com base nos pressupostos teórico-metodológicos da Sociolinguística Variacionista (LABOV, 2008 [1972]; 2001), esta pesquisa investiga o emprego de formas verbais subjuntivas e indicativas em três contextos de subordinação - orações adverbiais, substantivas (na posição de complemento do verbo da oração principal) e relativas. Os dados foram extraídos de 36 entrevistas sociolinguísticas com paulistanos e 36 entrevistas com ludovicenses, estratificadas de acordo com o sexo/gênero dos informantes, sua faixa etária (18 a 35; 36 a 59; e 60 anos ou mais) e seu nivel de escolaridade (médio superior). Examinam-se as variáveis linguísticas e sociais que se correlacionam à ocorrência dessas formas. Entre as linguísticas, incluem-se variáveis como o tempo verbal da oração subordinada; o tipo de subordinador (tais como se e embora, no caso das orações adverbiais); o verbo da oração principal e o tempo verbal da oração principal (no caso das orações substantivas). Propõe-se que, em português, formas subjuntivas e indicativas funcionam como variantes de uma variável apenas nas orações adverbiais, ao passo que, nos outros dois contextos, tais formas se alternam mas não constituem sempre "formas de dizer a mesma coisa" (LABOV, 1972; 1978). A análise quantitativa dos dados foi feita com o pacote estatístico GoldVarb X (SANKOFF, TAGLIAMONTE, SMITH, 2005). Os resultados indicam que, no geral, é maior a tendência de ocorrência do modo indicativo em São Paulo relativamente a São Luís. Por outro lado, há indício de mudança na fala ludovicense, na direção do indicativo, em orações adverbiais e substantivas.

Palavras-chave: Modo subjuntivo. Modo Indicativo. Português paulistano. Português ludovicense. 


\begin{abstract}
Based on the theory and methods of Variationist Sociolinguistics (LABOV, 2008 [1972]; 2001), this master thesis investigates the use of indicative and subjunctive verbal forms in three contexts of subordination: adverbial, nominal and relative clauses. The data were extracted from 36 sociolinguistic interviews with native speakers from São Paulo and 36 from São Luís, stratified by sex/gender, age (18-35 years old, 36 to 59, and 60 or older) and level of education (high school or college). Social and linguistic independent variables are examined vis-à-vis their correlation to the occurrence of those forms. Among the linguistic factors are the verbal tense in the subordinate clause, the subordinator (as ' $s e$ ' if and 'embora' though, for adverbial clauses), the verb and the verb tense in the main clause (for the nominal clauses, embedded in the position of the verbal complement). This thesis discusses that, in Brazilian Portuguese, subjunctive and indicative forms function as variants of a variable in adverbial clauses, but not in nominal or relative clauses, in which they are not "different ways of saying the same thing" (Labov, 1972; 1978). The quantitative analyses were developed on GoldVarb X (SANKOFF, TAGLIAMONTE, SMITH, 2005). The results suggest that indicative forms tend to occur more in São Paulo - relatively to São Luís. However, there's change in progress in São Luís (apparent time), with the indicative being favored by younger speakers, both in adverbial and nominal subordinate clauses.
\end{abstract}

Keywords: Subjunctive. Indicative. São Paulo Portuguese. São Luís Portuguese. 


\section{Lista de Tabelas}

p.

TABELA 1 - Distribuição geral dos dados - São Paulo.............. 58

TABELA 2 - Distribuição geral dos dados - São Luís................ 58

TABELA 3 - Corpora utilizados por Santos (2012) .................. 62

TABELA 4 - Distribuição geral dos dados - São Paulo............... 80

TABELA 5 - Orações adverbiais e Fatores Sociais - São Paulo..... 81

TABELA 6 - Orações adverbiais e Fatores Linguísticos - São Paulo...................................................... 83

TABELA 7 - Frequências do Indicativo com outros subordinadores - São Paulo.............................. 84

TABELA 8 - Ordem de Orações no período e emprego do Indicativo

TABELA 9 - Fatores relevantes para a alternância indicativo/subjuntivo em subordinadas substantivas - São Paulo..................................

TABELA 10- Grupos de Fatores não selecionados nas análises das subordinadas substantivas - São Paulo........... 89

TABELA 11 - O indicativo em orações relativas - São Paulo.......... 91

TABELA 12 - Distribuição geral dos dados - São Luís................ 93

TABELA 13 - Orações adverbiais e Fatores Sociais - São Luís...... 94

TABELA 14 - Orações adverbiais e a Faixa Etária - São Luís........ 94

TABELA 15 - Orações adverbiais e Fatores Linguísticos - São Luís........................................................ 96

TABELA 16 - Tipo de subordinador VERSUS Tempo verbal da Oração Subordinada....................................... 97

TABELA 17 - Orações adverbiais e o Tipo de subordinador - São Luís (Tempo verbal da subordinada excluído)......... 97

TABELA 18 - Orações adverbiais e o Tempo verbal da oração subordinada e retirada do tipo de Subordinador São Luís.

TABELA 19 - Orações Substantivas e os Fatores Extralinguísticos 


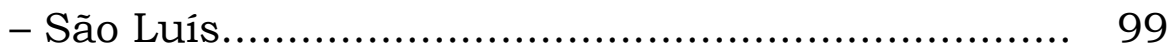

TABELA 20 - Orações Substantivas e os Grupos de Fatores Linguísticos - São Luís.................................... 102

TABELA 21 - Orações Relativas e Grupos de Fatores Sociais - São Luís.............................................................. 104

TABELA 22 - Orações Relativas e os Grupos de Fatores Linguísticos - São Luís......................................... 106

TABELA 23 - Análise Global com os Conjuntos de Dados e Cidade.......................................................... 109

TABELA 24 - Conjunto de Dados e Cidade................................. 110 


\section{Lista de Figuras}

FIGURA 1 - Tendência de emprego do Indicativo de acordo com a Faixa Etária - São Paulo

FIGURA 2 - Tendências de emprego do Indicativo e Faixa Etária - São Luís

FIGURA 3 - Frequência do Indicativo - São Paulo e São Luís....... 100

FIGURA 4 - Frequência do Indicativo por Faixa Etária - São Paulo e São Luís................................................... 104

FIGURA 5 - Tendência de emprego do Indicativo por conjunto de dados em São Paulo e São Luís

\section{Lista de Quadros}

QUADRO 1 - Perfis Sociolinguísticos da amostra......................... 51

QUADRO 2 - Informantes das subamostras paulistana e ludovicense..................................................... 54

QUADRO 3 - Grupos de Fatores Sociais................................. 58

QUADRO 4 - Grupos de Fatores Linguísticos............................ 60

QUADRO 5 - Grupos de Fatores Linguísticos para cada Conjunto de Dados.............................................................. 78 


\section{Sumário}

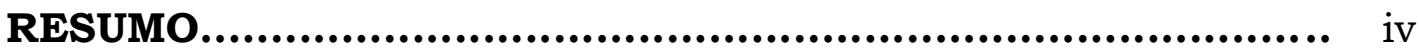

ABSTRACT........................................................... v

LISTA DE TABELAS............................................. vi

LISTA DE FIGURAS.............................................. vii

LISTA DE QUADROS............................................. vii

SUMÁRIO...................................................................... viii

INTRODUÇÃO.......................................................... 14

1. O SUBJUNTIVO COMO OBJETO DE ESTUDO..................... 21

1.1. O MODO SUBJUNTIVO EM OUTRAS LÍNGUAS................ 21

1.2. O SUBJUNTIVO EM PORTUGUÊS BRASILEIRO................ 32

1.3. ANÁlise VARIACIONISTA PARA ALÉM DO NÍVEL FONOLÓGICO................................................................ 38

2. CORPUS E MÉTODOS DA PESQUISA................................. 43

2.1. AS AMOSTRAS DE FALA PAULISTANA E LUDOVICENSE...... 48

2.1.1. A amostra paulistana....................................... 49

2.1.2. A amostra ludovicense...................................... 51

3. HIPÓTESES DE CORRELAÇÃO.................................... 56

3.1 HIPÓTESES SOCIAIS............................................. 61

3.1.1. Cidade de Origem............................................ 61

3.1.2. Sexo/Gênero...................................................... 61

3.1.3. Faixa Etária...................................................... 63 
3.1.4. Escolaridade.

3.2. HIPÓTESES LINGUÍSTICAS........................................ 65

3.2.1. Conjunto de Dados........................................ 65

3.2.2. Verbo da Oração Principal..................................... 67

3.2.3. Tempo Verbal da Oração Principal............................ 69

3.2.4. Tempo Verbal da Oração Subordinada....................... 70

3.2.5. Grau da Assertividade da Oração............................ 71

3.2.6. Distância entre o Pronome Relativo e a Forma Verbal em Foco......................................................... 73

3.2.7. Tipo de Subordinador....................................... 75

3.2.2. Ordem das Orações no Período Composto por Subordinação............................................... 77

4. ANÁLISES QUANTITATIVAS......................................... 79

4.1. A VARIEDADE PAULISTANA.................................... 80

4.1.1. Orações Adverbiais.......................................... 80

4.1.2. Orações Subordinadas Substantivas......................... 85

4.1.3. Orações Relativas.................................................. 90

4.2. A VARIEDADE LUDOVICENSE....................................... 92

4.2.1. Distribuição Geral dos Dados................................ 92

4.2.2. Orações Adverbiais.......................................... 93

4.2.3. Orações Subordinadas Substantivas......................... 98

4.2.4. Orações Relativas................................................... 103

4.3. ANÁLISE GLOBAL...................................................... 107 
Conclusões................................................................ 112

Referências........................................................................... 115

Anexos........................................................................... 122

Apêndices........................................................................... 139 


\section{INTRODUÇÃO}

O emprego do modo subjuntivo vem atraindo cada vez mais o interesse da linguística brasileira. Santos (2005), por exemplo, estudou a alternância entre os modos indicativo e subjuntivo em orações subordinadas substantivas e adverbiais a partir da análise de dados extraídos da fala de sujeitos nascidos em cidades do noroeste paulista ${ }^{1}$. Mais recentemente, Pimpão (2012) analisou casos em que a forma do presente do subjuntivo coocorre com a forma do presente do indicativo, na fala de sujeitos nascidos em Florianópolis e Lages. Esta autora também oferece uma análise diacrônica de dados extraídos de uma amostra composta por cartas publicadas em jornais locais (do século XIX até o fim do século XX).

Anteriormente a esses, há as pesquisas realizadas por Botelho Pereira (1974) e Wherritt (1977). A primeira analisa, de uma perspectiva semântica, sentenças subordinadas introduzidas por que $e^{2}$ enfoca a (a)gramaticalidade da substituição do modo subjuntivo pelo indicativo em certos contextos alternantes. Wherritt (1977), por sua vez, analisou a variação entre o subjuntivo e o indicativo, na fala de sujeitos de cidades paulistas (inclusive a capital), e aplicou de testes em que os informantes deveriam completar orações subordinadas substantivas, adjetivas e adverbiais.

\footnotetext{
${ }^{1}$ Santos (2005) analisa dados da fala de sujeitos entrevistados pelo Projeto Iboruna (cf. GONÇALVES, 2005), e que vivem na região noroeste paulista, mais especificamente nas cidades de São José do Rio Preto, Bady Bassit, Mirassol, Guapiaçu, Onda Verde, Cedral e Ipiguá.

2 Botelho Pereira (1974) realizou um teste de "percepção" entre 21 sujeitos com nível superior de escolaridade, cuja origem não é explicitada no texto, a fim de determinar em quais contextos a forma do indicativo poderia substituir a do subjuntivo, sem alteração semântica do enunciado.
} 
Com exceção de Botelho Pereira (1974), que analisa a possibilidade de variação entre o indicativo e o subjuntivo a partir de sentenças "intuídas" do português brasileiro, os outros trabalhos até aqui citados valem-se de dados reais, efetivamente empregados por informantes.

Além desses, outros trabalhos também analisam dados de fala para estudar a variação entre o subjuntivo e o indicativo. No contexto brasileiro, destacam-se ainda os trabalhos de Pimpão (1999), cujos dados foram coletados em Florianópolis, e Alves Neta (2000), cuja amostra foi coletada na cidade de Januária-MG.

O presente trabalho se insere entre essas pesquisas, na medida em que se objetiva verificar se há casos em que o modo subjuntivo pode ser expresso ainda que se empreguem formas verbais do indicativo. Para isso, analisam-se dados coletados em duas capitais - São Paulo (SP) e São Luís (MA). A justificativa para isso resiste no fato de que, na visão leiga, "paulistas não usam muito o subjuntivo", por um lado, e que "a ludovicense é a que mais guarda semelhanças com a variedade europeia do português" (cf. FREIRE, 2006; HONÓRIO DO COUTO, 1986; TRAVAGLIA, 2006) ${ }^{3}$. Nesse sentido, interessa verificar se há diferenças de taxas de emprego desses modos verbais em amostras de fala dessas cidades.

Entretanto, o exame de dados no sentido de "verificar se há casos em que o modo subjuntivo pode ser expresso ainda que se empreguem formas do indicativo" - o objetivo mais geral que se delineia acima - não é trivial. Em primeiro lugar, esta formulação em princípio pressupõe que a formas verbais (em termos de flexão mesmo) seriam variantes de uma variável. Tal proposição parece se verificar em alguns casos, como em:

\footnotetext{
${ }^{3}$ No capítulo 3 deste trabalho são dadas informações sobre as localidades estudadas,
} além de um detalhamento dessas duas afirmações. 
(1) D1: em relação a... a violência você já sofreu algum... ato de violência?

S1: nós automaticamente não se expõe à violência porque nós é muito família então não tem muito contato com isso [embora é uma coisa generalizada em São Paulo] (SPM2B-NelsonF.) ${ }^{4}$

(2) eu tenho facilidade de pegar o sotaque então [se eu vou... pra Minas] eu saio falando (amineirado). (SPF1S-SilviaB.)

(3) com o passar do tempo [talvez a gente acaba gostando mais da nossa mãe]... (SLM1S-EduardoE.)

Nesses três casos, as orações iniciadas com embora, se e talvez são analisadas como subordinadas adverbiais que, pelo seu traço semântico de irrealis (GIVÓN, 1984), em princípio requereriam o emprego do modo subjuntivo, ou da "morfologia 'própria' do modo subjuntivo" - conforme convém dizer aqui. A questão central, nestes casos ou contextos de subordinação, é que parece bastante defensável a proposição de que formas verbais do modo indicativo (estou, tinha, vou) podem figurar no lugar das formas verbais correlatas do modo subjuntivo (esteja, tivesse, vá). Ainda assim, dadas as estruturas de subordinação, bem como a "manutenção" do traço de irrealis nesses casos (apesar das formas verbais do indicativo e provavelmente graças aos termos embora, se e talvez), parece que a noção de subjuntividade se mantém. Em outras palavras, "modo subjuntivo" poderia ser entendido, aqui, como uma categoria mais abstrata, menos atrelada à morfologia verbal. Em outras palavras ainda, as formas verbais do indicativo e do subjuntivo seriam "formas de dizer a mesma coisa" (LABOV, 1972; 1978); ou seja, seriam formas variantes que constituem a variável "modo subjuntivo" (ou "subjuntividade").

\footnotetext{
4 Nos exemplos, D1 e $S 1$ referem-se, respectivamente, a Documentador e (Sujeito) Informante. Os códigos entre parênteses, logo após os trechos das entrevistas indicam a cidade do informante (São Paulo ou São Luís), o seu sexo/gênero (Masculino ou Feminino), a faixa etária (1, para informantes que estejam entre 18 e 35 anos; $\mathbf{2}$, para informantes que estejam entre 36 e 59 anos; e, 3, para informantes que estejam com 60 anos ou mais) e seu nivel de escolaridade (B, para aqueles que possuem até a educação básica, e $\mathbf{S}$, para os informantes que possuem ensino superior). Informações mais detalhadas sobre os informantes podem ser encontradas no capitulo 3.
} 
Como tal, viria ao caso aventar aquelas hipóteses caras aos trabalhos variacionistas - hipóteses essas que se traduzem em grupos de fatores (ou variáveis independentes) tanto de natureza social quanto linguística. No primeiro caso, uma pergunta que se colocaria é: será que nesses contextos de subordinação adverbial, a forma do indicativo tende a ser mais empregada a depender da localidade (neste trabalho, São Luís e São Paulo)? Em termos linguísticos, interessaria verificar se alguma dessas conjunções subordinativas (embora, se, talvez) favorecem ou desfavorecem o emprego de formas do indicativo no lugar das do subjuntivo. Além disso, seria interessante testar se o tempo verbal da oração guarda alguma correlação com a variável.

Entretanto, há outros casos de subordinação em que as formas do subjuntivo e indicativo se alternam, mas nos quais não parecem funcionar como variantes de uma variável:

(4) [eu acredito] [que ela vai se reeleger]

(5) meus pais sempre compravam os livro [que os professores indicassem].

Em (4) e (5), temos orações subordinadas iniciadas por que; no primeiro destes exemplos, a oração é substantiva e está encaixada (cf. KATO; TARALLO, 1993; MIRA MATEUS et al, 2003) na posição do objeto direto de acreditar; no segundo, a oração é adjetiva e relativa ao substantivo livro. Parece ser possivel alternar a forma do indicativo com a do subjuntivo nesses casos:

(4a) [eu acredito] [que ela vá se reeleger]

(5a) meus pais sempre compravam os livro [que os professores indicavam].

De fato, exemplos semelhantes foram encontrados nas amostras da fala paulistana e ludovicense: 
(6) nossa teve um dia que o meu marido passou super mal [eu pensava] [que ele ia morrer] naquele dia... (SPF3B-DarcyM.)

(7) sou cismada com qualquer pessoa que [encosta do meu lado] (SPF1B-MilenaF.)

Entretanto, para estes casos, a proposição de que as formas do indicativo e do subjuntivo funcionam como variantes de uma variável parece mais dificil de defender. Embora estejamos diante de estruturas de subordinação - o contexto típico do modo subjuntivo (cf. CÂMARA JR., 1986; BECHARA, 2005; MENDES DE ALMEIDA, 2005) - formas subjuntivas e indicativas não parecem figurar como formas de dizer a mesma coisa. Eu acredito que ela vá se reeleger parece veicular uma ideia de dúvida que não parece permanecer em Eu acredito que ela vai se reeleger. Em outras palavras, nestes casos, não se constituiria uma variável na relação forma-função: antes, a noção de subjuntividade se expressa com a forma própria do modo subjuntivo (vá), mas não com a forma do indicativo (vai).

Dessa forma, parece mais preciso referir-se a casos como estes como "contextos de alternância" de formas. Todos esses casos são mais detidamente discutidos no Capítulo 1, mas apesar da diferença entre os exemplos (1) a (3), de um lado, e os exemplo (4) a (7), de outro, permanece a pergunta mais geral, que interessa ao presente trabalho tanto quanto àqueles anteriormente citados: estariam as formas do indicativo "tomando espaços" das formas do subjuntivo?

No sentido de responder tal pergunta, este trabalho extraiu dados desses três casos de subordinação (adverbial, substantiva e adjetiva) de 36 entrevistas gravadas em São Luís (MA), com ludovicenses nativos, e 36 entrevistas do Projeto SP2010, com paulistanos nativos. Ainda que se argumente que variação de facto se observa apenas nos casos de subordinação adverbial, a técnica de análise quantitativa é variacionista (LABOV, 2006 [1966]; 2001; 2008 
[1972]) para os três conjuntos de dados - conforme se discute nos capítulos a seguir.

O capítulo 1 discute esses conjuntos de casos de subordinação em que formas do indicativo e subjuntivo funcionam ou como variantes de uma variável ou como formas alternantes em português - após apresentar uma breve discussão acerca do modo subjuntivo, da maneira como ele é expresso e tratado em outras línguas: o latim (cf. BLATT, 1952; MAURER JR, 1959), o inglês (cf. RIBAS, 2014), o alemão (cf. GATTI, 2004), o francês (cf. POPLACK, 1994; GRIMM, 2012), o italiano (cf. BARRA ROCHA, 1992).

O Capítulo 2 dedica-se a descrever as amostras coletadas em São Paulo e São Luís, aqui tomadas como "comunidades de fala" diferentes. Tal conceito laboviano é brevemente rediscutido, (LABOV, 2006 [1966]), a partir da descrição das duas comunidades em foco. Discutem-se também os grupos de fatores sociais incluídos nas análises, a partir da descrição da estratificação das duas amostras de fala.

$\mathrm{Na}$ sequência, o Capítulo 3 oferece as distribuições gerais de ocorrências de formas do indicativo e do subjuntivo, por conjunto de dados (subordinadas adverbiais, substantivas e adjetivas) e por capital. É neste ponto que se apresentam os grupos de fatores linguísticos incluídos nas análises, estabelecidos a partir de hipóteses de correlação com o emprego (variável ou alternante) das formas do indicativo e do subjuntivo.

Finalmente, o Capítulo 4 discute os resultados das análises quantitativas dos dados, com foco sobretudo nos grupos de fatores (sociais e linguísticos) que se revelaram estatisticamente significativos nos casos de variação e de alternância de formas. Além das análises de cada um dos três conjuntos de dados separadamente, desenvolve-se 
uma análise em que se amalgamam todos eles, no sentido de verificar se, estatisticamente, São Paulo e São Luís se diferenciam de fato no emprego de formas do indicativo e do subjuntivo - em outras palavras, se uma ou outra forma é favorecida na fala de falantes de uma ou de outra cidade. 


\section{CAPÍtulo 1 \\ O SUBJUNTIVO COMO OBJETO DE ESTUDO}

Este capítulo apresenta uma discussão acerca de noções semânticas e pragmáticas de interesse para os conceitos de modo subjuntivo e subjuntividade, bem como irrealis - um traço que se associa diretamente à atitude de julgamento, por parte dos falantes, de uma verdade possivel (cf. GIVON, 1984, 1995, 2001). Discute-se como a subjuntividade se expressa e como o modo subjuntivo se codifica em diferentes línguas, no intuito de chegar a uma proposta de análise - no português falado no Brasil - de contextos em que formas verbais subjuntivas e indicativas são alternativamente empregadas. Conforme adiantou-se na Introdução, os dados do português analisados nesta dissertação foram recolhidos em duas capitais - São Paulo e São Luís. Recorre-se a estudos que tenham buscado compreender a expressão do subjuntivo em outras línguas neolatinas, como o italiano, o espanhol e o francês (cf. BARRA ROCHA, 1992; POPLACK, POUSADA, 1981; POPLACK, 1990, 1994; GRIMM, 2012), além do inglês (cf. RIBAS, 2014) e do alemão (cf. GATTI, 2004).

\subsection{O MODO SUBJUNTIVO EM OUTRAS LÍNGUAS}

A questão da oposição entre o subjuntivo e o indicativo nos usos do português pode ser definida a partir do enfoque dado a esses dois modos verbais.

Segundo Cunha (1985), o modo subjuntivo denota uma ação ainda não realizada, dependente de outra ação, expressa ou subentendida. Além disso, o modo subjuntivo é aquele que indica ordem, proibição, desejo, vontade. Se os modos verbais são em geral definidos a partir da posição do falante diante da relação entre uma ação e seu agente, o modo subjuntivo faz referência aos fatos incertos da lingua (cf. BECHARA, 2005). 
No entanto, Blatt (1952) verificou que, já no latim clássico, havia a possibilidade de alternância entre esses dois modos. De acordo com o autor, as formas do subjuntivo e do indicativo não são, desde aquela época, bem definidas. Para ele, as noções de deliberação e de dúvida, características próprias do subjuntivo, podem também ser expressas pelo indicativo, e a noção de irrealis pode ser traduzida, em certos casos, por esse modo verbal.

Para exemplificar as possibilidades de substituição do subjuntivo pelo indicativo já no latim, Ernesto Faria (1958: 228) apresenta dois excertos extraídos da obra De Platone et eius dogmate (de Apuleio) em que a conjunção latina quando introduz sentenças subordinadas cujo verbo encontra-se com as duas morfologias modais.

(8) Non enim eam contumeliam putat, quam inprobus faciat, set eam non putat, quam patientia firmiter toleret, quando quidem naturae lege in animo eius sculptum sit quod nihil horum possit nocere sapienti, quae opinantur ceteri mala esse. (Apuleio, De Platone et eius dogmate, Liber secundus, XX. Grifos de Ernesto Faria)

'Pois ele não considera um ultraje o ato que um homem desonesto venha cometer, mas aquele que sua resistência lhe permite suportar com firmeza, quando fosse gravado em sua alma pela lei da natureza que nada disto pudesse prejudicar o sábio, coisas que outros consideram ser mau'.

(9) Pari pacto et eorum quae declinanda sunt, quaedam omnibus ac semper uideri mala, quando nocent atque obsunt, ut sunt uitia et infortunia, quaedam aliis nec ea semper nocere, ut aegritudinem, egestatem et cetera. (Apuleio, De Platone et eius dogmate, Líber secundus, X.)

'Do mesmo modo também, entre os males a afastar, alguns, segundo ele aparecem tais aos olhos de todos e sempre, quando são nocivos e contrários, como os vícios e os infortúnios, alguns só prejudicariam a uns, mas nem sempre, como a doença, a indigência e o resto'5.

Os exemplos em (8) e (9) são evidências de que já se verificava alternância entre os modos indicativo e subjuntivo no latim.

\footnotetext{
${ }^{5}$ As traduções e os grifos dos exemplos 8 e 9 são de Ernesto Faria.
} 
De acordo com o que ensina Ernesto Faria (1958), a conjunção subordinativa quando é, desde os tempos do latim clássico, própria para introduzir orações subordinadas no indicativo. Entretanto, reconhece que muitos autores, a exemplo de Apuleio, utilizavam a forma do subjuntivo levados pelas imposições normativas.

O autor sugere que o uso da forma do subjuntivo em (8) quando quidem 'quando fosse' - parece estar associada a expressão de algo que é irreal. De qualquer modo, ele entende que a mesma intenção é reportada em (9), na estrutura quando atque 'quando são', ainda que expressa com morfologia do indicativo. Faria (1958: 228) explica que “[...] esse tipo de oração causal que poderia confundir-se com a oração temporal, referencia uma prática uma prática habitual no registro comercial, e, portanto, de hábito cristalizado, paasa a constituir uma causa". Desse modo, esse hábito cristalizado de que trata o autor, encontraria reflexos nos usos não definidos das formas subjuntivas e indicativas no latim.

Blatt (1952) sugere que, diacronicamente, o subjuntivo passou a ser estreitamente correlacionado com estruturas de subordinação, e que essa "afinidade" foi tomada e prescrita pela norma culta como "a correta". De certa forma, as traduções acima indicam que a noção de verdade possivel pode ser expressa tanto por formas do modo subjuntivo quanto por formas correlatas do indicativo. Ele explica que a marca morfológica da modalidade subjuntiva revela uma atitude "de dúvida" do falante em relação ao seu enunciado. Dessa forma, observase que se a formado indicativo já apresentava motivação nas expressões de causa no latim, os dados eram tidos como certos por aqueles falantes, enquanto que o uso da forma do subjuntivo marcava a expressão de algo possivel, uma suposição, o que justificava o uso da forma desse modo verbal. 
Maurer Junior (1959: 194) menciona o fato de que o subjuntivo vem desde o latim vulgar perdendo alguns dos seus tempos e restringindo a sua função. O autor explica que o condicional "é um modo de criação românica", empregado em diversos contextos da România Ocidental com valor de "[...] passado do futuro imperfeito do subjuntivo; na apódose do período hipotético; como modo de dúvida; e com valor de subjuntivo potencial latino na segunda pessoa do plural", para exprimir uma espécie de “impessoal”. Desse modo, acrescenta o autor, "o condicional vai "desenvolvendo o seu emprego modal (...) entrando em concorrência com o subjuntivo" (p. 199). O autor explica que isso se dava principalmente porque, de um lado, o povo, que usava mais o indicativo, destinava o subjuntivo apenas à possibilidade de expressar dúvidas, enquanto que os semieruditos, de outro, se esforçavam por atribuir um caráter literário às suas proposições.

Esta espécie de "convergência" de formas do subjuntivo e do indicativo em certos contextos - que se verificou acima com exemplos do latim, bem como na relação entre erudição e emprego do subjuntivo - ainda parece se observar atualmente em certas linguas românicas tais como o italiano, o espanhol e o francês - nas quais são vários os contextos em que o indicativo é empregado quando, em princípio, a gramática normativa prescreve o subjuntivo.

Barra Rocha (1992) explica que, em italiano, o modo subjuntivo apresenta quatro tempos verbais (presente, passado, imperfeito e maisque-perfeito) e que, diferentemente do português, não possui os tempos futuro simples e futuro composto do subjuntivo6. Além disso, a autora mostra que há semelhanças entre a $2^{\mathrm{a}}$ pessoa do singular de verbos da

\footnotetext{
${ }^{6}$ Para Barra Rocha (1992: 46), de acordo com o que ensinam os manuais para ensino da língua italiana, a falta desses dois tempos verbais "seria suprida pelo futuro (futuro imperfeito, futuro simples ou ainda futuro do presente) do indicativo ou pelo presente do indicativo". Assim, para se puder, irei para casa mais cedo, em italiano são possíveis Se potrò, andrò a casa più presto, no futuro, ou Se posso, vado a casa più presto, no presente.
} 
$1^{\text {a }}$ conjugação no presente do indicativo e do presente do subjuntivo, como em tu parli 'você fala' e che tu parli 'que você fale', bem como entre a $1^{\text {a }}$ pessoa do plural do presente do indicativo e do presente do subjuntivo das três conjugações, como em noi parliamo/che noi parliamo; noi prendiamo/che noi prendiamo; noi partiamo/che noi partiamo.

Assim como em português, a tradição gramatical italiana também considera que o subjuntivo é o modo das incertezas, dúvidas e possibilidades, e que nem sempre é a morfologia do verbo da oração subordinada que traduz essas noções. Nas palavras de Barra Rocha (1992:49), "[...] é o conteúdo semântico das palavras que compõem os enunciados, e, ainda, certos fatores sintáticos" que contribuem para a expressão do modo subjuntivo. Esses itens lexicais seriam advérbios como forse 'talvez', locuções como mio parere 'segundo meu parecer' no caso de orações adverbiais -, e expressões verbais tais como mi pare che 'me parece que', e os verbos potere 'poder' e dovere 'dever'. A autora também indica que verbos como volere 'querer' e desiderare 'desejar' regem verbos (na oração subordinada) tanto no indicativo quanto no subjuntivo.

(10) Max vuole che tu te ne vai.

'Max quer que você vai embora'.

(11) Max vuole che tu te ne vada.

'Max quer que você vá embora'

Para casos como esses em (9) e (10), Barra Rocha (1992) sugere que as diferenças entre os modos, no italiano, dependem mais de agrupamentos sintáticos do que de fatores semânticos. Parece ser este o caso também no espanhol. Poplack e Pousada (1981) analisaram o espanhol falado por estudantes porto-riquenhos instalados na cidade de Los Angeles, nos Estados Unidos, e verificaram que, diferentemente do que recomendam as gramáticas normativas daquela língua, o

\footnotetext{
7 Traduções de Barra Rocha (1992: 53).
} 
subjuntivo e o indicativo podem ambos ocorrer diante de verbos que indiquem desejo ou necessidade (querer e ordenar), sentimentos (gostar e preferir), bem como com expressões que atribuem juízo de valor diante do que é dito, a exemplo das ocorrências de (10) a (13) a seguir.

(12) Juan há dicho que viene, aunque tiene clases.

'Juan disse que vem, ainda que ele tem aulas'.

(13) Ayer mi madre dijo que aunque tenga que salir temprano, no saldrá.

'Ontem minha mãe disse que ainda que tenha que sair cedo, não sairá.'

(14) Si tenía dieciocho años, podría manejar.

'Se tinha dezoito anos, poderia dirigir.'

(15) Si el clima ayudara, viajaríamos mañana.

'Se o clima ajudasse, viajariamos amanhã.'

Silva-Corvalán (1981) verificou que os padrões de uso do subjuntivo mudaram no espanhol, já que o indicativo tem sido cada vez mais usado em contextos em que o subjuntivo seria "recomendado" e, assim como no italiano, outros elementos presentes na sentença contribuem para que a noção de subjuntividade seja expressa, tais como advérbios e locuções adverbiais.

A respeito do francês, Poplack (1990) analisou o emprego do modo subjuntivo numa amostra de 120 francofones nativos do Canadá, residentes da região bilingue de Ottawa-Hull. Ao focalizar orações subordinadas substantivas, a autora levou em consideração contextos em que o modo selecionado "deveria" ser o subjuntivo e aqueles nos quais efetivamente ocorre. Ela parte da crítica à gramática normativa da língua francesa, que prevê o uso do subjuntivo na oração subordinada, a partir da exigência do verbo na oração principal ${ }^{8}$.

8 Segundo Poplack (1990), o modo nada mais seria do que uma marca redundante da subordinação sintática. Contudo, a autora não desconsidera a relação entre o verbo 
Poplack (1990) observou que o verbo principal impessoal falloir 'ser necessário que'9 se comportava diferentemente de outros verbos: os resultados apontam para uma forte associação desse verbo com a forma do subjuntivo. Além disso, a autora verificou que há uma forte correlação entre a semântica do verbo da oração principal e o modo verbal selecionado na oração subordinada.

(16) Mais j'espere que je serais (C) capable de passer... a travers. 'Mas eu espero que eu seria capaz de ir até o fim.' 10

A autora verificou que, diferentemente do que se observa para falloir, com os demais verbos, sua classe semântica (volitivos, emotivos e opinativos $^{11}$ ) favorece, em sua amostra, a seleção do modo indicativo, tal como o tempo presente (do verbo da oração principal). Seus resultados também indicam que a presença da partícula que favorece o emprego do modo subjuntivo. Entretanto, a autora reconhece que é necessário que se realize uma análise em que não se considere o verbo falloir, ou que ele seja considerado em análises em que esteja separado dos outros verbos da amostra.

Em outro estudo com dados de língua francesa - mas coletados da fala de canadenses da provincia de Ontario (que é predominantemente anglofone), Grimm (2012) observou que o modo subjuntivo aparece sem nenhuma prescrição aparente: é favorecido por

principal e a oração subordinada, acrescentando que certos elementos (como o grau de afirmação da oração subordinada, a presença de indicadores lexicais de modalidade, além do tempo verbal e a concordância do tempo verbal na oração principal) podem operar como fatores que contribuem para a escolha do modo verbal.

9 Tradução nossa.

10 Exemplo extraído de Poplack (1990). Tradução nossa.

11 Segundo Poplack (1990:PAGINA), a classe dos verbos denominados volitivos e emotivos é considerada pelos prescritivistas como as classes que exigem o subjuntivo em todos os contextos ('subjuntivo primário'), enquanto que os verbos denominados opinativos são aqueles que exigem o subjuntivo somente nas orações não afirmativas ('subjuntivos secundários'). 
falloir, em orações encaixadas/subordinadas, mas também em orações principais com outros verbos ${ }^{12}$, diferentemente do que verificou Poplack (1990). Por outro lado, de acordo com o autor, seus resultados sugerem que o modo subjuntivo vem perdendo produtividade na comunidade que focalizou.

Até aqui, vimos exemplos de (i) línguas em que há um paradigma verbal específico para tempos do modo subjuntivo e (ii) que há contextos em que formas do indicativo podem ocorrer quando se espera ou se prescreve o subjuntivo. Há línguas, contudo, que não dispõem de um paradigma flexional específico para o modo subjuntivo - como o inglês e o alemão. No entanto, isso não significa que essas línguas não expressem subjuntividade - que, conforme mostram Ribas (2014) e Gatti (2004), nessas línguas está mais associada aos tipos de orações do que à conjugação verbal ${ }^{13}$.

(17) Maybe he will buy more brown sugar in the afternoon.

'Talvez ele vá/vai comprar mais açúcar mascavo à tarde.' ${ }^{14}$

Nesse caso, will buy é a forma verbal do simple future no modo indicativo. Nesta oração, a expressão de uma possibilidade, de sua incerteza - características próprias do subjuntivo - se dá por meio do advérbio maybe 'talvez'.

$\mathrm{Na}$ expressão do "condicional", há casos em inglês em que se alternam formas da conjugação do verbo be 'ser, estar' como item adicional à conjunção if 'se', no sentido de expressar a noção de uma verdade possivel (cf. QUIRK; GREENBAUM, 1987):

12 Como exemplos, Grimm (2012) cita être (ser, estar) em contextos de expressão de emoção e de opinião, e supposer (supor), em contextos de expressão de possibilidade, como em 'Fraudait ça serait que'que chose à trancher'.

13 Gatti (2004) explica que, para o alemão, existe a ocorrência do morfema <e> como em sag-e-st 'dizer', que marca a oposição entre o subjuntivo e o indicativo. No entanto, acrescenta, esse "marcador" não ocorre na lingua falada.

${ }^{14}$ Exemplo extraído de Ribas (2014:77). Tradução nossa 
(18) If I were you, I wouldn't go.

'Se eu fosse você, eu não iria'.

(19)If there were enough time, we could go there.

'Se houvesse tempo suficiente, poderiamos ir lá'15.

Entretanto, ainda que a forma were (forma plural) seja empregada no lugar de was (forma singular correlata), seria impreciso dizer que estamos diante de um paradigma conjugacional próprio do modo subjuntivo: as formas pretéritas was/were são, a rigor, formas do modo indicativo. Mais interessante, contudo, é que também no inglês, neste contexto em que se "recomenda" a substituição de was por were, há variação nos usos, sobretudo em casos como (14a) - certamente com o mesmo significado de (14) acima:

(19a) If there was enough time, we could go there.

Os exemplos de (15) a (17) dão a entender de que modo a noção de irrealis é expressa em língua como inglês, que não possuem uma flexão modo-temporal para o subjuntivo. Ribas (2014: 69), apoiado em Downing \& Locke (2006), explica que

[...] o modo na língua inglesa está mais relacionado ao tipo das orações que ao modo, uma das razões é o fato de, nessa lingua, praticamente não haver marcação desinencial nos tempos verbais, inclusive no subjuntivo, fazendo com que as ideias representadas pelas modalidades sejam demonstradas por expressões, como maybe e If. (grifos originais)

Dessa forma, há línguas que dispõem “apenas” de elementos não verbo-flexionais para expressar essas noções. De qualquer modo, todas as línguas devem poder expressar verdades possiveis, incertezas, possibilidade, ainda que não disponham de um paradigma conjugacional próprio para isso. De acordo com Bybee (1998), esses fatos de forma (em que se incluem a morfologia verbal tanto quanto

\footnotetext{
15 Exemplos e traduções nossas.
} 
outros itens que participem de uma oração, tais como advérbios) relacionam-se ao amplo domínio conceitual da modalidade, que diz respeito à intenção de realidade ou irrealidade dos fatos - ou, em outras palavras, realis ou irrealis (cf. BYBEE, 1998:181).

Uma asserção com o traço realis apresenta uma proposição fortemente marcada como verdadeira, cujo falante possui evidências para aquilo que fala. Diferentemente, uma asserção com o traço irrealis apresenta uma proposição fracamente expressa. De qualquer modo, nenhuma das duas asserções possuem um elemento mórfico "obrigatório" que as expressem na oração.

Destarte, o conceito de irrealis confunde-se com o de subjuntividade. Entretanto, entende-se que o primeiro termo remete a uma noção mais abstrata (segundo a qual uma proposição é dada como incerta, duvidosa, provável - de acordo com Givón, 1995), enquanto que o segundo pode remeter mais imediatamente a um paradigma conjugacional específico - o do modo subjuntivo - sobretudo naquelas línguas que apresentam tal paradigma e, consequentemente, uma metalinguagem para fazer referência a ele. Além disso, convém ressaltar que, enquanto noção semântica mais abstrata, parece defensável que irrealis é algo que qualquer língua codifica, com os elementos de que dispuser, graças à sua história (portanto, ainda que morfologia verbal própria para o modo subjuntivo não seja um desses elementos).

Com base nessa argumentação, e apesar da discussão acima, o presente trabalho emprega indistintamente os termos "subjuntividade" e "irrealis" para fazer referência às noções afins a uma verdade possivel (embora às vezes prefira-se o segundo ao primeiro desses termos). Por outro lado, quando empregar o termo "modo subjuntivo", este trabalho estará doravante referindo-se especificamente à morfologia verbal - do português, língua que de fato enfoca. Entretanto, no sentido de expressar mais precisamente esta distinção - modo subjuntivo, de um 
lado; subjuntividade/irrealis, de outro - por vezes prefere-se o termo "morfologia subjuntiva" a modo subjuntivo.

Essas decisões se coadunam à consideração de que, ao observar exemplos de diferentes línguas, em que se verifica a possibilidade de alternância entre formas indicativas e subjuntivas em certos contextos, parece interessante propor que a noção de subjuntividade é “composicional” - no sentido de Comrie (1976) e Verkuyl (1993; 1999), que tratam não do modo, mas do aspecto (apud MENDES, 2005). O conceito de composicionalidade do aspecto reside, entre outros fatos, no de que, em muitas línguas, não há morfologia própria para os diferentes aspectos verbais - que se definem com vários elementos de uma oração. ${ }^{16}$ Em outras palavras, a relação entre forma e função pode não ser biunivoca: a noção de subjuntividade (função) pode ser expressa ainda que se "falhe" em empregar a morfologia (forma) própria do modo subjuntivo

(20) D1: quanto tempo você demora pra...

$\mathrm{S} 1 \mathrm{~d}$ duas horas [se eu fosse pegar transporte] [eu demoro duas horas...] é assim... como eu moro aqui/ como eu trabalho aqui eu tenho que pegar um ônibus... até Pinheiros... (SPM1B-NicolauS)

(21) S1: [se ele não era meu amigo mesmo] [ele não teria falado comigo]... eu acho... (SLM3S-AndresonR.)

(22) S1: mas [é uma amizade mais intensa] [embora tem menos tempol (SLM2B-Ronaldo)

(23) S1: [embora eu more no outro bairro] [eu jogo no time da onde que eu cresci] (SPM2B-NelsonF.)

(24) S1: nunca durou muito tempo meus comportamentos estereotipados assim de ah cara estudioso

16 De acordo com Mendes (2005), a expressão do aspecto iterativo em português brasileiro, por exemplo, pode se compor com a perífrase estar + gerúndio e certos adjuntos adverbiais, como em Está ficando doente muitas vezes nos últimos tempos. Para o autor, "está ficando doente" (fora de contexto e sem os adjuntos adverbiais que ajudam na composição da ideia de repetição ao longo do tempo) é uma oração ambigua do ponto de vista aspectual, ainda que possa ser mais imediatamente interpretada como progressiva (e não iterativa). 
D1: aquela primeira visão ah ele é comportado daqui a pouco... acabava rapidinho não era nunca

S1: não sei eh [talvez eu tenho transtorno de comportamento] (SLM1S-EduardoE.)

(25) D1: que que tem de ruim no paulistano

S1: não sei se tem um ufanismo eu acho que tem outros outros lugares que o pessoal é mais bairrista eu não... sei se o paulistano é... bairrista assim... eh de ruim... não sei [talvez seja muita falta de educação no trânsito...] isso é péssimo (SPM3BRodolfoR)

Os pares de exemplos acima (20 e 21; 22 e 23; 24 e 25) ilustram o fato de que a noção de subjuntividade/irrealis pode se dar em detrimento do emprego de uma morfologia verbal específica na oração subordinada. Isso se observa graças à "composicionalidade" (termo aqui emprestado de estudos sobre o aspecto verbal) da noção de subjuntividade - de que participam advérbios como embora, talvez, e a conjunção subordinativa se.

Nesses casos, as morfologias verbais podem, então, ser consideradas "formas variantes". Entretanto, há contextos em que o fato da variação - formas diferentes de dizer uma mesma coisa (Labov, 1972 ; 1978) - não se observa da mesma maneira. O item a seguir passa a discutir esses contextos.

\subsection{O SUBJUNTIVO EM PORTUGUÊS BRASILEIRO}

A sociolinguística variacionista estuda a lingua em uso numa comunidade de falantes. Tal comunidade compartilha normas tanto no que diz respeito ao emprego variável de formas, quanto no que concerne às atitudes sociais diante dessas formas. Neste trabalho, interessa pesquisar quais são os fatores - linguísticos e sociais - que se correlacionam ao emprego de formas subjuntivas ou indicativas, nos contextos em que ambas são possiveis. 
Entretanto, o conceito de correlação (quantitativamente testada) - entre uma variável dependente e variáveis independentes (os grupos de fatores linguísticos e sociais) - se aplica justamente quando se está diante de formas diferentes de dizer a mesma coisa (cf. LABOV, 1972; 1978). Conforme vimos acima, com os pares de exemplos (20 e 21), (22 e 23) e (24 e 25), este parece ser o caso das orações subordinadas adverbiais com se, embora e talvez, em que formas verbais subjuntivas e indicativas podem, variavelmente, contribuir para a composição do significado de subjuntividade - de acordo com a discussão desenvolvida na seção anterior. Vejam-se abaixo outros casos em que, de maneira semelhante aos pares de exemplos já apresentados, o subjuntivo e o indicativo parecem funcionar, nos usos, como formas variantes de uma variável:

(26) eu cuido da minha mãe [mesmo que minha mãe não me deu nada na vida] entendeu (SPM1B-NicolauS.)

(27) qualquer lugar que eu for eu prefiro ir de metrô [mesmo que seja pra pegar um... ficar fazendo baldeação] de um pro outro (SPM3B-RodolfoR.)

(28) a Constituição me garante o direito de me manifestar [desde que não use de anonimato] e eu posso expressar meu desapontamento com ela enquanto governadora (SLM2S-PedroH.)

(29) mas [desde que isso é um propósito pra ti] tu arrumas o teu parceiro e casa com ele (SLF3BDayseR.)

(30) [não é que as crianças sejam mal educadas] mas é porque mudou os valores (SLM1S-EduardoE.)

(31) [não é que eu não quero deixar elas fazerem] mas é tão automático a pessoa vem me dá o boleto me dá a apostila pede o negócio e assim já (es)tá tão automático (SPM1B-EvandroO.)

Evidentemente, há outros contextos em que subjuntivo e indicativo figuram como formas alternativas. Assim como nos dados do espanhol analisados por Poplack e Pousada (1981), orações 
substantivas encaixadas na posição de complemento de certos verbos constituem-se, também em português, como tais contextos:

(32) S1: pra lá de Campinas né não sei [acho] [que seja Jundiaí] eu não sei... (SPM1B-NicolauS).

(33) S1: é maravilhoso o lugar onde eu moro... tranquilo... não tem vizinhança... a vizinha assim é como... sabe... anda [acho] [que $\underline{e}$ dois metro] ... (SPM1B-NicolauS)

(34) S1: este povo perde tudo e se reergue pra perder tudo outra vez... então eles têm uma força de vontade e uma fibra muito grande... então [eles acreditam] [que alguém vai cuidar] deles no futuro... (SPM3S-NiltonR.)

(35) S1: esse professor que eu estava falando pra ti com quem [eu acredito] [que eu vá fazer doutorado full nos Estados Unidos] me disse uma vez que as oportunidades a gente sempre tem... (SLM1SEduardoE.)

(36) D1: e o que você acha de a mulher sair pra trabalhar e o homem ficar em casa fazendo as tarefas?

S1: se for pra acontecer isso se for né que [eu não quero] [que isso aconteça] mas que seja o homem trabalhando e a mulher em casa (SLM1S-LucioG.)

(37) [eu não quero] que ninguém fala do meu trabalho] e diz que eu não sei fazer (SPF2B-PamelaR.)

(38) D1: e a senhora queria que a sua filha visitasse mais a senhora? S1: ah eu queria né mas eu sei que ela foi pra buscar as melhora dela né... mas uma mãe sempre quer seus filhos mais perto [eu queria] [que a minha filha viesse mais]... (SLF3B-GrazielaD.)

(39) S1: eu cuidava de uma senhora... é que eu sou técnica em enfermagem né... aí a filha dessa senhora que eu cuidava [ela queria] [que eu vinha toda noite cuidar da velha] aí eu disse que era muito puxado assim... mito ruim né toda noite... (SLF2BAdalbertaC.)

Verbos como achar (32 e 33) e acreditar (34 e 35), na oração principal, parecem remeter a uma verdade possivel (no sentido de irrealis - "não realidade"). Nesse sentido, a despeito da diferença entre essas estruturas de subordinação e aquelas das orações adverbiais, o 
caráter de "dúvida" veiculado por esses dois verbos poderia ser tomado como argumento a favor de que a noção de subjuntividade/irrealis do período se manteria qualquer que fosse a forma verbal da subordinada (subjuntiva ou indicativa).

Por outro lado, há verbos que não veiculam propriamente a noção de dúvida ou incerteza, mas sim desejo - como é um caso do verbo volitivo (HOPPER E THOMPSON, 1980; GIVÓN, 1995) querer, os pares $(36 / 37)$ e $(38 / 39)$. Embora poderia fazer sentido propor que um desejo também remete a uma realidade possivel, há uma diferença semântica entre estes dois últimos pares e aqueles exemplos com achar e acreditar. Além disso, há uma diferença entre os próprios pares com querer: no presente (36/37), esse verbo parece remeter menos fortemente a uma "verdade possivel" do que no pretérito imperfeito (38/39). Em outras palavras, está-se aventando a hipótese de que quero que possivelmente favoreça o emprego do indicativo na subordinada, enquanto que queria que parece favorecer o emprego do subjuntivo.

É claro que tal hipótese precisa ser testada, mas o ponto fundamental aqui é que estes casos de subordinação a um verbo parecem funcionar - no que diz respeito à alternância entre formas indicativas e subjuntivas - de maneira diferente daquelas estruturas de subordinação adverbial que vimos anteriormente. Ainda que se possa argumentar no sentido de que, em alguns casos (como naqueles em 32 a 35, com achar e acreditar), haja semelhanças semânticas entre estruturas de subordinação adverbial e substantiva, propõe-se aqui que esses conjuntos de dados sejam analisados separadamente, sobretudo com base num critério estrutural.

Adicione-se a tal critério o fato de que, em alguns casos, parece mais difícil afirmar que as formas subjuntivas e indicativas - na oração subordinada que figura na posição de complemento do verbo principal signifiquem a mesma coisa. Eu não quero que isso aconteça (36) e Eu 
não quero que ninguém fala do meu trabalho (37) parecem mais diferentes entre si do que Queria que a minha filha viesse (38) e Ela queria que eu vinha toda noite cuidar da velha (39). Em outras palavras, há muitas nuanças semânticas neste conjunto de exemplos - de modo que o critério sintático parece mais "estável”, no sentido de se proponha que tais dados sejam analisados separadamente, em relação àqueles de subordinação adverbial.

Considerem-se ainda os seguintes exemplos:

(40) S1: vixe, antes de inventar esse tal de pole dance que eu não sabia nem o que era não tem aquele ferro da bandeira da escola? D1: aham.

S1: eu fazia altas manobras em cima daquele ferro mas [eu nunca imaginei] [que aquilo era pole dance]. (SLF1B-MariaF).

(41) S1: [suponhamos] [que você veio com dez anos do de Curitiba... ] e está aqui já há vinte aí não sei a pessoa se adapta aqui à cidade né. (SPM3B-RodolfoR).

Formas subjuntivas e indicativas parecem possiveis nas orações subordinadas em (38) e (39). Entretanto, não parece que imaginei que aquilo era pole dance significa a mesma coisa que imaginei que aquilo fosse pole dance; da mesma forma que não parece que suponhamos que você veio com 10 anos de Curitiba significa a mesma coisa que suponhamos que você viesse com 10 anos de Curitiba. Em razão de todos esses argumentos, sugere-se que, nestes contextos de subordinação substantiva (em que a oração subordinada está encaixada na posição do objeto direto do verbo da oração principal), observa-se, mais precisamente, alternância de modos - e não variação propriamente, entre formas verbais (embora argumentos contrários a isto possam ser desenvolvidos - assim como se fez aqui para os casos com achar e acreditar, mais acima).

Há ainda um terceiro conjunto de dados de subordinação em que se observa alternância entre formas verbais subjuntivas e 
indicativas. Trata-se das orações relativas, que se ligam a um nome anteriormente enunciado:

(42) S1: mais pra frente eu pretendo morar num condominio (...) [que tem um pouco mais de segurança]. (SLF3S-ElisangelaS.)

(43) D1: E tu já andaste a cavalo?

S1: Sim agora eu fui andar de cavalo e caí de cavalo literalmente andar de cavalo é uma coisa [que a gente olhe assim], acha tão fácil mas não é (SLM2S-AdrianoP.)

(44) S1: eu só faço aquilo que faz bem pra mim eu não vou fazer uma coisa [que faz mal pra mim] entendeu... (SPM1B-NicolauS)

(45) S1: já sai não assim daquele jeito igual Sabrina Sato 'aberta' mas... né mas sai mais assim mas lendo algum trecho [que as pessoas precisam entender] que eu né faço muita leitura lá né na na na da da da Bíblia aquele negócio né... (SPM3B-RodolfoR).

(46) S1: não tem gente [que ande de porsche] na Freguesia do Ó... mas tem gente [que anda de porsche] no Jardins... (SPM1SGuilhermeV.)

Nos exemplos (42) a (46), há uma semelhança estrutural com as orações encaixadas no lugar sintático do objeto direto, que é a presença do conector que. Nesses casos de orações relativas (que se adjungem a um nome), contudo, parece ainda mais dificil propor que formas subjuntivas e indicativas significam a mesma coisa. No último dos exemplos acima, que ande/anda de Porsche é uma oração que se relaciona ao substantivo gente e, a despeito do paralelismo entre as duas estruturas de subordinação que aparecem no exemplo - de fato, as duas estruturas são praticamente idênticas, de um ponto de vista sintático - ande remete a uma possibilidade (que se pode parafrasear assim: embora possivel, é inimaginável a ocorrência de um Porsche nas ruas da Freguesia do Ó, um bairro considerado periférico na capital paulista). Por outro lado, em tem gente que anda de Porsche no Jardins, já não estamos no domínio modal de irrealis. Entretanto, é interessante observar que, no primeiro período, a oração principal é negativa, e o segundo período é ligado ao primeiro por uma adversativa mas (ou seja: 
não tem gente que ande de Porsche na Freguesia opõe-se, semanticamente, a mas tem gente que anda de Porsche nos Jardins).

É verdade que este último exemplo poderia ser reformulado, com indicativo no lugar da forma subjuntiva, e com subjuntivo no lugar da forma indicativa - tal como se faz abaixo, em (46a) "não tem gente que anda de Porsche na Freguesia do Ó, mas tem gente que ande de Porsche nos Jardins' - mas, de qualquer modo, o ponto é: gente que ande de Porsche não parece significar a mesma coisa que gente que anda de Porsche nesses contextos. Dessa maneira, aqui também, seria impreciso propor que estamos diante de um formas variantes. Estamos, antes, de formas alternantes, possiveis num contexto que é evidentemente de subordinação, mas que veiculam conceitos diferentes (no eixo realis - irrealis).

\subsection{ANÁlISE VARIACIONISTA PARA ALÉM DO NÍVEL FONOLÓGICO}

De acordo com a tradição gramatical da língua portuguesa, o subjuntivo e o indicativo possuem lugares cativos na estruturação sintática. Cegalla (2007) explica que o subjuntivo é empregado quando se deseja exprimir um fato possível, incerto, hipotético, irreal ou dependente de outro, e que pode ocorrer em orações subordinadas substantivas, adjetivas e adverbais (cf. CUNHA \& CINTRA, 2005). Entretanto, Said Ali (1964) observou que a terminologia adotada não corresponde efetivamente ao uso desses modos, já que, como bem explica, tanto o subjuntivo quanto o indicativo podem ser empregados em orações subordinadas. O autor acrescenta que não parece razoável afirmar que o indicativo é modo pelo qual se enuncia a certeza ou a realidade de um fato, e que o subjuntivo é o modo, seu pólo contrário, o modo da irrealidade, da dúvida ou da incerteza.

Contudo, como bem afirma Oushiro (2011: 8), "uma distribuição geral de frequências não permite uma análise detalhada da variação e 
da língua em uso". Para ela, esse é apenas um primeiro passo no estudo da variação. Nesse sentido, a definição da regra variável não é satisfatória quando entra em questão a expansão desse construto a niveis de linguagem acima do fonológico (cf. CAMACHO: 2013).

A discussão entre Labov (1978) e Lavandera (1978) a respeito desses níveis é importante para este estudo no sentido de verificar se a forma do subjuntivo ou do indicativo são indícios de duas proposições distintas, em que o falante estaria assumindo duas ideias completamente distintas. Em outras palavras, se quando se tem a forma do subjuntivo, tem-se modo subjuntivo, e quando se tem a forma do indicativo, tem-se modo indicativo.

Labov (2008 [1972]; 1978) explica que duas determinadas variantes são semanticamente equivalentes quando o seu valor de verdade se referem a um mesmo estado de coisas.

No entanto, Lavandera (1978) questiona o modo como se argumenta a favor de uma variável sintática, propondo que se alargue a noção de significado referencial e que se considere, em vez disso, a comparabilidade funcional.

(47) The liquor closet was broken into. 'O armário de bebidas foi arrombado'.

(48) They broke into the liquor closet. 'Arrombaram o armário de bebidas'17.

Labov (1978) responde a Lavandera (1978) afirmando que, em vez de estender o significado, dever-se-ia limitá-lo, sob pena de se perder a precisão da análise no âmbito da variação. Labov, então, reafirma a importância de estabelecer um envelope de variação com a

17 Os exemplos foram extraídos do texto de Lavandera (1978) e as traduções foram propostas por Oushiro (2011). 
devida atenção à equivalência semântica em que se observa não somente a possivel variação entre as estruturas (fonológicas ou sintáticas), mas também os seus contextos de ocorrência.

Da mesma forma como Lavandera fez com os exemplos (47) e (48) acima, faz-se necessário questionar se as formas do indicativo e do subjuntivo podem ser entendidas como formas alternativas de se dizer a mesma coisa; em outras palavras, se são variantes de uma mesma variável.

Considerando-se aquilo que estabelece a tradição gramatical do português brasileiro, o indicativo e o subjuntivo são modos verbais distintos que veiculam uma oposição, cujo valor semântico reside no grau de certeza do falante em relação ao conteúdo de sua proposição.

Nesse sentido, o objetivo central dessa pesquisa é verificar se o emprego do subjuntivo está se tornando mais restrito em português brasileiro - especificamente, em duas variedades: a paulistana e a ludovicence. Desse modo, diante da análise qualitativa introdutória acima, propõem-se conjuntos separados de análises quantitativas das ocorrências extraídas de 36 entrevistas com paulistanos e de 36 entrevistas com ludovicenses:

(i) dados como aqueles de (20) a (31)

(ii) dados como aqueles de (32) a (41)

(iii) dados como aqueles de (42) a (46)

Esses conjuntos de análises se justificam, em primeiro lugar, pela questão da natureza dos dados: conforme se discutiu acima, verifica-se variação em (i), mas não em (ii) e (iii). Assim, ainda que se vá utilizar o pacote estatístico Goldvarb X (cf. SANKOFF; TAGLIAMONTE; 
SMITH, 2005) para todas as análises, seus resultados serão abordados à maneira variacionista tradicional para (i), mas de maneira adaptada para (ii) e (iii). Ou seja, em (i), os grupos de fatores (linguísticos e sociais) serão tomados como variáveis independentes que concorrem para o emprego da morfologia de subjuntivo ou indicativo, considerando-se que o modo subjuntivo define o contexto variável; diferentemente, para (ii) e (iii), a análise de correlações entre grupos de fatores e o emprego de um dos dois modos não deverá ser descrita nos mesmos termos de uma análise variacionista. Na verdade, isso significa que, se de um ponto de vista prático, todos os dados serão analisados (ainda que separadamente) de acordo com uma mesma metodologia (no sentido da mesma ferramenta estatística), por outro lado, de um ponto de vista teórico (talvez epistemológico), os três conjuntos de dados não parecem poder ser tratados indistintamente.

Na mesma linha de raciocinio, embora (ii) e (iii) sejam conjuntos de dados estruturalmente diferentes (e como tais serão analisados separadamente um do outro), são semelhantes no que diz respeito à alternância dos modos (de acordo com a proposta que aqui se apresenta). Assim, além de suas análises em separado (com grupos de fatores específicos para cada conjunto), propõe-se uma análise global de ambos. Finalmente, seguindo essa mesma proposta, seria interessante fazer um quinto conjunto de análises quantitativas com os dados dos três conjuntos, ainda que apenas com os grupos de fatores sociais, com vistas a verificar distribuições gerais de dados. Dessa forma, ao mesmo tempo em que se reconhecem as diferenças entre os conjuntos de dados, pode-se ao menos tentar verificar, numa amostra de dados maior, quão frequente é o indicativo, em contextos em que o subjuntivo é possivel. 
No que segue, serão desenvolvidas as questões apresentadas nesta introdução: no capítulo 2 a seguir, trata-se das subamostras que compõem esse trabalho; o capítulo 3 expõe os grupos de fatores que foram estabelecidos e incluídos nas análises; finalmente, o capítulo 4 traz as análises quantitativas dos dados das 72 entrevistas. 


\section{CAPÍTULO 2 CORPUS E MÉTODOS DA PESQUISA}

Os estudos sociolinguísticos, em especial aqueles de cunho laboviano, têm interesse na mudança linguística, bem como em seus processos de encaixamento, avaliação e implementação (cf. WEINREICH, LABOV, HERZOG, 2006). A partir de fatos de variação, interessa verificar se se trata de um fenômeno estável ou de um caso de mudança em progresso. Quando se trata de contextos em que formas verbais subjuntivas e indicativas se alternam - do modo como discute o capítulo anterior -, além de perguntar (i) a que se correlacionam os empregos de uma ou de outra forma?, uma questão que também se apresenta é: (ii) estaria uma das formas tornando-se preferida em alguns casos? Em outras palavras, considerando-se a discussão anteriormente desenvolvida: estaria o indicativo "tomando o lugar" do subjuntivo em certos contextos?

No sentido de responder a questionamentos desse tipo, deve-se partir da análise de um número razoável de ocorrências dessas formas na fala mais espontânea possível dos membros das comunidades de falantes que se pretendem investigar. Neste trabalho, os dados foram extraídos de entrevistas sociolinguísticas coletadas nas capitais São Paulo (pelo Projeto SP2010 - cf. MENDES; OUSHIRO, 2013) e São Luís.

O Projeto SP-2010 reúne entrevistas realizadas com 60 sujeitos nascidos e criados na cidade de São Paulo. Este corpus está disponível em site próprio na Internet ${ }^{18}$ e foi construido no sentido de contribuir para a realização de estudos sobre a fala paulistana, bem como para a sua comparação com a fala de outras comunidades. Recentemente, vêm sendo desenvolvidos trabalhos sobre as mais diversas variáveis sociolinguísticas: a estruturação de interrogativas de conteúdo (Oushiro, 2011); a estruturação de sentenças negativas (Rocha, 2013); a

18 Cf: www.projetosp2010.fflch.usp.br (último acesso: dezembro/2014). 
combinação de orações causais com aí, daí e então (Vieira, 2012); a concordância nominal na fala de paulistanos e alagoanos que se estabeleceram em São Paulo (Gomes da Silva, 2014); a pronúncia de /r/ em coda (Oushiro; Mendes, 2013); a pronúncia de /e/ nasal, em palavras como setenta (Oushiro, inédito); entre outros.

Das 60 entrevistas do Projeto 2010, selecionaram-se 36 - que pudessem ser comparadas aquelas que foram gravadas e transcritas em São Luís, com ludovicenses nativos, especificamente para esta pesquisa. No intuito de comparar os usos de formas subjuntivas e sua alternância com forma indicativas, as entrevistas ludovicenses seguiram um roteiro ${ }^{19}$ semelhante àquele utilizado pelo Projeto SP-2010. Oportunamente, as 36 entrevistas ludovicenses coletadas para a presente pesquisa deverão ser também disponibilizadas ${ }^{20}$.

O interesse nas capitais São Paulo e São Luís - no sentido de verificar se formas indicativas estariam se tornando mais frequentes naqueles contextos em que o subjuntivo é prescrito ou, pelo menos, possivel - está sobretudo em duas impressões popularmente enunciadas: (i) "São Paulo está abandonando o subjuntivo" e (ii) "o português falado por ludovicenses é mais conservador e lembra a variedade portuguesa”.

Em artigo publicado em uma edição ${ }^{21}$ da Revista Época de janeiro de 2006, o colunista Ricardo Freire traz para o nivel da escrita

$19 \mathrm{O}$ roteiro das entrevistas com ludovicenses pode ser visto no Anexo B; o das entrevistas do Projeto SP2010 pode ser acessado no mesmo site em que está disponibilizada a amostra.

20 A presente construção de uma amostra representativa da fala ludovicense é a primeira de que se tem notícia. Contudo, é importante que se faça referência aos dados coletados pelo Grupo de Estudos e Pesquisa em Lusofonia, que conta com 16 entrevistas realizadas com sujeitos nascidos em São Luís, além de outras cidades do interior do estado, para a elaboração do Atlas Linguístico do Brasil e do Atlas Linguístico do Maranhão (cf. RAMOS, 2009).

${ }^{21}$ Revista Época, edição 400, ano 8, jan. de 2006, p. 96. 
as possiveis percepções sobre as variantes utilizadas pelos falantes paulistanos para expressar o modo subjuntivo na capital. O autor revela que ouvir estruturas do tipo "quer que eu jogo fora?" (em vez de "quer que eu jogue fora"), ou ainda "quer que joga fora?", é a "comprovação" de que se está na capital paulista. Além disso, o autor sugere que utilizar a forma "correta" (ou seja, o subjuntivo) é mais incomum em São Paulo do que realizar a concordância nominal. Não vem ao caso discutir se o repórter está certo ou errado em suas impressões (muito embora esta dissertação ofereça evidências de que o subjuntivo continua bastante produtivo - inclusive na fala de nativos da capital paulista), mas o fato de que tais impressões e avaliações existentes justifica o interesse em desenvolver um trabalho que se baseie numa grande quantidade de dados que permita, de fato, verificar a produção dessas formas, nos contextos em que elas são possíveis e factualmente empregadas ${ }^{22}$.

Se por um lado ocorrem afirmações impressionísticas de que “paulistanos não usam o subjuntivo", por outro há o "mito" de que, em São Luís, encontra-se "a melhor variedade do português falado no Brasil”. Veja-se, por exemplo, o que diz Serra (1965:17), então interventor do Maranhão na chamada era Vargas (1930-1945):

S. Luís é uma terra onde se amam os versos, os recitativos, a oratória, as tertúlias literárias e onde existe verdadeiro culto pela arte de dizer e de escrever. Discute-se gramática com a mesma paixão com que se discute politica. Por uma discussão em tôrno do vernáculo dá-se ali a vida; e até ferrenhas inimizades surgem, muitas vêzes, por causa de uma simples colocação de pronome, ou por uma regrazinha de sintaxe...

O autor explica que essa característica do falar maranhense se dá pelo fato de que muitos de seus 'intelectuais' tiveram sua formação

22 OUSHIRO (inédito) analisa a variação na concordância nominal, além de verificar, numa amostra ainda maior (118 entrevistas) que a não realização da concordância normalmente é associada a um "falar paulistano". Entretanto, suas análises de produção indicam que se trata de uma variável estável na comunidade e que a taxa geral de não realização da concordância é da ordem de 15\% (num total de mais de 17.000 ocorrências de sintagmas nominais plurais). 
consolidada em Portugal. Da perspectiva de quem fala na primeira metade do século XX, o autor acrescenta, citando Afrânio Peixoto, que "influição do saber [...] tem suas raizes na velha Coimbra, onde estudaram gerações e gerações de maranhenses" (SERRA, 1965:18). Para ele, o "bem falar" seria um dos orgulhos do ludovicense.

Também Honório do Couto (1986: 50) e Travaglia (1996) explicam que essa "crença" - de que São Luís é o lugar do Brasil onde melhor se fala o português - é bastante disseminada popularmente. Honório do Couto acrescenta ainda que, "em outros termos, em São Luís se fala 'bom português' porque a linguagem de lá é mais parecida com a de Portugal, a qual foi levada para lá no passado”.

Regressando-se um pouco mais no tempo, pode-se verificar que essa percepção acerca do falar maranhense parece atravessar gerações. Avaliações semelhantes sobre o falar ludovicense e maranhense podem ser encontradas em obras de cunho histórico. Ao escrever, no ano de 1819, a sua obra Porandunba Maranhense, o Frei Francisco de Nossa Senhora dos Prazeres Maranhão ${ }^{23}$ já afirmava que é na capital maranhense que se fala um português "[...] com um certo metal de voz, que o faz muito agradável ao ouvido" (PRAZERES MARANHÃO, 1946: 146).

Essa afirmação de Prazeres Maranhão está bastante associada a uma percepção geral e corrente sobre o português ludovicense, caracterizado por uma suposta "falta de sotaque". Nas entrevistas gravadas para a presente pesquisa, não são raras avaliações nesse sentido:

${ }^{23}$ Aqui citado pela edição de 1945. 
(49) D1: tu me disseste que que as pessoas reconheceram que tu era ludovicense até falar né

S1: é

D1: eles acham que a gente fala...

$\mathrm{S} 1$ : eles acham que a gente fala cantando

S1: eles falam que a gente fala cantando

D1: tu acha isso também?

S1: eu acho que a gente fala muito bem a gente fala explicadinho detalhado

S1: a gente fala muito bem

D1: não cantado né

S1: não cantado

D1: tá certo

(SLM2B-OsvaldoS.)

(50) D1: como que é o modo de falar ludovicense?

S1: rapaz eu acho que o ludovicense é o que fala mais normal

S1: sem sotaque

D1: do Brasil inteiro?

S1: do Brasil

D1: é?

S1: eu acho que a gente não tem um sotaque

S1: a gente não tem uma maneira de falar ou cantando ou correndo

D1: uhum

S1: ou lentamente eu acho que a gente fala normal

D1: tá

S1: não sei uma pesquisa diz que a gente fala/ quem melhor conjuga o verbo somos nós.

(SLM2B-MarcosO.)

Avaliações desse tipo encontram-se também fora de São Luís como ocorre no excerto abaixo, transcrito de uma das entrevistas do Projeto SP2010:

(51) S1: e você tem o nordestino que vem com aquele sotaque tão gostoso... né e o maranhense que fala um português acho que o mais correto do Brasil né talvez por ter sido colonizado pelos portugueses depois teve aqueles episódios das invasões holandesas e francesas e tudo.

(SPM3S-NiltonR.)

É possivel que qualquer falante (que não seja um linguista) acredite-se "sem sotaque" - uma qualidade que pode ser mais facilmente atribuída ao "outro". À presente pesquisa interessa, contudo, não discutir longamente as diferentes avaliações aqui exemplificadas, mas sim justificar a comparação, aqui proposta, entre as falas paulistana e ludovicense, com vistas aos usos do modo subjuntivo e 
sua alternância com formas indicativas. Se as avaliações e impressões aqui relatadas estão corretas, seria de esperar que, num estudo de amostras comparáveis (ambas contêm 36 entrevistas, planejadas e gravadas com base nos mesmos métodos de coleta), formas do subjuntivo seriam mais rarefeitas na fala paulistana (pelo menos em alguns contextos), enquanto que formas do indicativo seriam mais evitadas por ludovicences - sobretudo nos contextos em que se prescreve o emprego do subjuntivo.

A distribuição geral das ocorrências de formas subjuntivas e indicativas - em cada amostra (ludovicense e paulistana), para cada um dos contextos em que as duas formas são possiveis (orações subordinadas adverbiais, substantivas e relativas) - é apresentada no capítulo a seguir. Antes, porém, é preciso descrever a metodologia de coleta das entrevistas e suas características sociais.

\subsection{AS AMOSTRAS DE FALA PAULISTANA E LUDOVICENSE}

A pesquisa sociolinguística, em especial a variacionista, busca entender a sistematicidade do fenômeno variável, seu encaixamento social e linguístico. Em outras palavras, objetiva desvendar padrões de empregos de formas variantes, através da análise quantitativa de suas ocorrências. Tais análises quantitativas consistem de testes estatísticos acerca de correlações entre variáveis independentes e a variável dependente em foco. As variáveis independentes são os grupos de fatores linguísticos (cuja natureza pode ser fonética, fonológica, morfológica, sintática e discursiva - de acordo com as hipóteses que se aventam) e sociais (sexo/gênero, faixa etária, escolaridade, classe social, etc).

As hipóteses linguísticas e sociais são desenvolvidas mais propriamente no capítulo 3, mas aqui convém descrever como se constituíram as amostras paulistana e ludovicense - que foram, ambas, 
estratificadas de acordo com o sexo/gênero do falante (masculino e feminino), dois niveis de escolaridade (até a educação básica ou superior) e três faixas etárias (18 a 35 anos; 36 a 59 anos; e 60 anos ou mais). As seções a seguir tratam, respectivamente, da construção da amostra SP2010 (da qual foram selecionadas 36 entrevistas para a presente pesquisa) e da amostra ludovicense, que seguiu as orientações do Projeto SP2010.

\subsubsection{A amostra paulistana}

Os primeiros estudos sobre a lingua falada no Brasil iniciaramse por volta da década de 70, com o projeto NURC - Norma Linguística Urbana Culta - (cf. CASTILHO \& PRETI, 1986, 1987; PRETI \& URBANO, 1988, 1990). Tal projeto coletou dados em cinco capitais brasileiras entre elas, São Paulo. Mais recentemente, o Projeto Iboruna (Gonçalves, 2008) construiu uma amostra com falantes do interior do estado de São Paulo, na região de São José do Rio Preto ${ }^{24}$. No sentido de contribuir para o desenvolvimento da pesquisa sociolinguística na cidade de São Paulo, o Grupo de Estudos Sociolinguísticos ${ }^{25}$ vem gravando, desde 2006, entrevistas com paulistanos - habitantes da cidade de São Paulo que nela nasceram e foram criados. O Projeto SP2010, especificamente, disponibilizou 60 entrevistas das entrevistas gravadas entre 2011 e 2013.

As entrevistas do Projeto SP2010 têm caráter semi-espontâneo (cf. MENDES; OUSHIRO, 2012) - isto é, embora tenham atentado para o Paradoxo do Observador (LABOV, 2006 [1966]), amostra-se uma fala com algum nível de automonitoramento, por parte do sujeito que concede a entrevista. Para que fossem evitados ao máximo os efeitos causados pelo automonitoramento da fala do informante, planejou-se um roteiro, que deveria ser previamente estudado pelo documentador,

${ }^{24} \mathrm{Cf}:<$ http: / $/$ www.iboruna.ibilce.unesp.br/interna.php?Link=corpo.php\&corpo $=36>$. Último acesso: dezembro de 2014.

25 O GESOL-USP, coordenado pelo Prof. Dr. Ronald Beline Mendes, é formado por alunos de Iniciação Científica, Mestrado e Doutorado. 
no sentido de conduzir a entrevista da maneira mais informal possivel, como se fosse uma entrevista que não estivesse sendo gravada com o propósito de coletar dados para análise linguística ulterior.

O método de seleção de informantes foi semi-aleatório, de acordo com o modelo “amigo do amigo" (cf. MILROY, 2004), em que o contato com um determinado informante é intermediado por uma terceira pessoa; dessa maneira, possibilita-se um primeiro contato menos artificial com o sujeito a ser entrevistado e garante-se, ao mesmo tempo, alguma aleatoriedade e abrangência, já que tal método leva a grupos sociais bastante diversificados, numa cidade demograficamente tão complexa como São Paulo. Após um primeiro contato com o informante, agenda-se uma "conversa" com o sujeito, esclarecendo-se que ele será $\operatorname{gravado}^{26}$.

O roteiro para as entrevistas é composto de duas partes (cf. Anexo A). Na primeira, conversa-se sobre o bairro em que o falante mora (ou morou na maior parte de sua vida), sua infância, sua família, educação (escolas em que estudou), sua ocupação, suas redes sociais e atividades de lazer. A inclusão desses tópicos de cunho mais pessoal contribui para o desenvolvimento de uma conversa mais espontânea (do que potencialmente poderia ser, por exemplo, a discussão de um assunto de natureza política em voga à época da gravação da entrevista). A segunda parte do roteiro envolve questões sobre percepções do falante sobre a cidade, bem como avaliações sobre determinadas variantes linguísticas (tais como pronúncia do /r/ pósvocálico e concordância nominal). Ao final, pede-se ao informante que leia uma lista de palavras, um texto jornalístico e um depoimento - este último, caracterizado por marcas de oralidade. A inclusão desses textos

\footnotetext{
26 Ao final da entrevista, pede-se ao informante que assine um termo de livre consentimento, em que se autoriza a utilização da entrevista para fins de pesquisa sociolinguística. Dados e informações de natureza pessoal são apagados das gravações e omitidos das transcrições. Para maiores detalhes acerca disso, ver: www.projetosp2010.fflch.usp.br.
} 
e da lista de palavras para leitura segue a orientação laboviana (Labov, 2006 [1966]), no sentido de obter variação de "estilo" (mais casual, na conversa, e mais cuidadoso/monitorado, nas leituras).

A estratificação da amostra em Sexo/Gênero, Faixa Etária gera 12 perfis sociolinguísticos, conforme resume o quadro abaixo:

Quadro 127: Perfis sociolinguísticos da amostra

\begin{tabular}{|c|c|c|c|}
\hline SEXO/GÊNERO & FAIXA ETÁRIA & ESCOLARIDADE & $\begin{array}{c}\text { PERFIL } \\
\text { SOCIOLINGUÍSTICO }\end{array}$ \\
\hline \multirow{6}{*}{$\begin{array}{c}\mathrm{M} \\
\text { masculino }\end{array}$} & \multirow{2}{*}{$\begin{array}{c}1 \\
\text { (18-35 anos) }\end{array}$} & \multirow{3}{*}{$\begin{array}{c}\mathrm{M} \\
\text { (até o ensino médio) }\end{array}$} & 1. M1M \\
\hline & & & 2. M1S \\
\hline & \multirow{2}{*}{$\begin{array}{c}2 \\
\text { (36-59 anos) } \\
\end{array}$} & & 3. M2M \\
\hline & & \multirow{3}{*}{$\begin{array}{c}\mathrm{S} \\
\text { (até o ensino superior) }\end{array}$} & 4. M2S \\
\hline & \multirow{2}{*}{$\begin{array}{c}3 \\
(60 \text { anos ou }+)\end{array}$} & & 5. M3M \\
\hline & & & 6. M4S \\
\hline \multirow{6}{*}{ FEMININO } & \multirow{2}{*}{$\begin{array}{c}1 \\
(18-35 \text { anos) }\end{array}$} & \multirow{3}{*}{$\begin{array}{c}\mathrm{M} \\
\text { (até o ensino médio) }\end{array}$} & 7. F1M \\
\hline & & & 8. F1S \\
\hline & \multirow{2}{*}{$\begin{array}{c}2 \\
\text { (36-59 anos) }\end{array}$} & & 9. F2M \\
\hline & & \multirow{3}{*}{$\begin{array}{c}\mathrm{S} \\
\text { (até o ensino superior) }\end{array}$} & 10. F2S \\
\hline & \multirow{2}{*}{$\begin{array}{c}3 \\
(60 \text { anos ou }+)\end{array}$} & & 11. F3M \\
\hline & & & 12. F3S \\
\hline
\end{tabular}

Para o Projeto SP2010, foram gravados cinco informantes para cada um dos perfis acima (um de cada zona da cidade - norte, sul, leste, oeste e centro), para um total de 60 entrevistas. Dentre elas, selecionaram-se 36 para o estudo comparativo com a amostra ludovicense - que contém este número de informantes, gravados especificamente para a presente pesquisa, conforme se descreve a seguir.

\subsubsection{A amostra ludovicense}

A variedade ludovicense ainda não foi amplamente descrita, diferentemente de outras variedades do português brasileiro. Recentemente, com as publicações do Projeto Atlas Linguístico do Maranhão (ALiMA-UFMA), o português falado naquele estado vem sendo descrito de maneira mais sistemática. As publicações pouco numerosas

\footnotetext{
${ }^{27}$ Adaptado de Mendes e Oushiro (2012).
} 
sobre o português maranhense se iniciam com Mota (1976 [1928]), no apêndice Linguagem Popular, com registros léxico-semânticos dessa região, a partir da literatura oral dos cantadores sertanejos no Estado.

Com sua obra $\mathrm{Na}$ terra das palmeiras, Abreu (1931) faz um levantamento da história e da geografia do Estado. Nela, o autor registra a lingua de comunidades indígenas, como os Guajajara e os Canela, além de fazer um levantamento das expressões populares maranhenses. Em A linguagem popular do Maranhão, Vieira Filho (1958) compila mais de mil vocábulos representativos do português falado no Maranhão um dos trabalhos pioneiros que podem ser considerados dos mais consistentes e sistemáticos sobre a linguagem popular maranhense (cf. RAMOS, 1999).

O segundo momento dos trabalhos descritivos sobre o português falado no Maranhão é representado pelos estudos de Azevedo (1973, 1976) e Azevedo et al. (1980). Sem perder de vista os aspectos semântico-lexicais, o autor pesquisou aspectos fonético-fonológicos, morfossintáticos e prosódicos próprios dos falares maranhenses ${ }^{28}$.

Apesar desses importantes trabalhos, é somente com o ALiMAUFMA que vai haver um aprofundamento na descrição do falar maranhense. Muitos estudos têm sido desenvolvidos no âmbito do projeto, tais como Ramos (1996), que estudou o preenchimento da posição de sujeito pelos pronomes pessoais, Alves (2010), que fez uma análise variacionista dos pronomes tu e você, e Santos (2011) que estudou a variação entre o futuro do pretérito e o pretérito imperfeito do indicativo em construções hipotéticas. Contudo, é na área da lexicologia que as pesquisas são mais numerosas (cf. ROCHA, 2008; CURVELO, 2009; SANTOS, 2009).

28 Tais estudos sobre os falares maranhenses são considerados pioneiros, por enfocar diversos níveis de análise linguística - fonético-fonológicos, morfossintáticos e prosódicos - diferentemente do que vinha sendo feito em estudos anteriores que se dedicaram basicamente a fatos semântico-lexicais. 
Para o desenvolvimento do ALiMA, foram coletadas algumas entrevistas sociolinguísticas (com 8 informantes ludovicenses, apenas) ${ }^{29}$. Embora suficiente para os interesses daquele Projeto, tais entrevistas não poderiam ser utilizadas para esta pesquisa, já que foram gravadas com base em um roteiro bastante diferente daquela das entrevistas com paulistanos, da amostra SP2010. Para os propósitos comparativos do presente estudo, era necessário, então, coletar novas entrevistas com ludovicenses.

Conforme mencionou-se anteriormente, o roteiro para a gravação de entrevistas com ludovicenses, na cidade de São Luís, baseou-se amplamente naquele utilizado pelo Projeto SP2010. Fizeramse necessárias, contudo, algumas adaptações. Se para a amostra da fala paulistana o roteiro foi proposto de modo a proporcionar conversas que revelassem a identificação dos informantes com a capital paulista, para que se obtivesse o mesmo tipo de material da fala ludovicense, alguns pontos do roteiro precisaram ser alterados, sobretudo no que diz respeito à relação do informante com a cidade e à leitura de uma notícia de jornal (para a qual selecionou-se uma notícia local). Tal roteiro pode ser consultado no Anexo B.

Levando-se em conta os necessários limites de tempo para a integralização de uma pesquisa de mestrado, gravaram-se 3 informantes para cada um dos perfis indicados no Quadro 1 (apresentado na subseção anterior). Evidentemente, teria sido melhor se

29 O ALiMA realizou entrevistas ainda em outras 8 cidades do interior maranhense (Araioses, Carolina, Carutapera, Caxias, Codó, Maracaçumé, Pinheiro, Santa Luzia e Raposa). Os informantes do ALiMA são em número de quatro em cada localidade investigada, exceto em São Luís, onde foram entrevistadas oito pessoas. Essa amostra foi estratificada em duas faixas etárias - faixa I, de 18 a 30 anos, e faixa II, de 50 a 65 anos; quanto à escolaridade, foram considerados sujeitos alfabetizados e que cursaram, no máximo, até a 4a série do Ensino Fundamental. Apenas na capital do Estado, onde há maior densidade populacional e grande diversidade de estratos sociais, foram incluídos universitários. Os informantes são naturais da localidade linguística pesquisada, não se tendo dela afastado por mais de um terço de suas vidas. 
mais informantes pudessem ter sido gravados; de todo modo, Labov (2006[1966]) recomenda que se gravem no mínimo três informantes por perfil - já que, com menos informantes, torna-se mais dificil determinar se os padrões verificados através das análises quantitativas se devem aos usos na comunidade amostrada, ou se trata-se de usos idiossincráticos. Em outras palavras, quanto mais informantes por perfil, melhor (qualquer que seja a estratificação de uma amostra; qualquer que seja a variável em foco); mas o exame estatisticamente confiável de fatos de variação linguística requer pelo menos três informantes por perfil.

Abaixo, o Quadro 2 indica os pseudônimos dos 72 informantes, cujas entrevistas foram utilizadas na presente pesquisa.

Quadro 2: Informantes das subamostras paulistana e ludovicense

\begin{tabular}{|c|c|c|c|c|c|c|c|c|}
\hline \multirow[b]{3}{*}{$\begin{array}{l}\text { Faixa } \\
\text { Etária }\end{array}$} & \multicolumn{4}{|c|}{ Paulistanos } & \multicolumn{4}{|c|}{ Ludovicenses } \\
\hline & \multicolumn{2}{|c|}{ Homens } & \multicolumn{2}{|c|}{ Mulheres } & \multicolumn{2}{|c|}{ Homens } & \multicolumn{2}{|c|}{ Mulheres } \\
\hline & Médio & Superior & Médio & Superior & Médio & Superior & Médio & Superior \\
\hline $\begin{array}{l}18-35 \\
\text { anos }\end{array}$ & $\begin{array}{l}\text { NicolauS. } \\
\text { DalsonO. } \\
\text { EvandroO. }\end{array}$ & $\begin{array}{c}\text { GuilhermeV. } \\
\text { JaimeN. } \\
\text { RodrigoR. }\end{array}$ & $\begin{array}{c}\text { MilenaF. } \\
\text { JanainaB. } \\
\text { LaraN. }\end{array}$ & $\begin{array}{c}\text { SilviaB. } \\
\text { Valéria } \\
\text { BiancaB. }\end{array}$ & $\begin{array}{c}\text { MarcosS. } \\
\text { MarceloO. } \\
\text { LuisJ. }\end{array}$ & $\begin{array}{l}\text { EduardoE. } \\
\text { CarlosH. } \\
\text { ArthurL. }\end{array}$ & $\begin{array}{c}\text { MariaF. } \\
\text { ValériaD. } \\
\text { MarcelaF. }\end{array}$ & $\begin{array}{c}\text { TatianaJ. } \\
\text { SofiaS. } \\
\text { PalomaR. }\end{array}$ \\
\hline $\begin{array}{c}36-59 \\
\text { anos }\end{array}$ & $\begin{array}{l}\text { NelsonF. } \\
\text { SandroS. } \\
\text { MaurícioB. }\end{array}$ & $\begin{array}{l}\text { JoséN. } \\
\text { PedroS. } \\
\text { RafaelV. }\end{array}$ & $\begin{array}{c}\text { PamelaR. } \\
\text { MarietaS. } \\
\text { MeireC. }\end{array}$ & $\begin{array}{l}\text { ElaineS. } \\
\text { Morgana } \\
\text { Luciana }\end{array}$ & $\begin{array}{l}\text { JoséM. } \\
\text { OsvaldoS. } \\
\text { JoaquimM. }\end{array}$ & $\begin{array}{l}\text { PedroH. } \\
\text { ClaudioM. } \\
\text { InacioS. }\end{array}$ & $\begin{array}{c}\text { AdalbertaC. } \\
\text { MarianeR. } \\
\text { WilmaB. }\end{array}$ & $\begin{array}{c}\text { Flaviane } \\
\text { Manuela } \\
\text { AndreiaL. }\end{array}$ \\
\hline $\begin{array}{c}60 \text { anos } \\
\text { ou }+\end{array}$ & $\begin{array}{c}\text { RodolfoR. } \\
\text { RomuloS. } \\
\text { HugoF. }\end{array}$ & $\begin{array}{l}\text { NiltonR. } \\
\text { LucioP. } \\
\text { NeimarV. }\end{array}$ & $\begin{array}{c}\text { DarcyM. } \\
\text { CarmenF. } \\
\text { Marcia }\end{array}$ & $\begin{array}{c}\text { Vania } \\
\text { Madalena } \\
\text { NairC. }\end{array}$ & $\begin{array}{c}\text { NeilsonS. } \\
\text { JorgeL. } \\
\text { EmersonM. }\end{array}$ & $\begin{array}{c}\text { AndersonR. } \\
\text { FelipeC. } \\
\text { PabloS. }\end{array}$ & $\begin{array}{l}\text { DayseR. } \\
\text { AnaC. } \\
\text { SuzanaC. }\end{array}$ & $\begin{array}{c}\text { Elisangela } \\
\text { R. } \\
\text { ElaineM. } \\
\text { ZafiraS. }\end{array}$ \\
\hline
\end{tabular}

Dessa forma, além de seu interesse específico - permitir o acesso a ocorrências de contextos em que formas subjuntivas e indicativas são possiveis (numa comparação da fala de nativos de duas capitais brasileiras tão distintas), este trabalho também contribui, ao coletar uma amostra da fala ludovicense, para a documentação do português falado num país de extensões continentais. Considerando-se que se pretende, oportunamente, disponibilizar tal amostra, espera-se que ela 
possa ser expandida e futuramente utilizada para o desenvolvimento de outras pesquisas linguísticas. 


\section{CAPÍTULO 3 HIPÓTESES DE CORRELAÇÃO}

O pressuposto básico dos estudos sociolinguísticos é o de que as linguas são inerentemente heterogêneas e que tal heterogeneidade é regulada (e não caótica). Conforme vimos anteriormente, esta pesquisa enfoca formas subjuntivas e indicativas que podem ocorrer em orações subordinadas adverbiais, substantivas e relativas. No capítulo 1, propõe-se que as formas do subjuntivo e do indicativo funcionam como variantes nas orações adverbiais - já que, nelas, pode-se entender que as formas verbais constituem "modos diferentes de dizer a mesma coisa" (a definição laboviana de variantes de uma variável). Entretanto, ainda que nas outras duas estruturas de subordinação seja mais preciso falar em termos de alternância de formas, nos três contextos deve haver fatores que se correlacionam à ocorrência de formas do subjuntivo ou do indicativo.

De acordo com Labov (2008 [1972]: 214), “[...]as pressões internas, estruturais, $e$ as pressões sociolinguisticas agem em alternância sistemática no mecanismo da mudança linguistica". Desse modo, a partir da análise qualitativa dos dados, aventam-se hipóteses sobre variáveis - tanto de natureza linguística quanto social - que podem se correlacionar com a ocorrência das formas variantes/alternantes. Essas hipóteses se traduzem nos chamados grupos de fatores.

Alguns desses grupos de fatores que aqui se estabelecem, com base não só na análise qualitativa dos dados, mas também a partir de trabalhos anteriormente desenvolvidos (PIMPÃO, 1999; 2012; MEIRA, 2006; FAGUNDES, 2007, WHERRITT, 1977) são o verbo da oração principal (especificamente para o caso das orações substantivas, encaixadas na posição de complemento verbal), o tempo verbal (tanto para na oração principal quanto da subordinada), o tipo de 
subordinador (para o caso das orações adverbiais). Estes e outros grupos de fatores são descritos e justificados nas subseções a seguir.

A análise quantitativa consiste, basicamente, em testes de natureza estatística (regressão logística), através dos quais se verifica se as hipóteses se confirmam ou não - em outras palavras, se os grupos de fatores estabelecidos são ou não estatisticamente significativos para a ocorrências das formas variantes/alternantes. No presente trabalhos, esses testes foram feitos com o pacote GoldVarb X (SANKOFF; TAGLIAMONTE; SMITH, 2005) que indica quais dos grupos de fatores são significativos fornece pesos relativos (indices que variam de zero a um, mas nunca se igualam a esses valores), que indicam tendências de ocorrências de uma ou de outra forma (aquele que se estabelece como valor de aplicação da análise estatística) diante dos fatores de cada grupo.

As tabelas abaixo trazem as distribuições gerais das formas indicativas e subjuntivas para as duas amostras, em cada uma das estruturas de subordinação. Cada uma dessas estruturas correspondem a conjuntos de dados que foram analisados separadamente. Ao final, todos os dados foram analisados em conjunto, a fim de verificar se o grupo "cidade" (São Paulo ou São Luís) é selecionado como estatisticamente relevante - ou seja, se há tendências significativamente diferentes de emprego do subjuntivo e do indicativo. 
Tabela 1: Distribuição geral dos dados - São Paulo

\begin{tabular}{cccccc}
\hline $\begin{array}{c}\text { Orações } \\
\text { Subordinadas }\end{array}$ & $\begin{array}{c}\mathbf{N} \\
\text { Indicativo }\end{array}$ & $\mathbf{\%}$ & $\begin{array}{c}\mathbf{N} / \% \\
\text { Subjuntivo }\end{array}$ & $\%$ & Total \\
\hline Adverbiais & 172 & 29 & 414 & 71 & 586 \\
Substantivas & 96 & 53 & 85 & 47 & 181 \\
Relativas & 127 & 52 & 115 & 48 & 242 \\
Total & & 39,1 & & 69,9 & 1009 \\
\hline
\end{tabular}

Tabela 2: Distribuição geral dos dados - São Luís

\begin{tabular}{cccccc}
\hline $\begin{array}{c}\text { Orações } \\
\text { Subordinadas }\end{array}$ & $\begin{array}{c}\mathbf{N} \\
\text { Indicativo }\end{array}$ & $\%$ & $\begin{array}{c}\mathbf{N} / \% \\
\text { Subjuntivo }\end{array}$ & $\%$ & Total \\
\hline Adverbiais & 84 & 22,3 & 293 & 77,7 & 377 \\
Substantivas & 63 & 33,5 & 125 & 66,5 & 188 \\
Relativas & 99 & 39 & 155 & 61 & 254 \\
Total & & 39,1 & & 69,9 & 819 \\
\hline
\end{tabular}

Esses dados foram codificados e analisados de acordo com os grupos de fatores resumidos nos quadros 3 e 4 a seguir.

Quadro 3: Grupos de fatores sociais

\begin{tabular}{ll}
\hline Grupo & Fatores \\
\hline Cidade de Origem & São Paulo \\
& São Luís \\
\hline \multirow{2}{*}{ Sexo/Gênero } & Masculino \\
& Feminino \\
\hline \multirow{2}{*}{ Faixa Etária } & $18-35$ anos \\
& $36-59$ anos \\
\hline \multirow{2}{*}{ Escolaridade } & 60 anos ou mais \\
& Até o Ensino Médio \\
\hline
\end{tabular}

Esses grupos de fatores sociais, de fato, são aqueles que estratificam as amostras - conforme descreve o capitulo 2. Entretanto, eles não deixam de ser hipóteses - que são parte da grande maioria dos trabalhos de pesquisa sociolinguística. Na subseção a seguir, tais hipóteses são brevemente revistas. 
No que diz respeito aos grupos de fatores linguísticos, nem todos foram incluídos nas análise dos três diferentes conjuntos de dados - pois estruturas diferentes requerem análises específicas. De todo modo, o quadro 4 elenca todos eles. Ao final deste capítulo, especificam-se quais grupos foram incluídos nas análises de cada conjunto de dados. 
Quadro 4: Grupos de fatores linguísticos

\begin{tabular}{|c|c|}
\hline Grupo & Fatores \\
\hline \multirow{3}{*}{ Conjunto de Dados } & Orações Adverbiais \\
\hline & Orações Substantivas \\
\hline & Orações relativas \\
\hline \multirow{3}{*}{ Verbo da Oração Principal } & Verbos Cognitivos - achar, pensar, acreditar etc \\
\hline & Verbos Volitivos - querer, desejar, pedir etc \\
\hline & Verbos Factivos - exigir, deduzir etc \\
\hline \multirow{3}{*}{$\begin{array}{l}\text { Tempo Verbal da Oração } \\
\text { Principal }\end{array}$} & Presente \\
\hline & Pretérito \\
\hline & Futuro \\
\hline \multirow{3}{*}{$\begin{array}{l}\text { Tempo Verbal da Oração } \\
\text { Subordinada }\end{array}$} & Presente \\
\hline & Pretérito \\
\hline & Futuro \\
\hline \multirow{4}{*}{$\begin{array}{l}\text { Grau de Assertividade da } \\
\text { Oração }\end{array}$} & Afirmação na Matriz/ Afirmação na Encaixada \\
\hline & Afirmação na Matriz / Negação na Encaixada \\
\hline & Negação na Matriz / Afirmação na Encaixada \\
\hline & Negação na Matriz / Negação na Subordinada \\
\hline \multirow{4}{*}{$\begin{array}{l}\text { Distância entre o pronome relativo } \\
\text { e a forma verbal em foco }\end{array}$} & Adjacentes \\
\hline & Há um elemento entre os itens \\
\hline & Há Existência de dois itens \\
\hline & Existência de três ou mais itens \\
\hline \multirow{10}{*}{ Tipo de Subordinador } & $\mathrm{Se}$ \\
\hline & Embora \\
\hline & Talvez \\
\hline & Tomara \\
\hline & Quando \\
\hline & Enquanto \\
\hline & Mesmo que / Por mais que/ Desde que / Pelo que / \\
\hline & Para que / Ainda que / Até que / À medida que \\
\hline & Não que / Não é que / Não é porque / A não ser que \\
\hline & / Nem que / A menos que \\
\hline \multirow{2}{*}{ Ordem da Oração } & Prótase + Apódose \\
\hline & Apódose + Prótase \\
\hline
\end{tabular}




\title{
3.1. HIPÓTESES SOCIAIS
}

É indiscutível, nos estudos sociolinguísticos, a importância da inclusão das variáveis de cunho social. Bentivoglio (1989: 19) explica que, como no caso de qualquer hipótese que se aventa, é possivel que não se verifique correlação entre variáveis sociais e uma variável dependente, sobretudo quando se trata de um caso de variação morfossintática. Entretanto, recomenda que isso só seja afirmado após a análise.

\begin{abstract}
"Que valor têm as variáveis extralingüísticas nos estudos sobre sintaxe? É possivel que nenhuma. Mas para afirmar isto, é preciso antes prová-lo. E como prová-lo, se não se dispõe dos materiais necessários? Quer dizer, admito que em muitas análises sintáticas não haverá diferenças devidas a fatores extralinguisticos, e que só os fatores lingüísticos serão importantes. Não obstante, renunciar de antemão à possibilidade de comprovar não me parece posição cientificamente desejável. [...] Caso os fatores extralingüisticos se mostrem irrelevantes, faça-se constar isso, e passe-se à discussão dos fatores lingüisticos". (BENTIVOGLIO, 1987:19)
\end{abstract}

A seguir, justificam-se os grupos de fatores linguísticos estabelecidos para esta pesquisa.

\subsubsection{Cidade de Origem}

A hipótese por trás desse grupo de fatores foi delineada no capítulo anterior. Em princípio, considerando-se que São Paulo e São Luís parecem configurar-se como duas comunidades de fala distintas, já é de interesse verificar se as formas em foco tendem a ser empregadas diferentemente pelos seus respectivos conjuntos de falantes. Além disso, são comuns avaliações sociais no sentido de que São Paulo tende a empregar formas indicativas em contextos nos quais se esperam (ou se prescrevem) formas subjuntivas, ao passo que se considera São Luís um local em que a fala é relativamente mais conservadora. Assim, este grupo de fatores visa à verificação dessas avaliações em dados de produção. 
Santos (2012) incluiu a variável "cidade de origem dos informantes" (Rio de Janeiro ou São José do Rio Preto). Seu estudo revelou não haver diferenças entre cariocas e paulistas quanto ao emprego do subjuntivo, de acordo com as taxas aqui transcritas na tabela abaixo. Em ambas as amostras, o subjuntivo é a forma mais frequentemente empregada.

Tabela 3: Corpora Utilizados por Santos (2012)30

\begin{tabular}{ccc}
\hline Corpus & Apl./Total & $\%$ \\
\hline Iboruna/ São José Do Rio Preto & $87 / 120$ & 72 \\
\hline Discurso \& Gramática/ Rio de Janeiro & $70 / 97$ & 72 \\
\hline Total & $157 / 217$ & 72 \\
\hline
\end{tabular}

Fagundes (2007) também verificou a questão dialetal em seu estudo sobre o subjuntivo, ao analisar dados do Projeto Varsul, extraídos de subamostras de quatro localidades - Curitiba, Irati, Londrina e Pato Branco. Seus resultados indicam que é na capital paranaense que o modo indicativo ocorre mais frequentemente nos contextos que, em principio, seriam típicos de subjuntivo.

Estas pesquisas interessam aqui, na medida em que se entende que há diferenças sócio-culturais bastante marcantes entre São Paulo e São Luís, embora sejam duas áreas urbanas. Nesse sentido, busca-se verificar se há diferenças consideráveis na expressão do subjuntivo entre essas duas capitais.

30 Tabela adaptada de Santos (2012). 


\subsubsection{Sexo/Gênero}

A literatura sociolinguística tem mostrado a relevância dessa variável em fenômenos de variação estável e de mudança linguística. Labov (1991) explica que, em situação de variação estável, as mulheres têm demonstrado preferência pelo uso das formas de prestígio e que, em casos de mudança linguística, as mulheres seriam inovadoras e responsáveis pela propagação da variante não-padrão.

Pimpão (2012) verificou que na cidade de Florianópolis são os homens os que mais se correlacionam à forma do presente do subjuntivo, objeto daquele estudo. Entretanto, Fagundes (2007) e Carvalho (2207) não encontraram correlações entre esse grupo de fatores e a expressão do subjuntivo.

De qualquer modo, a variável sexo/gênero possibilita comparar estudos em diversas comunidades, já que tem sido levada em consideração na construção de diversos corpora linguísticos.

\subsubsection{Faixa Etária}

Graças ao construto "tempo aparente" (LABOV, 2001), a faixa etária do falante pode revelar (quando se trabalha com amostras estratificadas em pelo menos três faixas) se a variação ou alternância de formas é um fenômeno estável na comunidade ou se há indício de um processo de mudança.

Baseado na hipótese clássica da aquisição da linguagem (que se encerraria) por volta dos quinze anos, o construto do tempo aparente postula que "o estado atual da língua de um falante adulto reflete o estado da lingua adquirida quando o falante tinha aproximadamente quinze anos de idade" (cf. NARO, 1992: 82). Dessa forma, através de 
diferentes faixas etárias numa amostra de dados, é como se dispusesse de diferentes recortes no tempo - daí o termo "aparente".

Rocha (1997), atestou, em estudo comparativo entre o Rio de Janeiro e Brasília, que parece haver uma variação estável nas duas capitais, tendo em vista que, apesar de os mais jovens utilizarem mais o indicativo, não há uma diferença substancial com relação aos indivíduos mais velhos, que se correlacionam mais ao subjuntivo. Do mesmo modo, Carvalho (2007) verificou que há uma tendência de seleção do subjuntivo entre os sujeitos mais velhos no Ceará. Entretanto, diferentemente daquele estudo, este mostra um processo de mudança se iniciando nesse estado (Range: 26)

Assim, o interesse dessa variável está em verificar se, entre os mais jovens, é maior a tendência de emprego de formas do indicativo, em lugar de formas do subjuntivo, quando ambas são possiveis.

\subsubsection{Escolaridade}

Ainda que não se possa dizer que o subjuntivo tenha, na escola, o mesmo estatuto que concordância verbal, parece razoável considerar que, se há uma tendência geral de substituir formas do subjuntivo por formas do indicativo, tal tendência seria relativamente menor entre falantes com maior nível de escolaridade. Esse foi o padrão encontrado, por exemplo, por Pimpão (1999), que analisou a expressão do presente do subjuntivo, a partir de dados de fala de sujeitos nascidos em Florianópolis, e organizados em três níveis de escolaridade (primário, ginasial e colegial).

Wherritt (1977) analisou a variação indicativo e subjuntivo a partir da aplicação de teste que consistia em completar orações substantivas, adverbiais e adjetivas, entre sujeitos nascidos em algumas cidades da grande São Paulo, incluindo a capital. Mesmo não 
tendo feito análise estatística desses dados, a autora verificou que os sujeitos com menos escolaridade eram os que mais alternavam entre um e outro modos, além de utilizar mais relativamente ao subjuntivo a forma do indicativo.

Na mesma direção desses e de outros estudos variacionistas que analisam esse mesmo grupo de fatores, este estudo tem interesse em verificar se as pressões normativas favorecem a forma considerada mais padrão na língua.

\subsection{HIPÓTESES LINGUÍSTICAS}

Esta seção trata dos grupos de fatores linguísticos, alguns dos quais serão incluídos nas análises de cada um dos três conjuntos de dados, enquanto outros dizem respeito a conjuntos específicos. Ao final desta subseção, os grupos de fatores incluídos em cada análise são elencados em quadros.

\subsubsection{Conjunto de Dados}

Esse grupo só pode ser incluído na análise global, em que todas as ocorrências (em subordinadas adverbiais, substantivas e restritivas) são analisadas em conjunto - com o objetivo de verificar se as formas do indicativo tendem a ser mais empregadas em algum desses contextos.

Conforme discutiu-se no capitulo 1 , as formas do indicativo e do subjuntivo funcionam mais propriamente como variantes de uma variável nas orações subordinadas adverbiais. Nelas, o modo subjuntivo parece composicional (tal como a categoria do aspecto verbal), de modo que ele parece expresso a despeito da forma verbal. De acordo com essa argumentação, em princípio seria de esperar que formas do indicativo 
poderiam estar ocorrendo mais nestes contextos, relativamente às formas subjuntivas.

(52) S1: [se você quisesse namorar] [tinha que ir no pai pra pedir]

(SPM1B-NicolauS).

(53) S1: antigamente era assim [se você queria entrar e sentar] [os mais novos davam o lugar] (SPM1B-NicolauS).

(54) D1:posso? eu vou te dar uma lista de palavras tu pode ler pra mim? S1: eu não enx/... porque eu não leio assim eu só leio só se eu tiver meu óculos... mas [vamos] [antes que o sol vá embora] (SLF3B-GrazielaD.)

(55) S1: quando eu estudava no SENAC que a gente precisava sair mais tarde por causa de algum trabalho que a gente precisava fazer eu sempre dizia pras meninas olha [vamos logo] [antes que eu vou embora]...

(SLF2B-MarianeR.)

(56) S1: minha mãe cuidava da gente então nós estudávamos com ela até nós estudamos com ela até a quarta série ela tomando a lição pessoalmente... até a quarta série... às vezes [talvez eu não lembro direito] eu tenho certeza de que até a quarta série ela tomava a lição acompanhando bem de pró/ bem bem de perto... [talvez na quinta sexta série ela tenha deixado]. (SLM1S-EduardoE.)

Além das subordinadas adverbiais, as formas do indicativo e do subjuntivo se alternam em subordinadas encaixadas na posição de um complemento verbal (exemplos 57 e 58), bem como em orações relativas, que se adjungem a um nome (exemplos 59 e 60). Embora estes sejam contextos de alternância, mais propriamente - conforme discutiu-se no capítulo 1 -, convém verificar, numa análise global, se uma das duas formas tende a ser mais usada nesses contextos de subordinação.

(57) S1: ah [todo mundo todo pai sempre quer] [que o seu filho tire nota boa no colégio né] (SLM3S-FelipeC.)

(58) S1: [eu sempre acredito] [que Deus está com as pessoas de bem]

(SLF3B-AnaC.)

(59) S1: nós não tem assim um líder comunitário alguém [que reinvidica alguma coisa pro bairro] [que $\underline{\text { faz }}$ alguma coisa por nós] (SPM2BNelsonF.)

(60) S1: eu lembro que meu pai sempre comprava os livro [que os professores indicassem] (SPF2B-PamelaR) 


\subsubsection{Verbo da Oração Principal}

A pergunta por trás deste grupo de fatores é: haveria algum verbo na oração principal que mais frequentemente se correlaciona ao emprego do subjuntivo na subordinada? Evidentemente, é uma pergunta que se aplica apenas ao conjunto de dados de orações substantivas encaixadas na posição de complemento verbal.

Carvalho (2007) e Oliveira (2006) verificaram que formas subjuntivas são favorecidas sobretudo por verbos como querer, desejar, acreditar - em dados de fala da região do Cariri ${ }^{31}$ no Ceará e dados de de João Pessoa, capital da Paraíba. Nas entrevistas das amostras paulistana e ludovicense aqui analisadas, encontraram-se instâncias dos seguintes verbos:

Achar

(61) S1: o moleque joga muito né... [acho] [que é um que vai ter futuro na família] né... (SPM1B-NicolauS.)

(62) S1: por mais que em qualquer lugar tenha/seja perigoso mas [eu acho] [que aqui em São Luís esteja ficando cada vez mais perigoso] (SLM1SLúcioG.)

\section{Pensar}

(63) S1: aqui em São Paulo uma vez levaram meu celular mas [eu pensei] [que era brincadeira] (SPF3S-VaniaD.)

(64) S1: além de tirar essas pessoas da rua [penso] [que elas pudessem ter estudo] alguma coisa assim. (SPF1S-IsadoraM.)

Gostar

(65) S1: além de tirar essas pessoas da rua [penso] [que elas pudessem ter estudado] alguma coisa assim. (SPF1S-IsadoraM.)

(66) S1: então [ele sempre gostou] [que eu tivesse algum tipo de atividade intelectual]. (SPM3S-NiltonR.)

31 A região do Cariri é, de acordo com Carvalho (2007), uma microrregião situada ao sul do estado do Ceará. Para a pesquisa foram realizadas entrevistas nas sete principais cidades que compõe aquela área (Barbalha, Nova Olinda, Juazeiro, Várzea Alegre, Altaneira e Mauriti). 


\section{Supor}

(67) S1: [suponhamos] [que você veio] com dez anos do de Curitiba... e está aqui já há vinte aí não sei a pessoa se adapta aqui à cidade né. (SPM3BRodolfoR).

(68) S1: [vamo supor] [que) [eu te recebesse hoje] falava "ah... ai meu deus do céu essa menina vem fazer entrevista hoje não acredito"

(SPM2B-NelsonF.)

\section{Precisar (no sentido de "ter necessidade de")}

(69) S1: aí ela chegou pro meu tio "olha [preciso] [que ele trabalhe] não sei o quê"...

(SPM2S-JoséN.)

(70) S1: como meu pai trabalhava com os índios ele acabava sendo um pouco de tudo inclusive médico porque [eles precisavam] [que alguém ajudasse eles em muitas questões] (SLM3B-EmersonM.)

\section{Querer}

(71) S1: eu gosto de São Luis [eu quero] [que meu filho cresça aqui]. (SLM2B-JoséM.)

(72) eu acho legal o que e o governo tá fazendo essa coisa do acesso na universidade [eu quero mesmo] [que todo mundo entra na faculdade] acho uma ideia legal (SLF1B-MariaF.)

\section{Acreditar}

(73) D1: e olhando pra mim você diria que eu sou daqui de São Paulo? S1: $\operatorname{sim} . .$. não sei... [acredito] [que você seja] daqui mesmo.

(SPM1B-DalsonO.)

(74) D1: Eh D. Z. a senhora vê assim diferenças entre maranhenses e paulistanos assim no modo de falar por exemplo?

S1: não [eu não acredito] [que tem] eu não vejo (SLF3S-ZafiraS.)

\section{Imaginar}

(75) S1: quando a gente termina a educação fundamental [eu imagino] [que a gente não esteja ainda eh eh amadurecido] né

(76) S1: [nunca imaginei] [que eu poderia sair do Brasil] [que eu pudesse conhecer um outro país]. (SPF1S-SilviaB.) 


\subsubsection{Tempo Verbal da Oração Principal}

A hipótese que se testa com esse grupo de fatores é se tempos verbais no passado favorecem a ocorrência do subjuntivo. Poplack (1992), Oliveira (2007) e Carvalho (2007) incluíram esse grupo em suas análises e confirmaram tal hipótese. Grimm (2012), por outro lado, verificou que esse grupo não se mostrou estatisticamente relevante para a sua amostra. Carvalho (2007) explica que, em geral, verbos no passado tendem a exprimir significado de desejo, volição, e, portanto, "temporalidade prospectiva", contexto prototípico de uso da forma subjuntiva.

Ressalta-se que esse grupo de fatores é específico para o conjunto de dados de orações subordinadas substantivas.

\section{Presente}

(77) S1: o bairro onde eu moro é um bairro bem tranquilo é um bairro mais residencial do que comercial ah pelo menos a parte onde eu moro mas... [eu não acho] [que tenha muito de melhor do que outros bairros]... (SLM1S-EduardoE.)

(78) S1: [suponhamos] que você veio com dez anos do do de Curitiba]... e está e/ aqui já há vinte aí não sei a pessoa se adapta aqui à cidade né.

(SPM3S-RodolfoR.)

\section{Pretérito}

(79) S1: quando eu era mais novo... eh... [eu sempre achava] [que era assim]... aquela vida que eu levava na Madre Deus... eh... era o que eu tinha de mais... eh... era a única coisa que tinha... mas aí eu cresci e vi que tinha mais do mundo... (SLM1B-MarcosO.)

(80) S1: [eu sempre desejei] [que ela tivesse sucesso] nas ideias nos planos dela. (SPM2B-NelsonF.)

Futuro

(81) S1: o modo de se vestir né mais... eh personalista [eu diria] [que você é uma paulistana universitária]. (SPF3S-VaniaD.) 


\subsubsection{Tempo Verbal da Oração Subordinada}

Este grupo de fatores se relaciona ao anterior e, de maneira semelhante, visa a verificar se formas subjuntivas e indicativas tendem a ocorrer relativamente mais ou menos em algum dos tempos verbais. Em francês canadense, Poplack (1992) constatou que o tempo passado correlaciona-se com a seleção do modo subjuntivo. Quanto ao português brasileiro, Carvalho (2007), em seu trabalho com dados de fala da região do Cariri, verificou que tempos verbais no passado e no futuro são os que mais se correlacionam com a forma do subjuntivo na oração subordinada.

Perini (1995) explica, em seu estudo sobre das condições formais e semânticas dos modos verbais em português, que o tempo verbal da oração subordinada, principalmente no passado, é um importante fator para o uso do modo subjuntivo na subordinação.

\section{Presente}

(82) S1: sempre que eu posso eu vou pro interior dos meus pais [se é época de carnaval então] é melhor ainda (SPM1S-GuilhermeV.)

(83) D1: e a senhora acha que as pessoas devam continuar trabalhando mesmo se elas têm muito dinheiro?

S1: $\operatorname{sim} . .$. claro que sim... e [eu espero] [que todas as pessoas pensem assim como eu]... (SLF3S-ElisangelaS.)

(84) S1: como emprego tá dificil pra todo mundo tem gente eh hoje em dia assim você faz qualquer coisa [que te favorece] (SPM2S-JoséN.)

\section{Pretérito}

(85) S1: minha mãe nunca deixou a gente com adjunto [ela não gostava] [que a gente ia pra rua] (SLF3B-SuzanaC.)

(86) S1: eu tinha um professor que [se eu perguntasse alguma coisa pra ele que não tava correto] ele não respondia (SPM2S-JoséN.)

(87) S1: como emprego tá dificil pra todo mundo tem gente eh hoje em dia assim você faz qualquer coisa [que te favorece] (SPM3S-NiltonR.) 
Futuro

(88) S1: eu tinha um professor que [se eu perguntasse alguma coisa pra ele que não tava correto] ele não respondia (SPM2S-JoséN.)

(89) S1: em São Paulo o problema é qualificação tem que ir pra São Paulo a pessoa [que for com qualificação] (SLM3S-JoãoK.)

\subsubsection{Grau de Assertividade da Oração}

Esse grupo de fatores, específico para os conjuntos de dados de subordinadas substantivas e relativas, visa a verificar se há correlação entre a presença um elemento negativo (não, nunca, jamais etc) - na oração principal, na subordinada, ou em ambas - e a ocorrência do subjuntivo na subordinada.

Pimpão (1999; 2012) mostra que a negação, sobretudo na oração matriz, favorece o emprego do subjuntivo. Segundo Neves (2000), o elemento de negação na oração principal gera um efeito de compatibilidade com o valor de incerteza, o que leva à noção de subjuntividade no período composto por subordinação. A pergunta que se faz com este grupo de fatores é se, nesses casos, formas subjuntivas ou formas indicativas tendem a ocorrer mais - em São Paulo e em São Luís.

No que diz respeito a elementos negativos na oração subordinada, Rocha (1997) observou em seu estudo com dados de fala das cidades de Brasília e Rio de Janeiro que formas subjuntivas ocorrem relativamente mais, também neste caso, em orações que apresentam algum elemento de negação.

Dessa forma, são quatro os casos possiveis:

(i) ausência de elementos de negação na oração principal $e$ na oração subordinada; 
(90) S1: eu gosto mais de ambientes [em que eu possa conversar com a pessoa] (SLM1S-EduardoE.)

(91) S1: eu gosto de lugares [em que a gente pode passar mais tempo conversando]... (SLM1S-EduardoE.)

(92) [eu queria] [que minha pele combinasse com a cor do meu cabelo] (SLM1S-EduardoE.)

(93) [eu queria] [que minha pele combinasse com a cor do meu cabelo] (SLM1S-EduardoE.)

(94) [eu duvido] [que algum deles faz melhor do que ela tem feito] mas a gente só quer reclamar (SLF1S-TatianaJ.)

(ii) ausência de negação na oração principal, presença de negação na oração subordinada;

(95) S1: é dificil encontrar uma coisa [que não não goste daqui] entendeu?

(SPM2B-GilsonS.)

(96) S1: a gente sempre precisa por um limite [que não não desgasta a gente] sabe (SLF2B-AdalbertaC.)

(97) S1: [eu acredito] [que o Brasil não vai mudar nunca]

(SLM1B-MarceloO.)

(98) S1: toda vez que a minha mãe dizia [eu quero] [que não esteja no lugar que eu deixei] eu tremia na base só de pensar no que podia acontecer

(SLM1B-LuisJ.)

(iii) presença de negação na oração principal, ausência na oração subordinada;

(99) S1: não tem pássaros [que voam] pra capturar isso foi o pastor da universal que está no facebook dizendo na igreja (SLF1B-MariaF.)

(100) S1: não não tem um sotaque assim [que eu mais gosto] eu valorizo todos os modos que se fala (SLF1B-ValériaD.)

(101) S1: às vezes eu fico me perguntando [eu não acredito] [que esse tipo de coisa só aconteça aqui em São Luís]... (SLF1B-MariaF.)

(102) S1: [eu não gosto] [que eles falam mal de paulista] eu não gosto (SPM3B-EduardoK.) 
(iv) negação na oração principal $e$ na oração subordinada.

(103) S1: [eu não gosto] [que ninguém me imponha alguns valores que eu detesto] (SLF2S-AndreiaL.)

(104) S1: eu tenho trauma de roupa de folho [eu não gosto] [que ninguém me dê roupa de folho] (SLF2B-MarianeR.)

(105) S1: não tem fim de semana não tem feriado [que ele não trabalha] não tem nada fora que tudo o que der errado cai nas \{costas do diretor\} (SPF3S-NeideE.)

(106) S1: eu acho que não em São luís não tem ninguém [que não goste] da cidade eu acho que todo mundo gosta dela (SLF2B-GláuciaP.)

\subsubsection{Distância entre o Pronome Relativo e a Forma Verbal em Foco}

Este grupo de fatores diz respeito apenas às subordinadas adjetivas relativas - cuja adjunção a um substantivo da oração principal é feita com o pronome que.

A hipótese que justifica tal grupo de fatores reside na consideração de que quanto maior a distância entre o pronome relativo e a forma verbal da oração subordinada, maior a probabilidade de ocorrência de uma forma verbal indicativa. Por outro lado, quanto mais próxima a forma verbal estiver do relativo que, maiores as chances de que tal forma seja subjuntiva. Esta hipótese se baseia numa série de trabalhos (CARVALHO, 2007; ALVES, 2009; GRIMM, 2012) em que se verificou que o relativo que é favorecedor do emprego do subjuntivo.

Dentre os vários trabalhos sobre este tema desenvolvidos com dados do português brasileiro, Alves (2009) é o único que chegou a testar tal hipótese. A análise de seus dados, extraídos de textos do século XVI, revela que o modo indicativo é um pouco favorecido (peso relativo .53) nos casos em que a forma verbal da subordinada está mais distante do pronome relativo. 
Se estiver correta a hipótese de que o subjuntivo é relativamente mais empregado por ludovicenses do que por paulistanos, será interessante verificar se essa relação da forma verbal com o pronome que apresenta correlações semelhantes ou divergentes nas duas amostras.

Os dados foram codificados da seguinte maneira:

(i) forma verbal da subordinada adjacente ao pronome relativo

(107) S1: sou cismada com qualquer pessoa [que encosta do meu lado] (SPF1B-MilenaF.)

(108) S1: muita gente [que quiser ganhar dinheiro] pode vim pra São Luís que ganha. (SLM3S-AndersonR.)

(ii) presença de um elemento entre o pronome relativo e a forma verbal

(109) S1: aqui a pessoa que tem um espaço que possa servir de bar ele vai ganhar dinheiro toda semana por que ele vai botar o som dele na altura [que ele quiser] (SLM2S-PedroH.)

(110) S1: [não teve assim uma modificação assim gritante] [que você fala assim] nossa como mudou da minha época (SLF3S-ElisangelaS.)

(iii) presença de dois elementos entre o relativo e a forma verbal

(111) S1: era naquele momento [que a cabeça estava começando a tomar consciência] (SPM1B-EvandroO.)

(112) S1: quando a gente faz uma pergunta [que ela não sabe responder] também dá pra saber que não é daqui. (SLM2S-InácioS.)

(iv) presença de três ou mais elementos entre o relativo e a forma verbal

(113) S1: cada um tem que viver a sua vida da forma [que o homem com homem ou a mulher com a mulher eh acha melhor] (SLM3SPabloS.)

(114) S1: eu acho que tem uma grande importância que todo que todo [que todo o jovem saiba o que existe] (SPF3B-LucianaM.) 


\subsubsection{Tipo de Subordinador}

De interesse para as orações subordinadas adverbiais, este grupo de fatores visa a verificar se certas conjunções subordinativas, relativamente mais do que outras, favorecem o emprego do indicativo. São muito variados os dados e, no sentido de possibilitar a análise quantitativa, muitos casos foram amalgamados entre si. A discussão em torno disso é oportunamente feita no capítulo 5, quando da apresentação dos resultados. Abaixo, contudo, seguem alguns exemplos dos tipos de dados mais frequentes nas amostras.

$\mathrm{Se}$

(115) S1: [se você quisesse namorar] [tinha que ir no pai pra pedir]... (SPM1B-NicolauS).

(116) S1: tenho umas tias que é uma figura quando se reúne todo mundo é uma loucura aí você chega aqui [você fica tonto completamente] [se você não está acostumado]...

Embora

(117) S1: não eu eu eu ia no grupo escolar [embora perdi dois anos] então com doze ano eu tava no segundo ano (SPM3B-EduardoK.)

(118) D1: então o senhor mora em um bairro bem servido. $\mathrm{S} 1$ : acredito que sim [embora seja um conjunto habitacional]

(SLM3S-PabloS.)

(119) S1: minha mãe cuidava da gente então nós estudávamos com ela até nós estudamos com ela até a quarta série ela tomando a lição pessoalmente... até a quarta série... às vezes [talvez eu não lembro direito] eu tenho certeza de que até a quarta série ela tomava a lição acompanhando bem de pró/ bem bem de perto... [talvez na quinta sexta série ela tenha deixado]. (SLM1S-EduardoE.)

Tomara que

(120) S1: eu sempre acho assim que pra qualquer pessoa a gente tem que pensar [tomara que os planos delas dão certo] (SLF1B-MariaF.)

\section{Enquanto}

(121) S1: eu sempre fico pensando que [enquanto eu estivesse em outro lugar] [eu ia estar com saudade daqui] (SPM3B-WaldemarS.) 
Antes que

(122) D1: posso? eu vou te dar uma lista de palavras tu pode ler pra mim? $\mathrm{S} 1$ : eu não enx/... porque eu não leio assim eu só leio só se eu tiver meu óculos... mas [vamos] [antes que o sol vá embora] (SLF3BGrazielaD.)

\section{Mesmo que}

(123) S1: [nenhum ser humano tem o direito de tirar a vida do outro] né? [mesmo que ele seja esteja alto posto lá] né? (SM3B-EduardoK.)

(124) S1: [eu cuido da minha mãe] entendeu [mesmo que minha mãe não me deu nada na vida] entendeu

Não que/Não é que

(125) S1: você vai ao shopping você encontra com certeza vai na praça de alimentação você sempre encontra algum conhecido mas [não que a gente reúna pra se co/ pra se ver] entendeu (SPF1B-RenataC.)

(126) S1:eu cuidei dos gatinhos durante toda minha infância depois eu não quis mais saber

D1: passou a desgostar

S1: ah [não é que não gostava mais mas é que não tinha mais carinho... (SLM1S-EduardoE.)

\section{A não ser que}

(127) S1: o pessoal se relaciona bem... [a não ser que tenha alguém] que seja muito assim religioso judeu que não queria se misturar tal

(SPM1S-GuilhermeV.)

(128) S1: a mulher tem que fazer o serviço de casa e nós temos que manter o que é feito por ela [a não ser que o cara também ajuda]

(SLM3B-NeilsonS.)

Por mais que

(129) S1: o filho não vai pra escola eu acho que [por mais que a criança não goste] [é fundamental] tem que ficar em cima...

(SPM1S-GuilhermeV.)

\section{Desde que}

(130) S1: a Constituição me garante o direito de me manifestar [desde que não use de anonimato] e eu posso expressar meu desapontamento com ela enquanto governadora... (SLM1S-PedroH.) 
De modo que

(131) S1: você abre assim uma porta muito larga pra essa pessoa [de modo que ela volta a viver] ela volta a poder pagar as dividas dela

(SPM2S-RobertoM.)

\subsubsection{Ordem das Orações no Período Composto por Subordinação}

Este grupo de fatores diz respeito às orações subordinadas adverbiais, cuja posição é variável (KATO e TARALLO et alii, 1993), embora, de acordo com Hirata (1999), nos casos de orações condicionais (sobretudo com se), prefira-se, em português, pela colocação da oração condicionada (prótase) antes da oração condicionante (apódose). A pergunta é se haveria alguma correlação entre a posição variável da oração subordinada no período composto e o emprego de formas indicativas ou subjuntivas - a partir do exame qualitativo de exemplos como os que se seguem.

(i) Oração Condicionante (Prótase) seguida da Condicionada (Apódose)

(132) S1: [se fosse pra eu sair daqui da Vila Matilde] [...] [eu teria que vender a minha casa aqui] (SPM2S-RobertoM.)

(133) S1: [se cada subprefeitura conseguia fazer a sua parte] o mais ( $x x x)$ soubesse coordenar tudo isso e aí o governador ( $\mathrm{xxx})$ até chegar lá em cima [haveria menos problemas e menos reclamação]

(SPF3B-LucianaM.)

(134) S1: a minha mãe era muito rígida comigo

D1: assim como? você apanhava?

S1: não não mas ela era rígida [talvez ela fazia isso comigo] não sei talvez pelo [por eu ter um problema de vista] (SPM1B-EvandroO.)

(135) eu devo dizer que [talvez eu precise me organizar] [pra ter um pouco mais de sossego] (SLM2B-JoaquimM.)

(ii) Oração Condicionada (Apódose) seguida da Condicionante (Prótase)

(136) S1: eu acho que [eu só queria sair do bairro que eu moro] [se eu fosse morar na praia] (SPF3B-LucianaM.) 
(137) S1: [eu faria um condomínio fechado com casa pra cada um dos meus filhos] [se Deus me desse essa graça] porque Deus não gosta de jogo (SLF3B-AnaC.)

(138) S1: a gente sempre precisa de auxilio ahn médico essas coisa mas [se tu precisar de um serviço mais caro] [talvez aí depende do plano de saúde] (SLF3B-DayseR.)

(139) S1: não sei mas [esse monte de acidente de carro nas estrada] [talvez seja muita falta de educação no trânsito]... e isso é péssimo

(SLM1S-SofiaS.)

(140) D1: mas tu achas errado o homem depender da mulher?

S1: não eu acho normal [eu sempre digo que isso é normal em conversas com meus amigos] [embora muita gente aqui acha que eu acho errado] eh acha que eu penso errado (SLM1S-EduardoE.)

(141) S1: [preciso priorizar muitas coisas na minha vida] como o estudo [embora seja bastante dificil ter foco] (SLM2S-CláudioM.)

De acordo com a discussão de natureza qualitativa dos grupos de fatores linguísticos, o quadro abaixo resume aqueles que foram incluídos nas análises de cada conjunto de dados - conjuntos esses que se definem, conforme se definiu no capítulo 1, pelas três diferentes estruturas de subordinação.

Quadro 5: Grupos de Fatores Linguísticos para cada Conjunto de Dados

\begin{tabular}{ll}
\hline Conjunto de Dados & Grupos de Fatores \\
\hline Orações Adverbiais & $\begin{array}{l}\text { Tipo de subordinador } \\
\text { Tempo Verbal da Oração Subordinada } \\
\text { Ordem das Orações no Periodo }\end{array}$ \\
\hline \multirow{2}{*}{ Orações Subordinadas } & Verbo da Oração Principal \\
Substantivas & Tempo Verbal da Oração Principal \\
& Tempo Verbal da Oração Subordinada \\
& Grau de Assertividade da Oração \\
\hline \multirow{3}{*}{ Orações Relativas } & Tempo Verbal da Oração Subordinada \\
& Distância entre o Pronome Relativo e a Forma Verbal \\
& Grau de Assertividade da Oração \\
\hline
\end{tabular}




\section{CAPÍTULO 4 ANÁLISES QUANTITATIVAS}

No capítulo 1, foram definidos os contextos em que formas do subjuntivo e do indicativo são possíveis - seja como variantes de uma variável, seja "simplesmente como" formas alternantes. No capítulo anterior, discutiram-se os grupos de fatores que hipoteticamente se correlacionam aos empregos dessas formas. No presente capitulo, apresentam-se os resultados das análises quantitativas das ocorrências dessas formas, nos diferentes contextos de subordinação, extraídas das 72 entrevistas sociolinguísticas $(36 \mathrm{com}$ paulistanos, $36 \mathrm{com}$ ludovicenses).

A análise quantitativa é feita da perspectiva do modo indicativo (ou seja, esta forma é estipulada como valor de aplicação nas análises estatísticas), já que o olhar aos dados se dá a partir da hipótese inicial de que o indicativo estaria se sobrepondo ao subjuntivo em certos casos; em outras palavras, pretende-se verificar se o uso do indicativo está aumentando em contextos nos quais o subjuntivo é forma possivel ou "esperada".

Nas análises cujos resultados são reportados abaixo, além dos grupos de fatores sociais que estratificam a amostra (cidade de origem, sexo/gênero, faixa etária e escolaridade), foram incluídos, conforme resumo o Quadro 5 ao final do capítulo anterior, grupos de fatores linguísticos específicos para cada conjunto de dados. Além de análises específicas para as orações adverbiais, substantivas e relativas (separadamente), realiza-se uma análise geral com os três conjuntos de dados, na intenção de verificar a correlação entre o emprego das formas e os grupos de fatores localidade e o tipo de oração subordinada. 


\subsection{A VARIEDADE PAULISTANA}

A tabela abaixo reitera como as ocorrências das formas em foco (subjuntivo e indicativo) se distribuem, na amostra paulistana, entre Orações adverbiais, Orações subordinadas substantivas e Orações relativas.

Tabela 4: Distribuição geral dos dados - São Paulo

\begin{tabular}{cccccc}
\hline $\begin{array}{c}\text { Orações } \\
\text { Subordinadas }\end{array}$ & $\begin{array}{c}\mathbf{N} \\
\text { Indicativo }\end{array}$ & $\mathbf{\%}$ & $\begin{array}{c}\mathbf{N} / \% \\
\text { Subjuntivo }\end{array}$ & $\mathbf{\%}$ & Total \\
\hline Adverbiais & 172 & 29 & 414 & 71 & 586 \\
Substantivas & 96 & 53 & 85 & 47 & 181 \\
Relativas & 127 & 52 & 115 & 48 & 242 \\
Total & & 39,1 & & 69,9 & 1009 \\
\hline
\end{tabular}

No geral, a tabela acima mostra que o indicativo não é mais frequente que o subjuntivo em todos os contextos (representando, aliás, “apenas" 29\% das ocorrências em orações adverbiais).

\subsubsection{Orações Adverbiais}

Nenhum dos grupos de fatores sociais (sexo/gênero dos informantes, sua faixa etária, sua escolaridade) foi selecionado como estatisticamente relevante, para as orações adverbiais na amostra paulistana. A tabela 5 apresenta a distribuição dos dados nesses fatores, bem como pesos relativos obtidos de análises one-level. 
Tabela 5: Orações adverbiais e Fatores Sociais - São Paulo

\begin{tabular}{ccccc}
\hline Grupo & Fatores & $\begin{array}{c}\text { Indicativo/ } \\
\text { Total }\end{array}$ & $\%$ & Peso Relativo \\
\hline \multirow{4}{*}{ Faixa Etária } & $18-35$ & $70 / 239$ & 30 & {$[.49]^{32}$} \\
& $36-59$ & $56 / 177$ & 31 & {$[.52]$} \\
& $60 \mathrm{ou}+$ & $46 / 170$ & 27 & {$[.47]$} \\
& & & & \\
Sexo/Gênero & Feminino & $63 / 209$ & 30 & {$[.50]$} \\
& Masculino & $109 / 377$ & 29 & {$[.49]$} \\
Escolaridade & Superior & $98 / 300$ & 32 & {$[.54]$} \\
& Colegial & $74 / 286$ & 26 & {$[.45]$} \\
Total de & & $172 / 586$ & 30 & \\
ocorrências & & & & \\
\hline Input: 0.293 & Significância: 0.981 &
\end{tabular}

Os resultados para faixa etária revelam que, para as orações adverbiais, não há indício de mudança em curso em tempo aparente, com aumento gradativo de ocorrências do indicativo. Não há, tampouco, preferência estatisticamente significativa dessa forma por qualquer uma das faixas etárias. Observa-se, contudo, um favorecimento do indicativo entre os informantes da segunda faixa etária - normalmente mais sensivel às pressões do "mercado linguístico" (BOURDIEU, 1991). Como este grupo de fatores não foi selecionado pela análise estatística, não convém interpretar tal resultado como um indício de que formas indicativas estariam gozando de algum prestígio encoberto na comunidade; entretanto, como se trata de um peso relativo que está acima do ponto neutro (diferentemente das duas outras faixas etárias), vale ter este como um resultado interessante, sobretudo em análises futuras, com dados de possiveis novas amostras que possam vir a ser coletadas.

Quanto a sexo/gênero, os resultados aqui se assemelham aos de outros estudos sobre variáveis "além" do nível fonético-fonológico - tais

32 Os colchetes [ ] indicam que o grupo de fatores não é estatisticamente relevante. 
como Pimpão (2012), sobre a expressão do modo subjuntivo em amostras de fala e escrita, nas cidades de Lages e Florianópolis; Carvalho (2007), sobre a expressão do modo subjuntivo em dados de fala da cidade de Cariri, no Ceará; Oushiro (2011), sobre a variação no emprego das interrogativas-Q em São Paulo. Conforme tem sido divulgado na vasta literatura variacionista sobre o tema, mulheres tendem a empregar as formas mais socialmente prestigiadas e a liderar certos processos de mudança. O fato de que mulheres e homens não se diferenciam entre si, no que diz respeito ao emprego das formas do subjuntivo e do indicativo nas orações adverbiais, pode significar que o subjuntivo já não detém prestígio social.

Também é interessante o fato de que Escolaridade não tenha sido selecionado como grupo de fatores estatisticamente relevante. Neste caso, é possivel que isso se deva ao fato de que não há uma diferenciação muito grande entre os dois níveis de escolaridade da amostra (médio e superior). Seria conveniente, em outro estudo, verificar se tal resultado permaneceria com uma amostra que incluísse sujeitos com nível mais baixo (fundamental, por exemplo).

No seu conjunto, esses resultados indicam que, socialmente, não há diferenciação relevante entre grupos de informantes. No geral, os paulistanos empregam mais a forma do subjuntivo, nas orações subordinadas adverbiais.

Quanto às hipóteses linguísticas, foram testados os grupos de fatores tempo verbal da oração subordinada, tipo de subordinador e ordem das orações no periodo. Este último grupo não foi selecionado como estatisticamente relevante. 
Tabela 6: Orações adverbiais e Fatores Linguísticos - São Paulo

\begin{tabular}{ccccc}
\hline Grupo & Fatores & $\begin{array}{c}\text { Indicativo/ } \\
\text { Total }\end{array}$ & $\%$ & Peso \\
\hline $\begin{array}{c}\text { Tempo } \\
\text { Verbal da } \\
\text { Oração } \\
\text { Subordinada }\end{array}$ & Presente & $133 / 218$ & 62 & .88 \\
& Pretérito/Futuro & $39 / 368$ & 10 & .23 \\
$\begin{array}{c}\text { Tipo de } \\
\text { Subordinador }\end{array}$ & Outros & $119 / 407$ & 29,2 & .60 \\
Total de & & $53 / 179$ & 29,8 & .26 \\
ocorrências & & $172 / 586$ & 30 & Range: 34 \\
\hline
\end{tabular}

Input: 0.293 Significância: 0.00

A Tabela 6 indica que, diferentemente do que se observou quanto aos grupos de fatores sociais, há grande diferenciação no emprego das formas do subjuntivo e do indicativo, nas orações subordinadas adverbiais, a depender do tempo verbal e do tipo de subordinador.

Com verbos no presente, é maior a tendência de emprego do indicativo, ao passo que no pretérito e no futuro (amalgamados nessa análise por conta do baixo número de ocorrências (39) casos de indicativo, num total de 368 dados) o subjuntivo tende a ser mais empregado. Em outras palavras, o subjuntivo é forma desfavorecida no presente e favorecida nos outros tempos que ocorrem na amostra.

Quanto ao grupo tipo de subordinador, cada um foi individualmente codificado (conforme descreveu-se no capitulo anterior), mas vários deles foram amalgamados, também em razão do baixo número de ocorrências (exceto se). Os resultados indicam que, nas adverbiais com se, o indicativo é favorecido - diferentemente do que se observa para o conjunto de orações com outros subordinadores (como embora, etc). 
Quando os outros subordinadores são observados separadamente, nota-se que o indicativo é pouco frequente - conforme mostra a Tabela 7 abaixo, que mostra a distribuição dos dados para alguns deles ${ }^{33}$. Conjunções e locuções conjuntivas tais como embora, talvez, a não ser que, como se, etc, não parecem favorecer o emprego do indicativo. A única exceção é quando, em cujas quatro ocorrências figuram formas indicativas, a exemplo de (142) abaixo.

(142) S1: vamos ter que gravar é?

D1: sim como eu te falei pelo telefone

$\mathrm{S} 1$ : não tudo bem mas [quando ouço a minha voz] [eu não vou gostar] e nem tu também

D1: fica tranquilo

(SLM1B-MarcosS.)

Em outras palavras, há variação, mas o subjuntivo ainda é preferido com esses outros subordinadores:

Tabela 7: Frequências do indicativo com outros subordinadores - São Paulo

\begin{tabular}{ccc}
\hline Subordinadores (exceto SE) & $\begin{array}{c}\text { Indicativo/ } \\
\text { Total }\end{array}$ & $\%$ \\
\hline embora & $4 / 12$ & 33 \\
talvez & $18 / 53$ & 34 \\
a não ser que & $1 / 14$ & 7 \\
como se & $3 / 21$ & 14 \\
quando & $4 / 4$ & 100 \\
Total & $26 / 100$ & \\
\hline
\end{tabular}

Assim, esses resultados mostram que, se há uma expansão dos empregos do indicativo (em vez do subjuntivo), ela tende a se dar com com se (muito embora o grupo faixa etária não tenha revelado um indício de mudança em progresso, para este conjunto de dados). Dito de outra maneira, o indicativo tende a ser relativamente menos empregado com os subordinadores menos frequentes na amostra, cujo uso é possivelmente mais marcado.

\footnotetext{
${ }^{33}$ Uma tabela completa com todos os subordinadores encontrados no corpus pode ser verificado no Apêndice B deste trabalho.
} 
Conforme mencionou-se anteriormente, o grupo ordem das orações no periodo não se revelou estatisticamente relevante. A Tabela 8 a seguir traz as distribuições de dados e pesos relativos fornecidos por uma análise one-level.

Tabela 8: Ordem de orações no periodo e emprego do Indicativo

\begin{tabular}{cccc}
\hline Ordem da Oração & $\begin{array}{c}\text { Indicativo/ } \\
\text { Total }\end{array}$ & $\%$ & P.R. \\
\hline $\begin{array}{c}\text { Apódose } \\
\text { (condicionada + } \\
\text { condicionante) } \\
\begin{array}{c}\text { Prótase } \\
\text { (condicionante + } \\
\text { condicionada) }\end{array}\end{array}$ & $51 / 156$ & 32 & {$[.52]$} \\
Total de ocorrências & $172 / 586$ & 28 & {$[.48]$} \\
\hline Input: 0.293 Significância: 0.193 & & \\
\hline
\end{tabular}

São mais frequentes no conjunto de dados os casos de prótase, mas a frequência de ocorrência do indicativo é praticamente a mesma nos dois tipos de ordenação entre condicionadas e condicionantes.

De um modo geral, portanto, quando se trata de orações adverbiais, o modo subjuntivo ainda é a forma mais recorrente na fala dos paulistanos, de acordo com essa amostra.

\subsubsection{Orações Subordinadas Substantivas}

Conforme vimos anteriormente, são vários os estudos sociolinguísticos sobre a alternância entre o subjuntivo e o indicativo nas orações substantivas encaixadas na posição de complemento verbal (BARBOSA, 2013; CARVALHO, 2007; OLIVEIRA, 2007; POPLACK, 1994; ROCHA, 1997). Em geral, esses trabalhos mostram a relevância das variáveis sexo/gênero, verbo da oração principal, grau de assertividade do período.

No presente trabalho, conforme mostra o quadro 5 ao final do capítulo 3 , os dados de orações subordinadas a um verbo foram 
codificados para sexo/gênero, faixa etária, escolaridade, verbo da oração principal, tempo verbal da oração principal, tempo verbal da oração subordinada e o grau de assertividade do periodo. Dentre eles, os que foram selecionados como estatisticamente significativos estão na Tabela 9:

Tabela 9: Fatores relevantes para a alternância indicativo/subjuntivo em subordinadas substantivas - São Paulo

\begin{tabular}{ccccc}
\hline Grupos & Fatores & $\begin{array}{c}\text { Indicativo/ } \\
\text { Total }\end{array}$ & $\%$ & P.R. \\
\hline $\begin{array}{c}\text { Verbo da Oração } \\
\text { Principal }\end{array}$ & Cognitivos & $88 / 122$ & 72 & .71 \\
& Volitivos/Factivos & $08 / 51$ & 12 & .12 \\
Faixa etária & $18-35$ & $47 / 66$ & 71 & .64 \\
& $36-59$ & $23 / 54$ & 42 & .36 \\
& 60 ou + & $26 / 61$ & 42 & .46 \\
Tempo verbal da & & & & Range: 28 \\
Oração Principal & Presente & $73 / 126$ & 56 & .53 \\
& Pretérito/Futuro & $23 / 55$ & 46 & .41 \\
Total & & & & Range: 12 \\
Input: 507 Significância: 0.032 & $96 / 181$ & & \\
\end{tabular}

Com verbos cognitivos (crer, pensar, lembrar, entre outros) é favorecido o emprego do indicativo. Apesar da assimetria entre os tipos de verbos no conjunto de dados (são bastante menos numerosas as ocorrências de verbos volitivos - tais como querer e desejar - e de verbos factivos - tais como lamentar e exigir), os resultados vão na direção daquilo que prescrevem algumas das gramáticas normativas (cf. ALI, 1966; CUNHA e CINTRA, 1985; BECHARA, 2005), que atribuem modo indicativo a subordinadas a verbos cognitivos e subjuntivo no caso de verbos volitivos que exprimam incerteza, dúvida, desejo.

${ }^{34}$ A lista de todos os verbos que ocorreram nas amostras está disponível no Apêndice A. 
Vale ressaltar, contudo, que as distribuições obviamente não são categóricas. Isto é, embora os dados se aproximem da prescrição, eles também indicam que há alternância de modos: também se emprega indicativo nas subordinadas a verbos volitivos e factivos, da mesma forma que se emprega subjuntivo nas subordinadas a verbos cognitivos.

Diferentemente do que se verificou no item anterior para as subordinadas adverbiais, faixa etária é uma variável relevante para a alternância entre modos nas subordinadas a verbos. Enquanto os mais idosos e falantes da faixa intermediária se assemelham no desfavorecimento do indicativo, os mais novos favorecem tal forma.

Figura 1: Tendência de emprego do Indicativo de acordo com a Faixa Etária São Paulo



Esses resultados, portanto, configuram um indicio de mudança em curso em tempo aparente, em favor do indicativo orações subordinadas a verbos. Considerando-se que as tendências (pesos) para os mais velhos e falantes da faixa intermediária se assemelham, uma nova análise multivariada foi feita, amalgamando-se essas duas faixas. Entretanto, os padrões mantiveram-se os mesmos daqueles indicados na Tabela 9, como os mesmos grupos de fatores selecionados e mesmas tendências. Isso reforça, então, o significado da relevância da faixa etária para este conjunto de dados. 
Finalmente, quanto ao tempo verbal da oração principal, verificase que, também neste conjunto de dados, no presente é maior a tendência de emprego do indicativo, relativamente àqueles casos em que o tempo verbal da oração principal é o pretérito ou o futuro. Esses resultados se assemelham àqueles reportados por Poplack (1994), que analisou o francês falado na região de Otawa-Hull; por Carvalho (2007), que analisou dados da variedade cearense do PB; e por Wherritt (1977), que analisou o português falado em diversas cidades do interior paulista. Observe-se, contudo, que o range desse grupo (a distância entre o peso mais alto e o peso mais baixo) é menor que o dos outros dois que foram selecionados - de modo que a força da correlação entre tempo verbal da oração principal e tendência de uso do indicativo no lugar do subjuntivo é menor do que a do tipo de verbo e da faixa etária.

A fim de oferecer uma visão mais abrangente das distribuições dos dados, a Tabela 10, traz os grupos de fatores que não foram selecionados como estatisticamente relevantes (os pesos relativos indicados foram obtidos de análises one-level): 
Tabela 10: Grupos de Fatores não selecionados nas análises das subordinadas substantivas - São Paulo

\begin{tabular}{ccccc}
\hline Grupos & Fatores & $\begin{array}{c}\text { Indicativo/ } \\
\text { Total }\end{array}$ & $\%$ & P.R. \\
\hline Sexo/Gênero & Masculino & $64 / 109$ & 58 & {$[.55]$} \\
& Feminino & $32 / 72$ & 44 & {$[.41]$} \\
Escolaridade & Superior & $56 / 100$ & 56 & {$[.52]$} \\
$\begin{array}{c}\text { Tempo Verbal da } \\
\text { Oração }\end{array}$ & Presente & $66 / 119$ & 55 & {$[.46]$} \\
$\begin{array}{c}\text { Subordinada } \\
\text { Pretérito/Futuro }\end{array}$ & $30 / 62$ & 48 & {$[.52]$} \\
$\begin{array}{c}\text { Grau de } \\
\text { assertividade do } \\
\text { periodo }\end{array}$ & Negação em & & & {$[.45]$} \\
alguma posição & $23 / 56$ & 56 & {$[.53]$} \\
$\begin{array}{c}\text { Totrirmação na } \\
\text { ocorrências de }\end{array}$ & na subordinada & $52 / 140$ & 52 & {$[.49]$} \\
\hline Input: O.573 Significância: 0.014 & & & \\
\hline
\end{tabular}

Input: 0.573 Significância: 0.014

Para sexo/gênero e escolaridade, talvez possa-se explicar sua não correlação a esse caso de alternância entre o indicativo e o subjuntivo por uma mudança na avaliação social dessas formas, concomitante à mudança em curso (em tempo aparente), com o aumento do emprego do indicativo. Nos dados, são de fato comuns ocorrências como a que se transcreve abaixo (de uma entrevista com uma mulher com nível superior de escolaridade).

(143) tem uma moça que lava carro de fim de semana... ela trabalha a semana toda e de fim de semana ela pega uns carros pra lavar então ela sempre vai lá em casa "ai [você não quer] [que eu lavo o carro]" lava o meu carro pra mim lavo o carro

(SPF2S-ArianeG.)

Com relação ao tempo verbal da subordinada, vários estudos afirmam que é com o tempo verbal da oração matriz que a seleção dos modos se correlaciona. Os resultados aqui apresentados se equiparam, então, aos de outros trabalhos. 
Quanto ao grau de assertividade do periodo, Carvalho (2007) e, Almeida (2010) mostram que o verbo achar precedido de elementos negativos na oração matriz tende a favorecer o emprego do subjuntivo. O fato de que tal grupo não tenha sido selecionado nessa análise apesar do baixo número total de dados, leva a crer que, em São Paulo, a negação não é um fator de retenção do subjuntivo (considerando-se a hipótese, de certa forma confirmada pela grupo faixa etária, de que o indicativo estaria ganhando espaço em contextos de emprego do subjuntivo).

\subsubsection{Orações Relativas}

Conforme discutiu-se em capítulos anteriores, outro contexto em que se observa a alternância entre os modos subjuntivo e indicativo é o das orações relativas, ou seja, quando orações estão na posição de um adjunto ou de um complemento nominal:

(91) na verdade, ele tem [medo de que eu vou embora]

(92) quero comprar um apartamento [com janela que dê pra rua]

$\mathrm{Na}$ análise desse conjunto de dados, foram incluídos os mesmos grupos de fatores sociais das análises reportadas nos itens anteriores (sexo/gênero, escolaridade e faixa etária), bem como os grupos de fatores linguísticos tempo verbal da oração subordinada, distância entre o pronome relativo e a forma verbal em foco e a ordem das orações no periodo. A Tabela 11 elenca aqueles que se revelaram estatisticamente significativos: 
Tabela 11: O indicativo em orações relativas - São Paulo

\begin{tabular}{ccccc}
\hline $\begin{array}{c}\text { Grupos de } \\
\text { Fatores }\end{array}$ & Fatores & $\begin{array}{c}\text { Indicativo/ } \\
\text { Total }\end{array}$ & $\%$ & P.R. \\
\hline $\begin{array}{c}\text { Tempo Verbal da } \\
\text { Oração } \\
\text { Subordinada }\end{array}$ & Presente & $106 / 167$ & 63 & .60 \\
& Pretérito/Futuro & $21 / 75$ & 28 & .27 \\
Faixa Etária & $18-35$ & $70 / 100$ & 70 & Range: 33 \\
& $36-59$ & $29 / 73$ & 39 & .64 \\
& 60 ou + & $28 / 79$ & 40 & .38 \\
Sexo/Gênero & & & & .41 \\
& Masculino & $81 / 138$ & 58 & Range: 26 \\
& Feminino & $46 / 104$ & 44 & .57 \\
Total de & & & & Range: 17 \\
ocorrências & & $127 / 242$ & & \\
\hline Input:0.525 Significância:0.01 & & &
\end{tabular}

Diferentemente do que se constatou para as subordinadas substantivas, para as relativas há forte correlação entre a alternância subjuntivo/indicativo e o tempo verbal da subordinada, com alta tendência de emprego do indicativo no presente.

Com relação à faixa etária, verifica-se fenômeno semelhante ao que se observou para as subordinadas substantivas: o indicativo é favorecido entre os mais jovens e desfavorecido entre os falantes da segunda e da terceira faixa etária. Assim, mais uma vez, temos um indício de mudança em curso, em tempo aparente, na direção do indicativo.

Interessantemente, para esse conjunto de dados, há uma diferenciação significativa entre homens e mulheres (algo que não se observou nos casos anteriores): os primeiros favorecem o indicativo. Em outras palavras, as mulheres tendem a evitar o indicativo (portanto, tendem a reter o subjuntivo) nas orações relativas. Isto se assemelha com os resultados de outros trabalhos (Pimpão, 1999; 2012, Alves, 
2009), mas é curioso que o mesmo padrão não tenha se observado para as subordinadas adverbiais e substantivas.

É preciso deixar claro, no entanto, que se trata de conjuntos de dados com características estruturais bastante distintas, o que pode justificar padrões diferenciados para cada um deles entre os sujeitos. Além disso, como se pode observar em outros estudos, esse resultado não parece replicar um padrão do português. Meira (2006) analisou a fala de comunidades afrodescendentes no sul da Bahia e chegou a resultados diferentes. No trabalho dela, são os homens que "retêm" o subjuntivo, ao passo que as mulheres empregam relativamente mais o indicativo. Entretanto, a estratificação de sua amostra (sexo/gênero; três faixas etárias - 20 a 40, 41 a 60 e 60 anos ou mais) assemelha-se à deste trabalho; a maior diferença está na escolaridade, já que não inclui sujeitos com nivel superior.

\subsection{A VARIEDADE LUDOVICENSE}

Com a intenção de comparar padrões, as mesmas análises anteriores foram desenvolvidas com dados extraídos das entrevistas com os sujeitos nascidos e criados na capital maranhense. A seguir, os resultados são apresentados na mesma ordem dos anteriores.

\subsubsection{Distribuição Geral dos Dados}

A tabela a seguir apresenta a distribuição das ocorrências de indicativo e subjuntivo para cada um dos conjuntos de dados, na amostra ludovicense. 
Tabela 12: Distribuição geral dos dados - São Luís

\begin{tabular}{cccccc}
\hline $\begin{array}{c}\text { Orações } \\
\text { Subordinadas }\end{array}$ & $\begin{array}{c}\mathbf{N} \\
\text { Indicativo }\end{array}$ & $\%$ & $\begin{array}{c}\mathbf{N} / \% \\
\text { Subjuntivo }\end{array}$ & $\%$ & Total \\
\hline Adverbiais & 84 & 22,3 & 293 & 77,7 & 377 \\
Substantivas & 63 & 33,5 & 125 & 66,5 & 188 \\
Relativas & 99 & 39 & 155 & 61 & 254 \\
Total & & 39,1 & & 69,9 & 819 \\
\hline
\end{tabular}

A tabela 12 revela que o formas subjuntivas são mais frequentes que as indicativas nos três conjuntos de dados, na amostra ludovicense. Assim como se verificou para os dados paulistanos, também aqui é nas adverbiais são que o subjuntivo é mais frequente.

Há alguma diferença para os outros dois conjuntos de dados: o indicativo é um pouco mais frequente que o subjuntivo, na amostra paulistana, nas substantivas e nas relativas $152 \%$ e $53 \%$, respectivamente); já na ludovicense, o indicativo é menos frequente nessas duas estruturas (33\% e 39\%).

Por enquanto, contudo, essas diferenças percentuais servem apenas para mostras que os dados não se distribuem da mesma forma nas duas amostras. Mais tarde, conforme já se mencionou, quando da análise global dos dados, será possivel verificar se o grupo "conjunto de dados" e "cidade" são estatisticamente relevantes.

\subsubsection{Orações Adverbiais}

Para as orações adverbiais, as análises mostram que nenhum dos grupos de fatores sociais é estatisticamente significativo - assim como ocorreu para o mesmo conjunto de dados na amostra paulistana. A tabela a seguir apresenta pesos relativos obtidos de uma análise onelevel. 
Tabela 13: Orações adverbiais e Fatores Sociais - São Luís

\begin{tabular}{ccccc}
\hline $\begin{array}{c}\text { Grupo de } \\
\text { Fatores }\end{array}$ & Fatores & $\begin{array}{c}\text { Indicativo/ } \\
\text { Total }\end{array}$ & $\%$ & Peso Relativo \\
\hline \multirow{3}{*}{ Faixa Etária } & $18-35$ & $46 / 149$ & 30 & {$[.61]$} \\
& $36-59$ & $21 / 121$ & 17 & {$[.43]$} \\
& $60 \mathrm{ou}+$ & $17 / 107$ & 15 & {$[.40]$} \\
Sexo/Gênero & Masculino & $50 / 208$ & 24 & {$[.52]$} \\
& Feminino & $34 / 169$ & 20 & {$[.46]$} \\
Escolaridade & Colegial & $40 / 170$ & 23 & {$[.51]$} \\
Total de & Superior & $44 / 207$ & 21 & {$[.49]$} \\
ocorrências & & $84 / / 377$ & 22 & \\
\hline Input: 0.292 Significância: 0,001 &
\end{tabular}

Input: 0.292 Significância: 0,001

De forma semelhante ao que se verificou para a amostra paulistana, apesar de faixa etária não ter sido um grupo selecionado, há uma diferenciação entre mais jovens e as outras duas faixas. Assim, também da mesma forma como se procedeu anteriormente, a segunda e a terceira faixa foram amalgamadas e realizou-se uma nova análise dos dados. Aqui, diferentemente do que se observou para os dados paulistanos, tal amalgamação levou à seleção deste grupo como significativo.

Tabela 14: Orações adverbiais e a Faixa Etária - São Luís

\begin{tabular}{ccccc}
\hline $\begin{array}{c}\text { Grupo de } \\
\text { Fatores }\end{array}$ & Fatores & $\begin{array}{c}\text { Indicativo/ } \\
\text { Total }\end{array}$ & $\%$ & $\begin{array}{c}\text { Peso } \\
\text { Relativo }\end{array}$ \\
\hline Faixa & $18-35$ & $46 / 149$ & 30 & .59 \\
Etária & $36-59$ & $38 / 228$ & 16 & .44 \\
& $60 \mathrm{ou}+$ & & & Range: 15 \\
Total & & $84 / 377$ & & \\
\hline Input: 0.170 & Significância: 0.038 & &
\end{tabular}

Observa-se, desse modo, que é significativa a diferença entre os mais jovens, de um lado, e os falantes que têm 36 anos ou mais. Este é um padrão um tanto diferente daquele que se depreendeu da análise dos dados paulistanos, cuja amalmação das duas faixas etárias mais 
velhas não resultou na seleção do grupo como significativo. Aqui, portanto, temos que, mesmo nas subordinadas adverbiais, temos uma tendência de aumento do emprego do indicativo entre os mais jovens.

Figura 2: Tendências de Emprego do Indicativo e Faixa Etária - São Luís

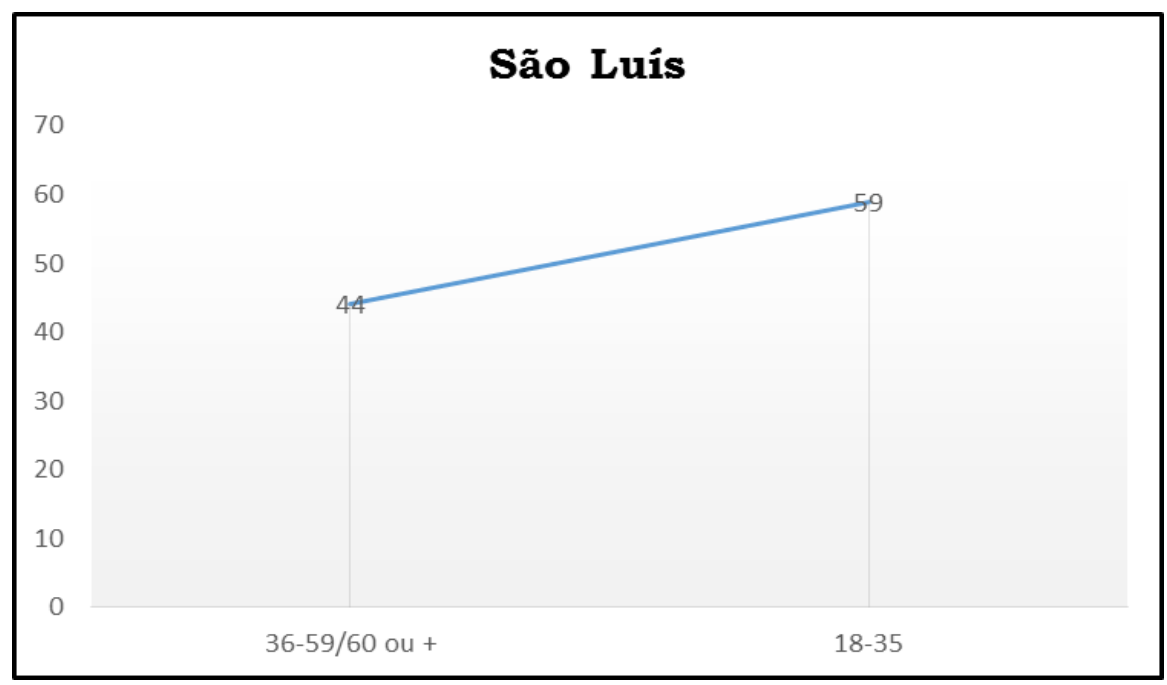

Tal resultado contraria, portanto, as expectativas iniciais -pelo menos no que concerne a subordinadas adverbiais. Conforme se mostrou na Tabela 5 , os pesos para as três faixas etárias nos dados paulistanos estavam muito mais próximos entre si (de modo que a amalgamação da segunda e da terceira não levou à seleção do grupo). Em outras palavras, temos indício de mudança nos usos ludovicenses em direção ao indicativo - mas não nos paulistanos.

Quanto a sexo/gênero e escolaridade, os resultados para a amostra ludovicense se assemelham àqueles verificados para a paulistana: não há diferença significativa entre homens e mulheres, nem entre mais e menos escolarizados.

Dentre os grupos de fatores linguísticos, foram selecionados, assim como na análise dos dados paulistanos, tempo verbal da oração subordinada e tipo de subordinador, conforme mostra a tabela 15 a seguir. 
Tabela 15: Orações adverbiais e Fatores Linguísticos - São Luís

\begin{tabular}{ccccc}
\hline $\begin{array}{c}\text { Grupo de } \\
\text { Fatores }\end{array}$ & Fatores & $\begin{array}{c}\text { Indicativo/ } \\
\text { Total }\end{array}$ & $\%$ & $\begin{array}{c}\text { Peso } \\
\text { Relativo }\end{array}$ \\
\hline $\begin{array}{c}\text { Tempo } \\
\text { Verbal da } \\
\begin{array}{c}\text { Oração } \\
\text { Subordinada }\end{array}\end{array}$ & Presente & $59 / 135$ & 43 & .86 \\
$\begin{array}{c}\text { Tipo de } \\
\text { Subordinador }\end{array}$ & $\begin{array}{c}\text { Outros } \\
\text { Subordinadores }\end{array}$ & $33 / 141$ & 23 & .25 \\
Ordem da & Prótase & $34 / 128$ & 26 & {$[.55]^{35}$} \\
Oração & Apódose & $50 / 247$ & 20 & {$[.47]$} \\
$\begin{array}{c}\text { Total de } \\
\text { ocorrências }\end{array}$ & & $84 / 376$ & & \\
\hline Input: 0.293 & Significância: 0.000 & & \\
\hline Range: 62 \\
\hline
\end{tabular}

Para tempo verbal da subordinada, mais uma vez é no presente que formas indicativas são favorecidas, enquanto se verifica forte desfavorecimento dessas formas no pretérito e no futuro.

Quanto ao tipo de subordinador, verifica-se que o maior peso não corresponde à maior porcentagem, o que indica interação entre os grupos dessa análise, provavelmente em razão da distribuição dos dados. Cruzando esse grupo com todos os outros que foram incluídos na análise, verifica-se que ele não é verdadeiramente independente do tempo verbal da oração subordinada:

35 Pesos relativos considerados nas rodadas one level. 
Tabela 16: Tipo de Subordinador VERSUS Tempo Verbal da Oração Subordinada - São Luís

\begin{tabular}{|c|c|c|c|c|c|c|}
\hline & & & \multicolumn{4}{|c|}{$\begin{array}{l}\text { Tempo Verbal da Oração } \\
\text { Subordinada }\end{array}$} \\
\hline & & & Presente & $\%$ & Pret./Fut. & $\%$ \\
\hline \multirow{6}{*}{$\begin{array}{c}\text { Tipo de } \\
\text { Subordinador }\end{array}$} & \multirow{3}{*}{$\mathrm{Se}$} & Indic. & 32 & 86 & 19 & 10 \\
\hline & & Subj. & 5 & 14 & 179 & 90 \\
\hline & & Total & 37 & & 198 & \\
\hline & \multirow{3}{*}{$\begin{array}{c}\text { Outros } \\
\text { subordina } \\
\text { dores }\end{array}$} & Indic. & 27 & 28 & 0 & - \\
\hline & & Subj. & 71 & 72 & 42 & 100 \\
\hline & & Total & 98 & & 42 & \\
\hline
\end{tabular}

De acordo com a tabela acima, não há ocorrências de "outros subordinadores" com indicativo nos tempos futuro ou pretérito. Além disso, é pequena a célula para subjuntivo no tempo presente (apenas 5 dados).

Dessa forma, realizou-se nova análise multivariada, excluindo-se o grupo tempo verbal e mantendo-se tipo de subordinador - que, neste caso, não foi selecionado como estatisticamente significativo:

Tabela 17: Orações adverbiais e o Tipo de Subordinador - São Luís

(Tempo verbal da subordinada excluido)

\begin{tabular}{ccccc}
\hline $\begin{array}{c}\text { Grupo de } \\
\text { Fatores }\end{array}$ & Fatores & $\begin{array}{c}\text { Indicativo/ } \\
\text { Total }\end{array}$ & $\%$ & $\begin{array}{c}\text { Peso } \\
\text { Relativo }\end{array}$ \\
\hline $\begin{array}{c}\text { Tipo de } \\
\text { subordinador }\end{array}$ & Outros & $33 / 141$ & 23 & {$[.51]$} \\
Total & Se & $51 / 235$ & 21 & {$[.49]$} \\
\hline
\end{tabular}

Input: $0.223 \quad$ Significância: 0.002

Dessa forma, esta é outra diferença que se verifica entre os dados paulistanos e ludovicenses, no que diz respeito às subordinadas adverbiais. Para aqueles, subordinadas com se favorecem bastante $\mathrm{o}$ 
uso de formas indicativas. Para estes, o grupo de fatores nem sequer é selecionado.

Quando se inclui o tempo verbal da oração subordinada e excluise tipo de subordinador, confirma-se sua relevância, conforme seria de esperar (pois tal grupo já havia sido anteriormente selecionado, a despeito da interação entre grupos de fatores).

Tabela 18: Orações Adverbiais e o Tempo Verbal da Oração Subordinada e retirada do Tipo de Subordinador - São Luís

\begin{tabular}{ccccc}
\hline $\begin{array}{c}\text { Grupo de } \\
\text { Fatores }\end{array}$ & Fatores & $\begin{array}{c}\text { Indicativo/ } \\
\text { Total }\end{array}$ & $\%$ & $\begin{array}{c}\text { Peso } \\
\text { Relativo }\end{array}$ \\
\hline $\begin{array}{c}\text { Tempo } \\
\text { verbal da } \\
\text { oração }\end{array}$ & Presente & $59 / 135$ & 43 & .78 \\
subordinada & Pretérito/Futuro & $25 / 241$ & 10 & .33 \\
& & & & $\begin{array}{c}\text { Range: } \\
\text { Total }\end{array}$ \\
\hline
\end{tabular}

Significância: 0.038 Input: 0.179

Finalmente, quanto à ordem das orações no periodo, da mesma forma que nos dados paulistanos, tal grupo não foi selecionado para os dados ludovicenses. Dessa forma, a maior diferença entre as duas comunidades está no fato de que, aqui, faixa etária é um grupo significativo (falantes mais jovens favorecem formas indicativas) e não há diferenciação quanto ao tipo de subordinador.

\subsubsection{Orações Subordinadas Substantivas}

Para o conjunto de dados em que se tem subordinação direta a um verbo foram controlados estatisticamente os grupos de fatores sociais sexo/gênero, faixa etária e escolaridade. Entre os linguísticos estão o verbo da oração principal, o tempo verbal da oração principal, o tempo verbal da oração subordinada e o grau de assertividade do periodo. A seguir, apresentam-se os resultados obtidos para as análises em que se consideraram os grupos de fatores sociais. 
Os grupos de fatores sociais controlados para as análises dos dados do contexto ludovicense são aqueles que estratificam a amostra: sexo/gênero, faixa etária e escolaridade.

Dentre os grupos analisados, "apenas" a faixa etária dos informantes foi selecionada como estatisticamente relevante para o fenômeno em análise, conforme se pode verificar na tabela 19 abaixo.

Tabela 19: Orações Substantivas e os Fatores Extralinguísticos

\begin{tabular}{ccccc}
\hline $\begin{array}{c}\text { Grupo de } \\
\text { Fatores }\end{array}$ & Fatores & $\begin{array}{c}\text { Indicativo/ } \\
\text { Total }\end{array}$ & \% & Peso Relativo \\
\hline & $18-35$ & $32 / 71$ & 45 & .63 \\
Faixa Etária & $36-59$ & $18 / 59$ & 30 & .45 \\
& $60 \mathrm{ou}+$ & $13 / 58$ & 22 & .38 \\
& & & & Range: 25 \\
Sexo/Gênero & Masculino & $37 / 95$ & 38 & {$[.56]^{36}$} \\
& Feminino & $26 / 93$ & 28 & {$[.43]$} \\
Escolaridade & Colegial & $33 / 87$ & 37 & {$[.54]$} \\
Total de & Superior & $30 / 101$ & 29 & {$[.45]$} \\
ocorrências & & $63 / 188$ & 33 & \\
\hline Input: 0.321 & Significância: 0.028 & &
\end{tabular}

De acordo com o que se pode verificar na tabela 19 acima, dos grupos de fatores extralinguísticos que estratificam a amostra, a faixa etária é aquele que mais se correlaciona com a seleção do modo indicativo, na expressão do modo subjuntivo, em São Luís.

Entre as três variantes dessa variável, são os sujeitos da primeira faixa os que mais favorecem a forma inovadora, com peso relativo .63, seguidos dos sujeitos da segunda faixa, com peso .45, e encerrando com os individuos mais idosos, com peso .38.

36 Pesos obtidos nas rodadas one-level. 
Com esses pesos relativos, e range 25, parece haver a indicação de um processo de mudança se iniciando na variedade do português ludovicense.

Os dados paulistanos também indicam o favorecimento desse grupo de fatores, no processo de variação, com a diferença que, na capital paulistana, esse processo encontra-se em estágio mais avançado, com uma frequência de $71 \%$, e uma diferença de mais ou menos $30 \%$ com relação aos indivíduos de segunda e terceira faixas etárias, enquanto que em São Luís, a diferença entre os mais jovens, que apresentam uma frequência de $45 \%$ de seleção da forma mais inovadora, e os sujeitos mais adultos gira em torno de $20 \%$.

Outro ponto importante em relação às variedades ludovicense e paulistana do português reside no fato de que os individuos mais jovens das duas cidades diferem em $30 \%$ nas frequências de uso do indicativo. Enquanto os jovens paulistanos atuam em $71 \%$ das ocorrências de indicativo, o que indica um avanço muito maior com direção à mudança, os ludovicenses atuam em $45 \%$ do mesmo processo. Esse resultado pode ser melhor visualizado nas figuras abaixo.

Figura 3: Frequência do indicativo - São Paulo e São Luís

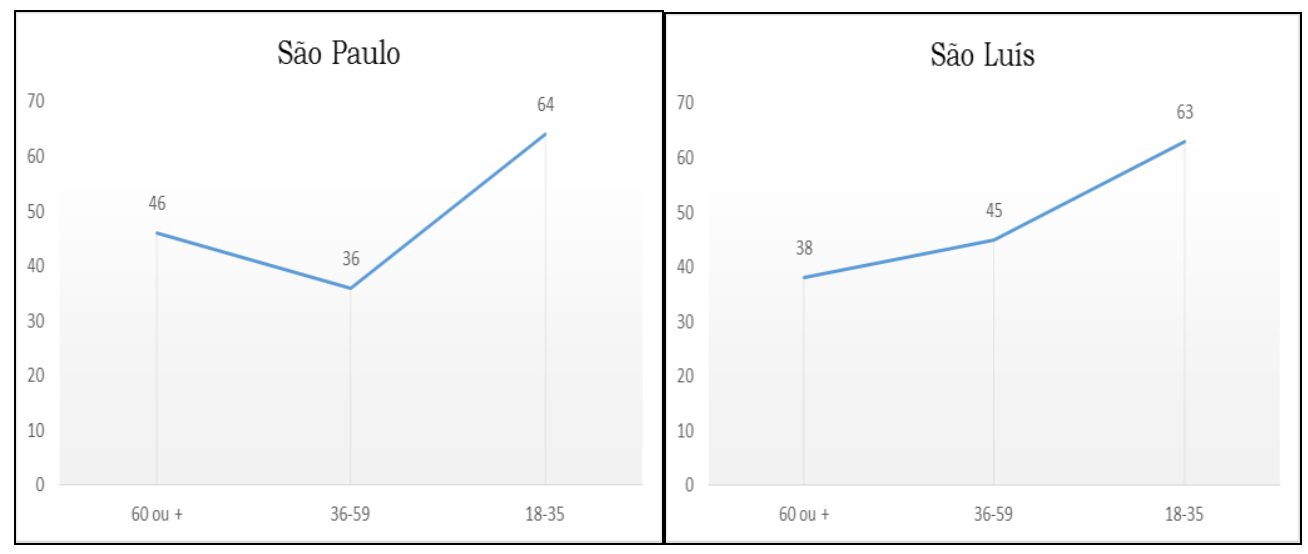

A comparação entre os gráficos permite que se observe que, embora as duas capitais caminhem para a mudança, parece que esse processo se dá de modos distintos nas duas cidades: enquanto em São 
Paulo a segunda faixa etária é que mais desfavorece a forma do indicativo, e apenas a primeira faixa etária distancia-se, favorecendo fortemente o indicativo, em São Luís, as três faixas etárias parecem se comportar distintamente quanto ao mesmo processo. Em São Paulo também parece confirmar-se uma mudança mais avançada do que em São Luís.

No caso do sexo/gênero, parece não haver diferenciações consideráveis entre homens e mulheres, no que diz respeito ao uso do indicativo, embora pareça que são os homens quem utilizam mais as formas do indicativo do que as mulheres. Esse resultado aproxima-se dos alcançados para São Paulo, onde também são os homens que parecem preferir a forma mais inovadora.

Também parece não haver correlação entre a escolaridade dos informantes e a expressão do subjuntivo em São Luís. Além de serem bastante infrequentes as taxas de realização de ocorrências do indicativo, os ludovicenses parecem se comportar de modo mais conservador nos casos de substantivas do que os paulistanos, cujas as taxas, inclusive para os sujeitos mais escolarizados, aproximam-se dos $50 \%$, enquanto que na capital maranhense essas frequências não chegam a $40 \%$.

Como se verificou, há uma correlação mais forte do indicativo com os sujeitos mais jovens, o que parece indicar uma mudança se iniciando no português ludovicense.

Dentre os grupos de fatores linguísticos controlados estatisticamente para o conjunto de dados de orações subordinadas substantivas, na variedade ludovicense do português também revelam correlações com a variável dependente. Desses grupos, aquele que mais se destaca nessa correlação, sendo selecionado como significante para o 
processo de variação, como se pode observar na tabela 20 a seguir, é o verbo da oração principal.

Tabela 20: Orações Substantivas e os Grupos de Fatores Linguísticos -

São Luís

\begin{tabular}{ccccc}
\hline $\begin{array}{c}\text { Grupo de } \\
\text { Fatores }\end{array}$ & Fatores & $\begin{array}{c}\text { Indicativo/ } \\
\text { Total }\end{array}$ & $\%$ & $\begin{array}{c}\text { Peso } \\
\text { Relativo }\end{array}$ \\
\hline $\begin{array}{c}\text { Verbo da } \\
\text { Oração }\end{array}$ & Cognitivos & $36 / 71$ & 50 & .68 \\
Principal & Volitivos/Factivos & $27 / 115$ & 23 & .38 \\
& & & & Range: \\
Tempo Verbal & Presente & $48 / 136$ & 36 & {$[.51]$} \\
da Oração & Pretérito/Futuro & $15 / 51$ & 28 & {$[.45]$} \\
Principal & & & & \\
& & & 34 & {$[.51]$} \\
Tempo Verbal & & 30 & {$[.46]$} \\
da Oração & Presente & $48 / 139$ & & \\
Subordinada & Pretérito/Futuro & $15 / 49$ & 35 & {$[.52]$} \\
Grau De & Afirmação/Afirmação & $23 / 64$ & 32 & {$[.48]$} \\
Assertividade & Negação em alguma & $40 / 124$ & & \\
do Periodo & posição do periodo & & & \\
Total & & $63 / 188$ & & \\
\hline
\end{tabular}

Input: 0.321 Significância: 0.028

Os resultados para o grupo de fatores verbo da oração principal confirmam a hipótese inicial de que verbos cognitivos são os que mais se correlacionam à forma mais inovadora. Verbos com essa carga semântica favorecem o indicativo com peso .68, e uma frequência de $50 \%$ dos contextos analisados, enquanto os verbos de volição e facção, aqui amalgamados em uma mesma variante, desfavorecem a forma mais inovadora, com peso .38.

Nesse ponto, parece que ludovicenses e paulistanos tendem a se assemelhar, já que também nessa variedade do português as taxas de uso do indicativo nos contextos de subordinadas substantivas são altas. 
Quanto aos grupos de fatores não selecionados como significativos, percebe-se que, embora haja uma diferenciação entre as formas, os índices altos de significância de 0.239, para o tempo verbal da oração principal, 0.458, para o tempo verbal da oração subordinada, e de 0.630 para o grau de assertividade do periodo, parecem indicar uma aleatoriedade na distribuição dos dados.

A seguir, apresentam-se os resultados para as análises multivariadas correspondentes às orações relativas.

\subsubsection{Orações Relativas}

Para os contextos que compõem o conjunto de dados em que se têm orações relativas, foram controlados, além dos grupos de fatores sociais que estratificam a amostra, e que também já foram analisados nas orações adverbiais e subordinadas substantivas, os grupos de fatores linguísticos tempo verbal da oração subordinada, grau de assertividade do periodo, bem como a distância entre o pronome relativo e a forma verbal em foco.

Dentre os grupos de fatores extralinguísticos analisados estatisticamente, foram considerados pelo GoldVarb como significativos "somente" a faixa etária dos informantes ludovicenses. A distribuição dos dados e os seus pesos relativos estão disponíveis na tabela 21 a seguir. 
Tabela 21: Orações Relativas e Grupos de Fatores Sociais - São Luís

\begin{tabular}{ccccc}
\hline $\begin{array}{c}\text { Grupo de } \\
\text { Fatores }\end{array}$ & Fatores & $\begin{array}{c}\text { Indicativo/ } \\
\text { Total }\end{array}$ & $\%$ & $\begin{array}{c}\text { Peso } \\
\text { Relativo }\end{array}$ \\
\hline Faixa Etária & $18-35$ & $28 / 79$ & 35 & .43 \\
& $36-59$ & $46 / 84$ & 54 & .63 \\
& $60 \mathrm{ou}+$ & $28 / 81$ & 34 & .42 \\
Sexo/Gênero & Masculino & $68 / 138$ & 44 & Range: 25 \\
& Feminino & $38 / 116$ & 32 & {$[.55]^{37}$} \\
Escolaridade & Colegial & $41 / 97$ & 42 & {$[.43]$} \\
Total de & Superior & $58 / 157$ & 36 & {$[.47]$} \\
ocorrências & & $99 / 254$ & 39 & \\
\hline Input: 0.321 & Significância: 0.028 & &
\end{tabular}

Tais resultados para faixa etária configuram-se de maneira bastante diferente em relação àqueles obtidos nas análises paulistanas. Os gráficos dispostos lado a lado abaixo ilustram essa diferença.

Figura 4: Frequência do Indicativo por faixa Etária - São Paulo e São Luís

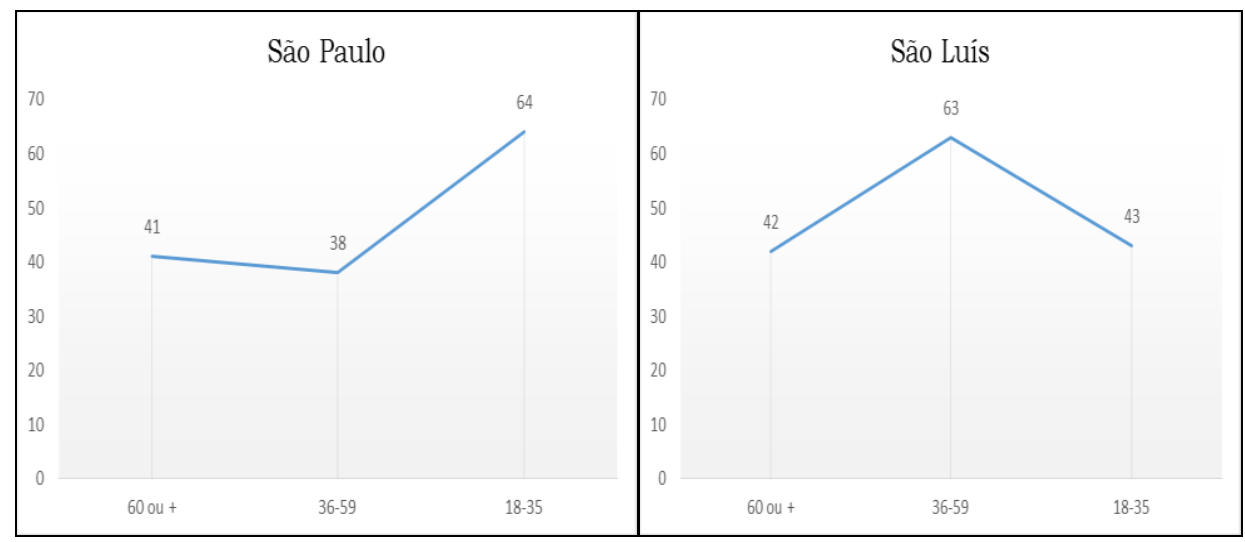

Em São Paulo, o padrão que se verifica para faixa etária nos dados de orações relativas se assemelha àquele das orações substantivas: mais velhos e falantes da faixa intermediária estão abaixo do ponto neutro (portanto, ambos desfavorecem formas indicativas), enquanto que os mais jovens favorecem essas formas. Conforme argumentou-se anteriormente, pode-se interpretar este padrão como

${ }^{37}$ Pesos obtidos nas rodadas one-level. 
um indício de mudança, na direção do indicativo - ainda que o desenho da curva se assemelhe um pouco àquele de variação estável, em que a segunda faixa etária exibe um peso um pouco mais baixo que a terceira. Assim como se observou para as substantivas, a questão toda está no fato de que a terceira faixa se assemelha mais à segunda, e não à primeira.

Para São Luís, entretanto, o padrão ilustrado acima é bem diferente daquele que se observou para as substantivas. Aqui, não temos indício de mudança, enquanto que para as substantivas, conforme vimos no item anterior, o aumento na tendência de emprego do indicativo é praticamente linear. Além disso, é difícil interpretar o fato de que os informantes da segunda faixa etária favoreçam o indicativo (em orações relativas) relativamente aos mais velhos e aos mais novos. Supondo-se que formas subjuntivas são prescritas em alguns casos, seria de esperar que o indicativo fosse evitado por estes falantes que, de acordo com a noção de "mercado linguístico" (BOURDIEU, 1991), sofreriam maior pressão social no sentido de empregar formas "mais adequadas e prestigiadas". Por outro lado, conforme vimos discutindo desde o capítulo 1, subjuntivo e indicativo não constituem "modos diferentes de dizer a mesma coisa", de modo que noções de prestígio não se colocam, no presente caso, da mesma forma que em casos "canônicos" de variação. Dessa forma, o fato mais interessante a ser destacado é o de que, em São Luís, as tendências de uso são bastante diferentes quando se trata de orações substantivas e de orações relativas - mudança na direção do indicativo no primeiro, estabilidade no segundo.

Há outra diferença entre São Luís e São Paulo no que toca a fatores sociais: sexo/gênero foi selecionado na análise das relativas na amostra paulistana (mulheres desfavorecem formas indicativas, relativamente aos homens), mas não na ludovicense. Escolaridade, por outro lado, permanece como um grupo de fatores de natureza social não 
selecionado - em todos os conjuntos de dados, nas amostras das duas cidades.

Observa-se também outra diferença entre os dados paulistanos e ludovicenses, quando se passa para os grupos de fatores linguísticos. Aqui, há uma pequena diferenciação no emprego de formas indicativas e subjuntivas, em correlação à distância entre o verbo da subordinada e o relativo que - um grupo de fatores que não fora selecionado na análise dos dados paulistanos. Aqui, o indicativo é um pouco favorecido quando o verbo está mais próximo do relativo que. Este resultado não se equipara ao de outros estudos (ALVES, 2009; GRIMM, 2012, por exemplo), em que o relativo tende a favorecer o emprego do subjuntivo.

Tabela 22: Orações Relativas e os Grupos de Fatores Linguísticos - São Luís

\begin{tabular}{|c|c|c|c|c|}
\hline $\begin{array}{c}\text { Grupo de } \\
\text { Fatores }\end{array}$ & Fatores & $\begin{array}{c}\text { Indicativo/ } \\
\text { Total }\end{array}$ & $\%$ & $\begin{array}{c}\text { Peso } \\
\text { Relativo }\end{array}$ \\
\hline $\begin{array}{c}\text { Tempo Verbal da } \\
\text { Oração } \\
\text { Subordinada }\end{array}$ & $\begin{array}{c}\text { Presente } \\
\text { Pretérito/Futuro }\end{array}$ & $\begin{array}{l}72 / 160 \\
27 / 94\end{array}$ & $\begin{array}{l}45 \\
28\end{array}$ & $\begin{array}{c}.55 \\
.40 \\
\text { Range: } 10\end{array}$ \\
\hline $\begin{array}{c}\text { Distância entre } \\
\text { o pronome } \\
\text { relativo e a } \\
\text { forma verbal em } \\
\text { foco }\end{array}$ & $\begin{array}{l}\text { Forma verbal adjacente } \\
\text { ao pronome relativo } \\
\text { Presença de um ou mais } \\
\text { elementos }\end{array}$ & $\begin{array}{l}62 / 153 \\
38 / 116\end{array}$ & $\begin{array}{l}40 \\
36\end{array}$ & $\begin{array}{c}.52 \\
.46 \\
\text { Range: } 06\end{array}$ \\
\hline $\begin{array}{c}\text { Grau de } \\
\text { assertividade da } \\
\text { Oração } \\
\text { Total de } \\
\text { ocorrências }\end{array}$ & $\begin{array}{c}\text { Afirmação/afirmação } \\
\text { Negação em alguma } \\
\text { posição }\end{array}$ & $\begin{array}{l}74 / 185 \\
25 / 68 \\
99 / 254\end{array}$ & $\begin{array}{l}40 \\
36\end{array}$ & $\begin{array}{l}{[.5]^{38}} \\
{[.47]}\end{array}$ \\
\hline
\end{tabular}

Observa-se ainda outra diferença entre esses resultados e aqueles obtidos na análise da amostra paulistana: ainda que em ambas o indicativo seja favorecido quando o verbo está no tempo presente, tal favorecimento é bem maior nos dados paulistanos (peso .60, range $33-$ Cf. item 4.1.3). Na tabela acima, o índice para verbos no presente é .55

38 Pesos obtidos nas rodadas one-level. 
e o range para este grupo é bem menor (10) - de modo que a correlação é menor forte.

Finalmente, a presença de elementos negativos no período não se correlaciona ao emprego das formas indicativas ou subjuntivas assim como se havia observado para os dados paulistanos.

\subsection{ANÁLISE GLOBAL}

As análises acima enfocaram as amostras separadamente. No item 5.1, reportaram-se os resultados para os dados paulistanos; no item 5.2, para os ludovicenses. Em cada um dos casos, analisaram-se, também separadamente, os diferentes contextos de subordinação: adverbiais, substantivas e relativas. Há muitas semelhanças na variação/alternância entre formas indicativas e subjuntivas em São Paulo e São Luís, mas há também algumas diferenças importantes, que podem ser assim resumidas:

- orações adverbiais:

- faixa etária não é um grupo selecionado para os dados de São Paulo, mas é para os de São Luís (com indicativo de mudança na direção do indicativo);

- tipo de subordinador não é selecionado para São Luís, mas o é para São Paulo (o indicativo é favorecido nas subordinadas com se);

- orações substantivas:

- faixa etária é um grupo selecionado na análise de ambas as amostras, mas o padrão que indica mudança (em tempo aparente) na direção do indicativo é linear para São Luís;

- tempo verbal da oração principal não é selecionado para São Luís, mas o é para São Paulo (o presente favorece o indicativo); 
- orações relativas:

- faixa etária é um grupo selecionado para ambas as amostras, mas o padrão é indicativo de aumento do emprego do indicativo em São Paulo, mas não em São Luís;

- sexo/gênero é selecionado para a amostra paulistana (mulheres tendem a evitar o indicativo), mas não em São Luís.

No geral, esses resultados não confirmam as avaliações "populares", discutidas no capítulo 1, de acordo com as quais, supostamente, "São Paulo não empregaria subjuntivo", enquanto que São Luís, em razão de seu caráter conservador do "bom português", evitaria o emprego do indicativo nos casos em que o subjuntivo é prescrito, recomendado ou possivel. O exame dos resultados nos itens anteriores do presente capítulo, juntamente com o resumo (acima) das diferenças entre os resultados das análises para os dados das duas capitais indicam padrões bem mais complexos do que o tipo de visão que se expressa em proposições do tipo: "num lugar, não se emprega tal forma; em outro lugar, não se emprega outra”.

Veja-se, por exemplo, que nas orações adverbiais, não há indício de mudança na direção do indicativo em São Paulo - diferentemente do que se observa em São Luís, cujos dados apontam para um aumento do emprego do indicativo entre os mais jovens. Considerando-se que também há aumento na tendência de emprego do indicativo entre ludovicenses mais jovens também para as orações substantivas, podese dizer que, no geral, o indicativo está se implementando como forma alternativa (nos contextos em que o subjuntivo é possivel) nas duas capitais, mas talvez mais rapidamente em São Luís do que em São Paulo - considerando-se, reitere-se, os resultados para adverbiais e substantivas sobretudo.

Entretanto, convém verificar se as diferenças entre as duas cidades são estatisticamente significativas, numa análise em que todos 
os dados são utilizados em conjunto. Neste caso, não se incluem os grupos de fatores linguísticos - já que eles são diferentes para cada conjunto de dados - e, por outro lado, não interessam os grupos de fatores sociais, já que se trata de comunidades diferentes e os resultados para eles, de acordo com o que se reporta nos itens 4.1 e 4.2 acima, são diferentes para cada conjunto de dados. Dessa forma, a tabela abaixo oferece os resultados para "conjunto de dados" (que, na análise global, se configura como uma variável independente) e "cidade".

Tabela 23: Análise Global com o Conjunto de Dados e Cidade

\begin{tabular}{ccccc}
\hline $\begin{array}{c}\text { Grupo de } \\
\text { Fatores }\end{array}$ & Fatores & $\begin{array}{c}\text { Indicativo/ } \\
\text { Total }\end{array}$ & \% & Peso Relativo \\
\hline Cidade & São Paulo & $395 / 1009$ & 39,1 & .56 \\
& São Luís & $246 / 819$ & 30 & .42 \\
& & & Range: 13 \\
Conjunto de & Relativas & $226 / 496$ & 45,6 & .58 \\
Dados & Substantivas & $159 / 369$ & 43,1 & .52 \\
& Adverbiais & $256 / 963$ & 26,6 & .45 \\
Total de & & & & Range: 13 \\
ocorrências & & $641 / 1828$ & 35,1 & \\
\hline Input: 0.322 & & & &
\end{tabular}

No conjunto total de dados, portanto, vemos que o indicativo tende a ser mais empregado nas relativas. Esses resultados não devem ser interpretados em detrimento daqueles que se apresentaram anteriormente. Isso quer dizer que as análises anteriores são mais explanatórias, uma vez que há padrões diferentes para cada contexto de subordinação. Entretanto, os resultados da tabela acima são interessantes na medida em que, num conjunto maior de dados (1828, no total), pode-se dizer que o indicativo não é a forma favorecida nas orações adverbiais - relativamente a substantivas e relativas. Considerando-se a proposta encaminhada no capitulo 1 - o subjuntivo é composicional nas adverbiais e, nelas, formas indicativas e subjuntivas funcionam mais propriamente como variantes de uma variável - pode-se dizer que o subjuntivo permanece como forma 
produtiva neste contexto. Além disso, observe-se que, no conjunto global, formas indicativas representam $35 \%$ dos dados.

No que concerne à diferença entre as cidades, a tabela mostra que ela é significativa, e que o indicativo é favorecido na fala paulistana - mas com um peso relativo pouco acima do ponto neutro. Considerando-se todos os resultados reportados anteriormente, pode-se dizer que tal diferença é pequena - considerando-se as avaliações de que "São Paulo não emprega subjuntivo" e "São Luís conserva o bom português".

Essas diferenças permanecem, contudo, quando os conjuntos de dados são analisados separadamente, mantendo-se "cidade" como grupo de fatores.

Tabela 24: Conjunto de Dados e Cidade

\begin{tabular}{|c|c|c|c|c|}
\hline Grupo de Fatores & Fatores & $\begin{array}{c}\text { Indicativo/ } \\
\text { Total }\end{array}$ & $\%$ & $\begin{array}{c}\text { Peso } \\
\text { Relativo }\end{array}$ \\
\hline Adverbiais & $\begin{array}{l}\text { São Paulo } \\
\text { São Luís }\end{array}$ & $\begin{array}{c}180 / 594 \\
86 / 385\end{array}$ & $\begin{array}{l}30 \\
22\end{array}$ & $\begin{array}{l}.54 \\
.43\end{array}$ \\
\hline & & & & Range: 11 \\
\hline Substantivas & $\begin{array}{l}\text { São Paulo } \\
\text { São Luís }\end{array}$ & $\begin{array}{c}100 / 184 \\
64 / 187\end{array}$ & $\begin{array}{l}54 \\
34\end{array}$ & $\begin{array}{c}.60 \\
.39 \\
\text { Range: } 21\end{array}$ \\
\hline Relativas & $\begin{array}{c}\text { São Paulo } \\
\text { São Luís }\end{array}$ & $\begin{array}{l}125 / 237 \\
102 / 245\end{array}$ & $\begin{array}{l}52 \\
41\end{array}$ & $\begin{array}{c}.55 \\
.45 \\
\text { Range: } 10\end{array}$ \\
\hline Total de ocorrências & & $266 / 979$ & 27 & \\
\hline
\end{tabular}

A tabela acima mostra que a diferença é maior para as subordinadas substantivas (range 21); os pesos relativos para São Paulo e São Luís estão mais próximos entre si no caso das adverbiais e das relativas. Esses resultados ficam mais claros no histograma abaixo 
Figura 5: Tendências de emprego do Indicativo em São Paulo e São Luís

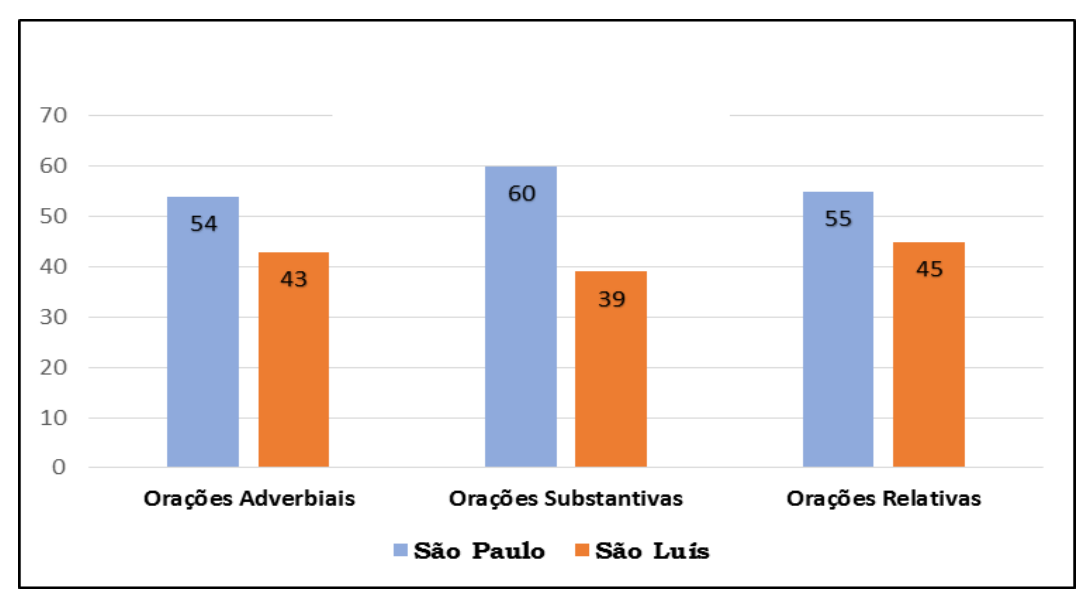

No seu conjunto, portanto, as análises reportadas neste capítulo permitem concluir que: (i) os padrões de alternância de formas indicativas e subjuntivas são diferentes nas duas cidades; (ii) essas diferenças são estatisticamente significativas e (iii) são maiores quando se trata de orações substantivas e, finalmente (iv) ainda que o indicativo tenda a ser relativamente mais empregado em São Paulo, há indícios de mudança na direção do indicativo em São Luís (nas subordinadas adverbiais e substantivas - conforme vimos nos itens 5.2 .1 e 5.2 .2 mais acima). 


\section{CONCLUSÕES}

Este estudo focalizou a alternância de formas indicativas e subjuntivas em contextos nos quais ambas são possíveis: orações subordinadas adverbiais (é como se pra gente era/fosse normal), substantivas (eu sempre achava que ele ia/fosse dar bronca na gente) e relativas (não tem gente que anda/ande de Porsche na Freguesia do Ó). No capítulo 1, propôs-se que formas indicativas e subjuntivas funcionam mais propriamente como formas alternantes (já que, qualquer que seja a forma verbal, pode-se dizer que se está expressando subjuntividade). Ainda assim, os três conjuntos de dados foram examinados à maneira variacionista, em análises que incluíram grupos de fatores sociais (cidade de origem, sexo/gênero, escolaridade e faixa etária) e linguísticas (tempo verbal, ordem de orações do período, presença de elementos de negação, entre outros). Os dados paulistanos e ludovicenses foram analisados separadamente, para cada conjunto de dados e, ao final, foram analisados também globalmente, no sentido de testar estatisticamente as diferenças entre as duas cidades. Todos os testes foram desenvolvidos com o pacote GoldVarb X (SANKOFF; TAGLIAMONTE; SMITH, 2005).

Para as orações adverbiais, o tempo verbal da subordinada mostrou-se como uma variável importante tanto para os dados ludovicenses quanto para os paulistanos (o presente favorece o emprego do indicativo); já o tipo de subordinador mostrou-se relevante apenas para os paulistanos (que tendem a empregar indicativo em orações condicionais com se, mas tendem a favorecer o subjuntivo nos demais casos). Por outro lado, verificou-se um padrão indicativo de mudança (em tempo aparente), na direção do indicativo - em São Luís, mas não em São Paulo.

Para as orações substantivas, o verbo da oração principal foi selecionado para as duas amostras: verbos cognitivos favorecem formas 
do indicativo, de acordo com a hipótese inicial e com resultados de outros trabalhos (CARVALHO, 2007; FAGUNDES, 2007; PIMPÃO, 2012). Entre paulistanos, também se verificou como relevante o tempo verbal da oração principal - o presente favorece o indicativo, enquanto que passado e futuro favorecem o subjuntivo. Mais uma vez, o grupo faixa etária ofereceu resultados interessantes: há indicativo de mudança na direção do indicativo tanto na fala ludovicense quanto na paulistana, mas, no primeiro caso, o padrão curvilíneo é linear (o que indica mais prototipicamente um progressivo aumento na tendência do emprego de formas indicativas).

Quando se trata de orações relativas, o tempo verbal da oração subordinada é significativos para os dados das duas capitais, a exemplo do que se verificou em vários outros trabalhos, que enfocam diferentes variedades do português e outras línguas (Carvalho, 2007; Pimpão, 1999 ;2012; Poplack, 1994; Wherritt, 1977) - o presente favorece o indicativo. A distância entre o pronome que e o verbo da subordinada também tem correlação com os dados, mas não muito intensa e apenas para os dados ludovicenses. Também neste contexto, faixa etária mostrou resultados interessantes, com indicativo de mudança na amostra paulistana, mas não na ludovicense. A variável sexo/gênero mostrou-se estatisticamente relevante para a variedade paulistana: as mulheres tendem a evitar o indicativo nas relativas, relativamente aos homens.

Quando os dados são analisados globalmente, verifica-se que as diferenças nas distribuições das ocorrências de formas indicativas e subjuntivas entre São Paulo e São Luís são estatisticamente significativas para os três contextos de subordinação, mas a diferença é maior no caso das orações substantivas. Em outras palavras, o indicativo tende a ser relativamente pouco mais usado em São Paulo do que em São Luís - nas orações adverbiais e relativas - mas bastante mais nas substantivas. Tal resultado, contudo, não cancela o que se 
verificou nas análises dos conjuntos de dados em separado: o emprego do indicativo vem crescendo em São Luís, particularmente nas orações adverbiais e substantivas.

Em suma, este trabalho pode-se verificar que ludovicenses e paulistanos mais se aproximam do que se distanciam - considerando-se as expectativas iniciais, baseadas em avaliações "populares" sobre os emprego de formas subjuntivas e indicativas nas duas cidades. Nesse sentido, o trabalho mostra que padrões de encaixamento linguístico e social de formas alternantes é bastante mais complexo do que se pode pensar: certamente, a realidade dos dados não confirma visões de "distribuição complementar", do tipo: tais falantes usam tais formas; outros falantes usam outras formas.

Com a análise comparativa de dados coletados em duas comunidades urbanas tão distintas, espera-se ter contribuído para o desenho de uma mapa dos padrões de uso de formas subjuntivas e de sua progressiva substituição por formas indicativas (sobretudo em São Luís - em virtude dos padrões depreendidos em tempo aparente). Além disso, este trabalho iniciou a discussão de uma proposta: o modo subjuntivo é expresso como uma categoria composicional, sobretudo no caso de orações adverbiais. 


\section{REFERÊNCIAS}

ABREU, Sylvio Fróes. Na terra das palmeiras. Rio de Janeiro: Oficina Industrial Gráphica, 1931.

ALI, M. Said. Gramática Histórica da Lingua Portuguesa. $6^{\mathrm{a}}$ edição, São Paulo: Melhoramentos, 1966.

ALMEIDA, Erica de Sousa. Variação de uso do subjuntivo em estruturas subordinadas: do século XIII ao XX. 2010. 294f. Tese (Doutorado em Letras Vernáculas) - Programa de Pós-graduação em Letras Vernáculas, Universidade Federal do Rio de Janeiro, Rio de Janeiro, 2010.

ALVES, Cibelle Corrêa Béliche. O uso do tu e do você no português falado no Maranhão. 2010. 143f. Dissertação (Mestrado em Linguística) - Programa de Pós-Graduação em Linguística, Universidade Federal do Ceará, Fortaleza, 2010.

ALVES, Rosana F. A expressão de modalidades tipicas do subjuntivo em duas sincronias do português: século XVI e contemporaneidade. 2009. 197f. Tese (Doutorado em Linguística) - Instituto de Estudos da Linguagem, Universidade Estadual de Campinas, Campinas, 2009.

ALVES NETA, A. O uso de formas do indicativo por formas do subjuntivo no português brasileiro. 2000. 114f. Dissertação (Mestrado em Letras: Linguística) - Faculdade de Letras, Universidade Federal de Minas Gerais, Belo Horizonte, 2000.

AZEVEDO, Ramiro Corrêa. O falar São-Luisense. Construtora. São Paulo, n. 3, p. 269-278, 1973.

Áreas linguísticas do Maranhão. Littera. Rio de Janeiro, p. 103-112. jan/jun., 1976.

; VIEIRA, Maria do Socorro Monteiro, MELO, Elenice Bezerra. Antropolinguística: Raposa. São Luís: SIOGE, 1980.

BARBOSA, Astrid F. Alternância de formas indicativas e subjuntivas na fala de Vitória (ES). 2011. 146f. Dissertacao (Mestrado em Linguistica) - Universidade Federal do Espirito Santo, Vitoria, 2011.

BARRA ROCHA, Maria. M. O modo subjuntivo em português: um estudo contrastivo com o italiano. 1992. 189f. Dissertação (Mestrado em Letras) Faculdade de Letras, Universidade Federal de Minas Gerais, Belo Horizonte, 1992.

BECHARA, Evanildo. Moderna gramática portuguesa. Rio de Janeiro: Lucerna, 37 ed., 2005. 
BENTIVOGLIO, P. A variação nos estudos sintáticos. Estudos Lingüísticos, n. 15, p. 7-29, 1987.

BIANCHET, Sandra Maria G. B. Indicativo e/ou subjuntivo em orações completivas objetivas diretas do português: uma volta ao latim. Belo Horizonte: UFMG, 1996.

BLATT, Franz. Precis de Syntaxe Latine. Lyon: IAC, 1952.

Bourdieu, P. Language and Simbolic Power. Cambridge: Polit Press, 1991.

BOTELHO PEREIRA, Maria Ângela. Aspectos da oposição modal indicativo/subjuntivo no Português Contemporâneo. Rio de Janeiro: UFRJ, 1974, 265p. Dissertação (Mestrado em Linguística), Curso de Pós-Graduação em Linguística, Universidade Federal do Rio de Janeiro.

BORTONI-RICARDO, Stella Maris. Educação em lingua materna: a sociolingüística na sala de aula. São Paulo: Parábola Editorial, 2004.

CAMARA JR., Joaquim Mattoso. Estrutura da Lingua Portuguesa. 42. ed. Petrópolis: Vozes, 2009.

CARVALHO, Hebe M. de. A alternância indicativo/subjuntivo nas orações substantivas em função dos tempos verbais presente e imperfeito na lingua falada do Cariri. 2007. 158f. Tese (Doutorado em Linguística) - Departamento de Letras Vernáculas, Universidade Federal do Ceará, Fortaleza, 2007.

CASTILHO, Ataliba Teixeira de; PRETI, Dino (Orgs.). A linguagem falada culta na cidade de São Paulo: TAQ/Fapesp. Vol. I: elocuções formais. São Paulo: T.A. Queiroz, 1986.

Projeto para a História do Português Paulista. 2007. Projeto temático de Equipe 06/5594-0 apresentado a FAPESP. Universidade de São Paulo, São Paulo, 2007.

CHAMBERS, J. K. "Patterns of Variation incluing Change". In.: Chambers, J. K.,Trudgill, P. \& Schilling- Estes, N. The Handbook of Language Variation and Change. Malden / Oxford / Carlton; Blackweel, 2003.

CUNHA, Celso \& CINTRA, Luís Felipe Lindley. Nova Gramática do português contemporâneo. Rio de Janeiro: Nova Fronteira, 1985.

CURVELO, Heloisa Reis. Topônimos maranhenses: testemunhas de um passado ainda recente. 2009. 248 f. Dissertação (Mestrado em Linguística) Programa de Pós-graduação em Linguística, Universidade Federal do Ceará, Fortaleza, 2009.

FAGUNDES, Edson Domingos. As ocorrências do modo subjuntivo nas entrevistas do VARSUL no estado do Paraná e as possibilidades de variação com o modo indicativo. 2007. 189 f. Tese (Doutorado em Letras) - Programa de Pós-graduação em Letras, Universidade Federal do Paraná, Curitiba, 2007.

FREIRE, Ricardo. Subjuntivo à paulista. Revista Época, São Paulo: Globo, edição 400 de 16 jan., ano 8. São Paulo: 2006, p. 98. 
GATTI, Iris. O emprego do modo subjuntivo no alemão e no português do Brasil: primeiro panorama contrastivo e ênfase no emprego nas orações subordinadas substantivas. 2004. 257 f. Tese (Doutorado em Letras). Programa de PósGraduação em Letras Modernas, Universidade de São Paulo, São Paulo.

GIVON, Talmy. Syntax: a functional-typological introduction. Amsterdam/Philadelphia: John Benjamins, 1984.

GOMES DA SILVA. Fernando. Alagoanos em São Paulo e a Concordância Nominal de Número. 2014, 103f. Dissertação (Mestrado em Semiótica e Linguística Geral) - Programa de Pós-graduação em Semiótica e Linguística Geral - Faculdade de Filosofia, Letras e Ciências Humanas, Universidade de São Paulo, São Paulo, 2014.

GONÇALVES, Sebastião Carlos Leite. Banco de dados Iboruna: amostras eletrônicas do português falado no interior paulista., s/d. Disponível em: <URL http:://www.alip.ibilce.unesp.br/iboruna>. Acessado em: 15 out. 2014.

GRIMM, Rick. The variable use of the subjunctive mood in spoken Ontarian French. In: MEETING OF THE LINGUISTICS SOCIETY OF AMERICA, 86th., 2012, Portland. Meeting Handbook... Disponivel em: <http://www.lsadc.org/info/documents/2012/annualmeeting/handbook.pdf >. Acesso em: 07 ago. 2014.

GUY, Gregory; ZILLES, Ana. Sociolinguística quantitativa: instrumental de análise. São Paulo: Parábola Editorial, 2007.

HIRATA, Flávia B. de M. A ordem nas construções condicionais do português escrito do Brasil. Estudos Linguísticos. XXIX GEL/UNESP, 1999.

HONÓRIO DO COUTO, Hildo. O Que é Português Brasileiro. São Paulo: Brasiliense, 1986.

KATO, Mary A; Tarallo, Fernando et alii. Preenchedores sintáticos nas fronteiras de constituintes. In: CASTILHO, Ataliba T. (Org.). Gramática do Português Falado. Campinas: Editora da UNICAMP, v.3, 1993.

LABOV, W. Padrões sociolinguísticos. Tradução de Marcos Bagno, Maria Marta Pereira Scherre, Caroline Rodrigues Cardoso. São Paulo: Parábola Editorial, 2008 [1972].

. "Where does the sociolinguistic variable stop? A response to Beatriz Lavandera". Working Papers in Sociolinguistics, 1978.

. The three dialects of English. In: ECKERT, Penelope. (ed.). New Ways of Analyzing Sound Change. New York: Academic Press, 1991. pp. 1-44.

Principles of Linguistic Change: external factors. Oxford \& Cambridge: Blackwell, 2001.

The social stratication of English in New York City. São Paulo: Cambridge University Press, 2006 [1966]. 
Principles of Linguistic Change: Cultural e Cognitive Factors, vol. III. Oxford: Wiley - Blackwell, 2010.

MEIRA, Vivian. O uso do modo subjuntivo em orações relativas e completivas no português afro-brasileiro. 2006. 317f. Dissertação (Mestrado em Letras e Linguistica) - Instituto de Letras, Universidade Federal da Bahia, Salvador, 2006.

MENDES, Ronald B.; OUSHIRO, Livia. O paulistano no mapa sociolinguístico brasileiro. Alfa, São Paulo, 56 (3): 973-1001, 2012.

MENDES, Ronald B. Documentação do Projeto SP2010 - Construção de uma amostra da fala paulistana.", 2013. Disponível em: <http://projetosp2010.fflch.usp.br>. Acessado em: 15 out. de 2014.

MENDES DE ALMEIDA, N. Gramática metódica da língua portuguesa. 45. ed. Sao Paulo: Saraiva, 2005.

MILROY, Leslie. Social networks. In: Chambers, J.K., P. Trudgill \& N. Schilling-Estes (eds.). The Handbook of Language Variation and Change. Oxford: Blackwell, 2004.

MIRA MATEUS, Maria H. Gramática da Lingua Portuguesa. 5. ed. Lisboa: Caminho, 2003.

MOLLICA, Maria C. Fundamentação teórica: conceituação e delimitação. In: MOLLICA, Maria C.; BRAGA, Maria L. (orgs.). Introdução à sociolinguística: o tratamento da variação. São Paulo: Contexto, 2004. pp. 9-14.

- Relevância das variáveis não linguísticas. In: MOLLICA, Maria C.; BRAGA, Maria L. (orgs.). Introdução à sociolinguistica: o tratamento da variação. São Paulo: Contexto, 2004. pp. 27-31.

MOTA, Leonardo. Sertão Alegre. 4. ed. Rio de Janiero: Cátedra,1976 [1928].

NARO, Anthony. J. Modelos quantitativos e tratamento estatístico. In: MOLLICA, M. (Org.). Cadernos didáticos UFRJ: Introdução à sociolingüística variacionista. Rio de Janeiro: UFRJ, 1992, p. 17-25.

NASCIMENTO, Ivanete Belém do. O uso variável do pronome de segunda pessoa você(s) e cê(s) na cidade de São Paulo. 2011, 217f. Dissertação (Mestrado em Semiótica e Linguística Geral) - Programa de Pós-graduação em Semiótica e Linguística Geral - Faculdade de Filosofia, Letras e Ciências Humanas, Universidade de São Paulo, São Paulo, 2011.

NEVES, Maria Helena de M. Gramática de usos do português. São Paulo: Editora da UNESP, 2000.

OLIVEIRA, Josane M. de. O futuro da lingua portuguesa ontem e hoje: variação e mudança. 2006. 254f. Tese (Doutorado em Língua Portuguesa) - Faculdade de Letras, Universidade Federal do Rio de Janeiro, Rio de Janeiro, 2006. 
OLIVEIRA, Maria do C. O uso do modo verbal em estruturas de complementação no português do Brasil. 2007. 155f. Dissertação (Mestrado em Linguística) - Instituto de Letras, Universidade de Brasília, Brasília, 2007.

OUSHIRO, Livia. Uma análise variacionista para as interogativas -Q. 2011. 160f. Dissertação (Mestrado em Semiótica e Linguística Geral) - Programa de Pós-graduação em Semiótica e Linguística Geral - Faculdade de Filosofia, Letras e Ciências Humanas, Universidade de São Paulo, São Paulo, 2011.

Identidade na pluralidade: produção e percepção linguística na cidade de São Paulo. Projeto de doutorado (FAPESP) apresentado ao Programa de Pós-Graduação em Semiótica e Linguística Geral do DL-FFLCH-USP, 2011b. Ms.

PAIVA, Maria da Conceição de. Sexo. In: MOLLICA, M. (Org.). Cadernos didáticos UFRJ: Introdução à sociolingüistica variacionista. Rio de Janeiro: UFRJ, 1992, p. 69-73.

. A variável sexo/gênero. MOLLICA, Maria C.; BRAGA, Maria L. (orgs.). Introdução à sociolinguística: o tratamento da variação. São Paulo: Contexto, 2004. pp. 36-42.

PIMPÃO, Tatiana. S. Variação no presente do indicativo do modo subjuntivo: uma abordagem discursivo-pragmática. Florianópolis, 1999. $128 \mathrm{f}$. Dissertação (Mestrado em Linguística) - Universidade Federal de Santa Catarina.

Uso variável do presente no modo subjuntivo: uma análise de amostras de fala e escrita das cidades de Florianópolis e Lages nos séculos XIX e XX. Florianópolis, 2012. 350 f. Tese (Doutorado em Linguística) - Universidade Federal de Santa Catarina.

POPLACK, Shana. Prescription, intuition, et usage: le subjonctif francais el la variabilite inherente. Language et société, n. 54, p. 5-33, dec. 1990.

A dinâmica sociolinguística da aparente convergência. In: D.E.L.T.A. v. 10, número especial. pp. 141-172, 1994.

PRAZERES MARANHÃO, Frei Francisco de Nossa Senhora dos. Porandunba Maranhense. Revista de Geografia e História, São Luís, n.1, dez. 1946. Separata.

PRETI, Dino; URBANO, Hudinilson. (Eds.). A linguagem falada culta na cidade de São Paulo: materiais para seu estudo, vol. III - Entrevistas. São Paulo: T.A. Queiroz/FAPESP, 1988.

A linguagem falada culta na cidade de São Paulo: materiais para seu estudo, vol. IV - ESTUDOS. São Paulo: T.A. Queiroz/FAPESP, 1990.

RAMOS, Conceição de Maria de Araújo. O português falado em São Luís: os pronomes pessoais na posição de sujeito, 1996. (mimeo). 
- (Coord.). Projeto Atlas Linguístico do Maranhão. São Luís: Universidade Federal do Maranhão. (Departamento de Letras). 88 p. Projeto em andamento, 2000.

ROCHA, Maria de Fátima Sopas. A festa do Divino Espírito Santo no Maranhão: uma proposta de glossário. 2008, 179 f. Dissertação (Mestrado em Linguística) - Programa de Pós-graduação em Linguística, Universidade Federal do Ceará, Fortaleza, 2008.

ROCHA, Rafael Stoppa. A negação dupla no português paulistano. 2013. 87f. Dissertação (Mestrado em Semiótica e Linguística Geral) - Programa de Pósgraduação em Semiótica e Linguística Geral - Faculdade de Filosofia, Letras e Ciências Humanas, Universidade de São Paulo, São Paulo, 2013.

ROCHA, Rosa. C. F. da. A alternância indicativo/subjuntivo nas orações subordinadas substantivas em português. 1997. 123f. Dissertação (Mestrado em Linguística) - Departamento de Linguística, Línguas Clássicas e Vernáculas, Universidade de Brasília, Brasília, 1997.

SANKOFF, D.; TAGLIAMONTE, S.; SMITH, E. Goldvarb X: A variable rule application for Macintosh and Windows. Department of Linguistics, University of Toronto, 2005.

SANTOS, Georgiana Márcia Oliveira. A terminologia do reggae ludovicense: uma abordagem socioterminológica. 2009, 237 f. Dissertação (Mestrado em Linguística) - Programa de Pós-graduação em Linguística, Universidade Federal do Ceará, Fortaleza, 2009.

SANTOS, Regina M. A. dos. O uso variável do modo subjuntivo em estruturas complexas. 2005. 170f. Dissertação (Mestrado em Estudos Linguísticos) Instituto de Biociências, Letras e Ciências Exatas, Universidade Estadual Paulista, São Jose do Rio Preto, 2005.

SANTOS, Wendel Silva dos. Atlas Linguístico do Maranhão: o pretérito imperfeito e o futuro do pretérito do indicativo no português falado no Maranhão - a variação de usos para a expressão de hipótese. São Luís, 2011. 99f. Monografia (Licenciatura em Letras) - Curso de Graduação em Letras, Universidade Federal do Maranhão, São Luís, 2011.

SERRA, Astolfo. Guia Histórico e Sentimental de São luís do Maranhão. Rio de Janeiro: Editora Civilização Brasileira S.A, 1965.

TRAVAGLIA, Luis C. Gramática e Interação: uma proposta para o ensino de gramática no $1^{\circ}$ e $2^{\circ}$ graus. São Paulo: Cortez, 1996.

VIEIRA FILHO, Domingos. A linguagem popular do Maranhão. 2. ed. São Luís, 1958.

VIEIRA, Marília Silva. Aí, dai e então como articuladores de orações em Campo Grande (MS) e São Paulo (SP). Projeto de Doutorado (CAPES) apresentado ao Programa de Pós-Graduação em Semiótica e Linguística Geral do DL-FFLCHUSP, 2013. Ms. 
VOTRE, Sebastião. J. Relevância da variável escolaridade. In: MOLLICA, Maria C.; BRAGA, Maria Luiza. (Orgs.). Introdução à sociolinguística variacionista: o tratamento da variação. São Paulo: Contexto, 2003. pp. 51-58.

WEINREICH, Uriel, LABOV, William \& HERZOG, Marvin I. Empirical foundations for a theory of language change. In: Lehmann, W.P. \& Malkiel, Y. (Eds.), Directions for Historical Linguistics: A Symposium, 1968.

WHERRITT, Irene. M. The subjunctive in Brazilian Portuguese. 1977. 191f. Tese (Doutorado em Filosofia) - Department of Modern and Classical Languages, University of New Mexico, Albuquerque, 1977. 
- ANEXOS - 


\section{Anexo A: Roteiro das entrevistas paulistanas}

\section{SP2010: construção de uma amostra da fala paulistana" \\ (Processo Fapesp n² 2011/09278-6)}

\section{Roteiro da entrevista}

I. Primeira parte

BAIRRO (aprox. $10 \mathrm{~min}$.)

Objetivos: descobrir o "grau de enraizamento" do informante no bairro onde vive/outros bairros; descobrir padrões de sociabilidade nos diferentes bairros; descobrir o "grau de mobilidade" da pessoa.

1. Há quanto tempo você mora na (Mooca, Pinheiros, Bexiga...)?

2. Você gosta de morar aqui?

3. Por que você escolheu morar neste bairro? (manter em mente que o informante pode não ter "escolhido" morar ali: pode ter sido porque a família já morava lá etc.)

a. (Se o informante mora há bastante tempo) Como era o bairro antes/quando você se mudou pra cá? Mudou muito?

b. (Se o informante não mora lá há muito tempo, ou se nem sempre viveu ali) Em que outros lugares você já morou? Como era lá comparado com esse bairro aqui? Onde você preferia morar?

4. Você conhece seus vizinhos?

5. O que esse bairro tem de diferente de outros bairros na cidade?

6. Aqui costuma haver festas do bairro? Existe algum lugar no bairro em que as pessoas se reúnem?

7. As pessoas se ajudam por aqui?

a. Se você precisa de ajuda, a quem você recorre? Se você ficar doente, a quem você pode pedir para tomar conta de sua família?

8. Com quais pessoas você tem mais contato?

9. Já aconteceu alguma coisa aqui que te fez pensar em se mudar?

10. Hoje, tem algum outro bairro em que você gostaria de morar?

INFANCIA (aprox. 5 min.) 
Objetivos: relaxar o informante (em geral, as pessoas gostam de falar de sua infância); obter informações sobre mudanças no bairro/cidade de São Paulo; grau de mobilidade do informante; obter informações sobre escolaridade

11. E como foi a sua infância (no bairro X)? Você pode contar um pouco de como foi, o que você fazia...?

a. brincava na rua/dentro de casa? Do que vocês brincavam?

b. Como eram os seus pais? Eram rígidos...? Você tinha horário para estar em casa?

c. Vocês tinham alguma tradição de familia?

12. Você foi pra escola no mesmo bairro? Como era a escola? Você sempre estudou na mesma escola? Você gostava de ir pra escola? Tem algum professor que te marcou? Até que série você estudou? Você acha que a escola fornece aquilo que uma pessoa precisa para encontrar um emprego?

13. Enquanto ainda era criança/adolescente, você ia pra outros lugares dentro da cidade de São Paulo? (pra onde, pra fazer o quê...)

14. Que roupas você usava? Que tipo de corte de cabelo as pessoas usavam?

FAMILIA (aprox. 5 min.)

Objetivos: obter informações sobre rede social do informante, grau de enraizamento no bairro/cidade

15. Você tem irmãos? (é possível que esta informação já tenha aparecido na parte sobre infância; neste caso, falar algo como: "Você disse que tem uma irmã... Você tem outros irmãos?") Quantos anos eles têm?

16. Onde seus pais nasceram? (Se não são paulistanos, perguntar também sobre avós, bisavós... até encontrar a primeira geração da família que veio pra cá). Quantos anos eles (pais) têm? Quando seus (pais/avós/bisavós) vieram pra São Paulo? Você sabe por que eles vieram?

17. E o resto da família, tios, primos, também vivem aqui em São Paulo? (Se sim, em que bairros? Moram próximo? Se não, onde? Têm contato sempre?)

18. Você é casado? Você tem filhos? Quantos anos eles têm?

19. Quais são as pessoas que vivem na mesma casa que você?

20. Como é a vida em família hoje em São Paulo?

a. É muito diferente de quando você era criança? (Para os mais velhos)

b. É muito diferente do que seus pais contam para você? (Para os mais jovens)

c. Muitas pessoas falam que as crianças hoje são mal-educadas. O que você acha disso? Você acha que as crianças hoje têm menos respeito pelos adultos? 
21. No passado, esperava-se que as mulheres ficassem em casa para tomar conta das crianças. E hoje, como é isso? Mudou?

a. Em sua casa, os homens ajudam nos afazeres domésticos? O que você acha de um homem ficar em casa e cuidar dos filhos?

22. O que você acha da lei sobre casamento gay, que foi recentemente aprovada?

TRABALHO/OCUPAÇÃO (aprox. 5 min.)

Objetivos: obter informações sobre rede social do informante; características socioeconômicas

23. Você trabalha aqui por perto? (se não souber onde a pessoa trabalha)

24. Como você faz para chegar até o seu trabalho? Quais meios de transporte você utiliza?

25. O que você faz? Faz tempo que você trabalha nesse serviço?

26. Você gosta do seu serviço? (Se não, o que a pessoa preferiria fazer?)

27. Você se sente reconhecido no seu trabalho?

28. Você quer alcançar outro cargo? O que você almeja no seu trabalho?

29. Qual é a profissão dos seus sonhos?

30. Se você ganhasse na mega-sena, o que você faria?

31. As pessoas devem continuar trabalhando, mesmo se elas têm muito dinheiro?

LAZER (aprox. 5 min.)

Objetivos: obter informações sobre rede social do informante; mobilidade na cidade; características socioeconômicas

32. E nas horas de lazer, o que você e sua família gostam de fazer? (Se saem, vão pra que lugares?) Você acha que a cidade de São Paulo tem boas opções de lazer? Quais?

33. A maioria dos seus amigos mora aqui nesse bairro mesmo? (Se não, onde?)

34. Você tem algum atividade de recreação em grupo, algum clube...?

35. Quais são seus amigos mais antigos? Você mantém contato com os amigos de colégio?

36. Você costuma viajar? Pra que lugares já viajou? Que lugares gostaria de conhecer?

II. Segunda parte

A CIDADE DE SÃO PAULO (aprox. 20 min.)

37. Uma pesquisa recente mostrou que 57\% das pessoas em São Paulo deixariam a cidade caso pudessem. O que você acha disso? (se o informante perguntar, a pesquisa é do Ibope e foi publicada em janeiro/201039)

\footnotetext{
39 Disponivel em:

$<$ http://www.nossasaopaulo.org.br/portal/arquivos/Pesquisa_IRBEM_Ibope_2010_

completa.pdf $>$. Último acesso em dezembro de 2014.
} 
38. Você gosta de morar em São Paulo? (Se não, em que lugar preferiria morar?) Por quê? 39. O que você acha que caracteriza a cidade (tanto as coisas boas quanto ruins)? 40. O que você acha que caracteriza o paulistano (tanto as coisas boas quanto ruins)? 41. Olhando pra mim, você diria que eu sou paulistano(a)? Por quê?

42. O que você mais gosta em São Paulo?

43. O que você não gosta em São Paulo? (a depender do tópico mencionado pelo informante - violência, trânsito, poluição etc. - procurar explorar mais o assunto. P.ex.: você já foi assaltado? O que aconteceu? (para obter narrativa pessoal) O que o governo deve fazer pra solucionar esse problema? (para obter uma fala mais distanciada)) (explorar o subtópico por aproximadamente $10 \mathrm{~min}$.)

44. Pras pessoas que não vivem em São Paulo, como você acha que elas imaginam que seja a cidade? Qual é a imagem que as pessoas de fora de São Paulo têm da cidade?

45. Você falou que já foi pra $(X, Y, Z)$. Quando você foi pra esses lugares, as pessoas percebiam que você era paulistano? (Se sim) como elas percebiam?

46. Quando você conhece alguém, você percebe se a pessoa não é daqui de São Paulo?

a. (Se sim) como você percebe? (Se o informante mencionar o modo de falar, seguir nessa linha e tentar conseguir informações mais precisas. É normal as pessoas não saberem definir o porquê, mas devemos tentar tirar mais informações).

b. (Se não) Quando você ouve uma pessoa falando, por exemplo, você percebe que ela é de fora pelo sotaque?

PRODUÇÃO/PERCEPÇÃO/AVALIAÇÃO LINGUÍSTICA (aprox. 10 min.)

47. Já que a gente está falando de sotaque... qual o sotaque do Brasil que você mais gosta? E tem algum que te irrita? Como é que (o gaúcho/o carioca/o mineiro/o caipira etc. - a depender dos sotaques mencionados) fala(m)?

48. Aqui em São Paulo tem muito (i)migrante, né? De onde vêm a maioria das pessoas? Tem algum bairro específico em que eles (italianos, coreanos, nordestinos etc.) se concentram? Hoje em dia, existem bairros étnicos em São Paulo?

49. E como é que as pessoas falam na cidade de São Paulo? (evitar usar a palavra "sotaque")

50. Dentro da cidade de São Paulo, você consegue identificar se a pessoa é de alguma região ou bairro específico da cidade? (Se sim) Você poderia dar alguns exemplos?

(Imprimir a lista de palavras, a notícia e o trecho, todos abaixo, para mostrar ao informante)

LISTA de PALAVRAS: 
Apresentar ao informante a lista de palavras e dizer: "Agora eu queria te pedir pra ler algumas coisas. Eu tenho aqui uma lista de palavras, e eu queria que você lesse cada uma delas. Você pode dar uma olhada primeiro, antes de começar a ler." Esperar que o informante leia a lista de palavras. Depois perguntar:

51. A gente estava falando de sotaques agora há pouco... Como você acha que uma pessoa do interior falaria algumas dessas palavras? Tem diferenças?

52. E como um carioca falaria algumas dessas palavras?

53. Tem mais algum sotaque no Brasil que você conhece?

\section{LEITURA DE NOTÍCIA:}

Dizer ao informante: "Agora eu queria que você lesse esse texto. Você pode ler em voz baixa antes de falar em voz alta." Esperar que o informante leia a notícia.

\section{LEITURA DE TRECHO:}

Dizer ao informante: "Por último, queria que você lesse esse trechinho." Esperar que o informante leia o trecho.

54. (Sobre /e/ nasal) O que você acha desse modo de falar: "Você tá entendendo o que eu tô dizendo?" (com "en" ditongado e exagerado). Se a pessoa manifestar uma atitude negativa, perguntar: Como você acha que deveria ser? O que tem de errado aî?

55. Quem você acha que fala assim? (se falar "paulistanos", perguntar: "você acha que todos os paulistanos falam assim ou é uma coisa de uma região mais específica na cidade?")

56 . Você fala desse modo?

57. (Sobre concordância nominal) E o que você acha de "Me vê dois pastel e um chopps?" (Repetir as perguntas 52-53)

58. (Sobre /r/ retroflexo) E o que você acha de "A porta tá aberta." (com retroflexo exagerado). (Repetir as perguntas 52-53).

59. E tem algum modo de falar que você acha assim bem paulistano? 
Palavras

\begin{tabular}{|c|c|}
\hline alma & gula \\
\hline amargo & Hércules \\
\hline animação & hilário \\
\hline argola & irmã \\
\hline atitude & justiça \\
\hline barqueiro & lento \\
\hline biscoito & mortadela Marba \\
\hline cacique & mosca \\
\hline carteiro & necessidade \\
\hline cerca & noite \\
\hline chácara & orca \\
\hline circo & Ordem e progresso \\
\hline cisne & orgânico \\
\hline curto & órgão \\
\hline defender & ostracismo \\
\hline discoteca & penteado \\
\hline elefante & pertencimento \\
\hline enchente & perto \\
\hline entender & porto \\
\hline entretenimento & presente \\
\hline erguer & rapidez \\
\hline fazenda & riqueza \\
\hline felicidade & sabor de menta \\
\hline firme & soberba \\
\hline fornalha & trabalho \\
\hline furgão & turco \\
\hline fusquinha & urgente \\
\hline geleira & utilidade \\
\hline gérmen de trigo & vulto \\
\hline gordo & zebra \\
\hline
\end{tabular}


Notícia

$08 / 02 / 2010$

Moradores cobram solução para área alagada em SP e aguardam encontro com prefeito Moradores da região do Jardim Pantanal protestaram nesta segunda-feira em frente à Prefeitura de São Paulo contra a inundação em bairros da zona leste, que completa dois meses hoje. Uma comissão de manifestantes foi recebida pela Secretaria de Relações Institucionais e apresentou reivindicações, mas o prefeito Gilberto Kassab (DEM) não participou do encontro.

Representantes dos manifestantes esperam que o governador José Serra (PSDB) também participe da reunião de sexta. De acordo com os integrantes da comissão, não havia integrantes do governo estadual no encontro realizado hoje na prefeitura.

Além de cobrar a limpeza imediata das águas nos bairros, os moradores cobram uma solução para a falta de moradia. A maioria dos desalojados continua em escolas municipais e, com o início do ano letivo, temem não ter para onde ir. 
Trecho

Tá chovendo muito! Choveu tanto, tanto na semana passada que ficou uma piscina na minha casa. Ó, pra você ver: Molharam todos os armários, a cama, os colchões, tudo... Foi um sacrificio... O que a gente fez? Nós tivemos que erguer os móveis pra limpar tudo: a geladeira, o forno... minha irmã até veio me ajudar, sabe? E meus filhos compraram umas cadeiras novas, mas é aquela coisa, assim... quando chover de novo, vai molhar tudo outra vez. Você fica sem ter o que fazer. E tem um rio lá perto que sempre alaga... quer dizer, é água dentro e fora de casa! Daí, o que acontece? Fica aquele trânsito, os carros todos parados, a gente demora um tempão pra chegar em casa... Não aguento mais enchente nessa cidade... Agora que eu vou fazer? Os políticos falam, falam, mas eles tinham que fazer alguma coisa urgente. Você tá entendendo o que eu tô dizendo? 


\section{Anexo B: Roteiro das entrevistas ludovicenses}

\section{Roteiro da entrevista}

I. Primeira parte

BAIRRO (aprox. $10 \mathrm{~min}$.)

Objetivos: descobrir o "grau de enraizamento" do informante no bairro onde vive/outros bairros; descobrir padrões de sociabilidade nos diferentes bairros; descobrir o "grau de mobilidade" da pessoa.

1. Há quanto tempo você mora na (Calhau, Cohatrac, Cohab...)?

2. Você gosta de morar aqui?

3. Por que você escolheu morar neste bairro? (manter em mente que o informante pode não ter "escolhido" morar ali: pode ter sido porque a família já morava lá etc.)

a. (Se o informante mora há bastante tempo) Como era o bairro antes/quando você se mudou pra cá? Mudou muito?

b. (Se o informante não mora lá há muito tempo, ou se nem sempre viveu ali) Em que outros lugares você já morou? Como era lá comparado com esse bairro aqui? Onde você preferia morar?

4. Você conhece seus vizinhos?

5. O que esse bairro tem de diferente de outros bairros na cidade?

6. Aqui costuma haver festas do bairro? Existe algum lugar no bairro em que as pessoas se reúnem?

7. As pessoas se ajudam por aqui?

a. Se você precisa de ajuda, a quem você recorre? Se você ficar doente, a quem você pode pedir para tomar conta de sua família?

8. Com quais pessoas você tem mais contato?

9. Já aconteceu alguma coisa aqui que te fez pensar em se mudar?

10. Hoje, tem algum outro bairro em que você gostaria de morar?

INFANCIA (aprox. 5 min.)

Objetivos: relaxar o informante (em geral, as pessoas gostam de falar de sua infância); obter informações sobre mudanças no bairro/cidade de São Luís; grau de mobilidade do informante; obter informações sobre escolaridade

11. E como foi a sua infância (no bairro X)? Você pode contar um pouco de como foi, o que você fazia...?

a. brincava na rua/dentro de casa? Do que vocês brincavam? 
b. Como eram os seus pais? Eram rígidos...? Você tinha horário para estar em casa?

c. Vocês tinham alguma tradição de família?

12. Você foi pra escola no mesmo bairro? Como era a escola? Você sempre estudou na mesma escola? Você gostava de ir pra escola? Tem algum professor que te marcou? Até que série você estudou? Você acha que a escola fornece aquilo que uma pessoa precisa para encontrar um emprego?

13. Enquanto ainda era criança/adolescente, você ia pra outros lugares dentro da cidade de São Luís? (pra onde, pra fazer o quê...)

14. Que roupas você usava? Que tipo de corte de cabelo as pessoas usavam?

FAMILIA (aprox. 5 min.)

Objetivos: obter informações sobre rede social do informante, grau de enraizamento no bairro/cidade

15. Você tem irmãos? (é possível que esta informação já tenha aparecido na parte sobre infância; neste caso, falar algo como: "Você disse que tem uma irmã... Você tem outros irmãos?") Quantos anos eles têm?

16. Onde seus pais nasceram? (Se não são ludovicenses, perguntar também sobre avós, bisavós... até encontrar a primeira geração da família que veio pra cá). Quantos anos eles (pais) têm? Quando seus (pais/avós/bisavós) vieram pra São Luís? Você sabe por que eles vieram?

17. E o resto da família, tios, primos, também vivem aqui em São Paulo? (Se sim, em que bairros? Moram próximo? Se não, onde? Têm contato sempre?)

18. Você é casado? Você tem filhos? Quantos anos eles têm?

19. Quais são as pessoas que vivem na mesma casa que você?

20. Como é a vida em família hoje em São Luís?

a. É muito diferente de quando você era criança? (Para os mais velhos)

b. É muito diferente do que seus pais contam para você? (Para os mais jovens)

c. Muitas pessoas falam que as crianças hoje são mal-educadas. O que você acha disso? Você acha que as crianças hoje têm menos respeito pelos adultos?

21. No passado, esperava-se que as mulheres ficassem em casa para tomar conta das crianças. E hoje, como é isso? Mudou?

a. Em sua casa, os homens ajudam nos afazeres domésticos? O que você acha de um homem ficar em casa e cuidar dos filhos?

22. O que você acha da lei sobre casamento gay, que foi recentemente aprovada?

TRABALHO/OCUPAÇÃO (aprox. 5 min.) 
Objetivos: obter informações sobre rede social do informante; características socioeconômicas

23. Você trabalha aqui por perto? (se não souber onde a pessoa trabalha)

24. Como você faz para chegar até o seu trabalho? Quais meios de transporte você utiliza?

25. O que você faz? Faz tempo que você trabalha nesse serviço?

26. Você gosta do seu serviço? (Se não, o que a pessoa preferiria fazer?)

27. Você se sente reconhecido no seu trabalho?

28. Você quer alcançar outro cargo? O que você almeja no seu trabalho?

29. Qual é a profissão dos seus sonhos?

30. Se você ganhasse na mega-sena, o que você faria?

31. As pessoas devem continuar trabalhando, mesmo se elas têm muito dinheiro?

LAZER (aprox. 5 min.)

Objetivos: obter informações sobre rede social do informante; mobilidade na cidade; características socioeconômicas

32. E nas horas de lazer, o que você e sua família gostam de fazer? (Se saem, vão pra que lugares?) Você acha que São Luís tem boas opções de lazer? Quais?

33. A maioria dos seus amigos mora aqui nesse bairro mesmo? (Se não, onde?)

34. Você tem algum atividade de recreação em grupo, algum clube...?

35. Quais são seus amigos mais antigos? Você mantém contato com os amigos de colégio? 36. Você costuma viajar? Pra que lugares já viajou? Que lugares gostaria de conhecer?

\section{Segunda parte}

A CIDADE DE SÃO Luís (aprox. 20 min.)

37. De acordo com dados do IBGE, São Luís possui o $12^{\circ}$ maior parque industrial entre as 27 capitais do brasil e é considerada, pela FGV (Fundação Getúlio Vargas como uma das melhores cidades, no país, para se trabalhar. ${ }^{40}$ )

38. Você gosta de morar em São Luís? (Se não, em que lugar preferiria morar?) Por quê?

39. O que você acha que caracteriza a cidade (tanto as coisas boas quanto ruins)?

40. O que você acha que caracteriza o ludovicense (tanto as coisas boas quanto ruins)?

41. Olhando pra mim, você diria que eu sou ludovicense? Por quê?

42. O que você mais gosta em São Luís?

43. O que você não gosta em São Luís? (a depender do tópico mencionado pelo informante - violência, trânsito, poluição etc. - procurar explorar mais o assunto. P.ex.: você já foi

\footnotetext{
40 Informações extraídas do site da prefeitura de São luís, Disponiveis em: <http://www.saoluis.ma.gov.br/frmPagina.aspx?idpagina_web=2>. Ültimo acesso em dezembro de 2013.
} 
assaltado? O que aconteceu? (para obter narrativa pessoal) O que o governo deve fazer pra solucionar esse problema? (para obter uma fala mais distanciada)) (explorar o subtópico por aproximadamente $10 \mathrm{~min}$.

44. Pras pessoas que não vivem em São Luís, como você acha que elas imaginam que seja a cidade? Qual é a imagem que as pessoas de fora de São Luís têm da cidade?

45. Você falou que já foi pra (X, Y, Z). Quando você foi pra esses lugares, as pessoas percebiam que você era ludovicense? (Se sim) como elas percebiam?

46. Quando você conhece alguém, você percebe se a pessoa não é daqui de São Luís?

a. (Se sim) como você percebe? (Se o informante mencionar o modo de falar, seguir nessa linha e tentar conseguir informações mais precisas. É normal as pessoas não saberem definir o porquê, mas devemos tentar tirar mais informações).

b. (Se não) Quando você ouve uma pessoa falando, por exemplo, você percebe que ela é de fora pelo sotaque?

PRODUÇÃO/PERCEPÇÃO/AVALIAÇÃO LINGUÍSTICA (aprox. 10 min.)

47. Já que a gente está falando de sotaque... qual o sotaque do Brasil que você mais gosta? E tem algum que te irrita? Como é que (o paulistano/o carioca/o paraense/o caipira etc. - a depender dos sotaques mencionados) fala(m)?

48. Aqui em São Luís a gente vê a presença de imigrantes? (A depender da resposta dada pelo informante, perguntar se sabe de onde vem essas pessoas). Tem algum bairro específico em que eles se concentram? Hoje em dia, existem bairros étnicos em São Luís?

49. E como é que as pessoas falam na cidade de São Luís? (evitar usar a palavra "sotaque")

50. Dentro da cidade de São Luís, a gente consegue identificar se a pessoa é de alguma região ou bairro específico da cidade? (Se sim) Você poderia dar alguns exemplos?

(Imprimir a lista de palavras, a notícia e o trecho, todos abaixo, para mostrar ao informante)

LISTA de PALAVRAS:

Apresentar ao informante a lista de palavras e dizer: "Agora eu queria te pedir pra ler algumas coisas. Eu tenho aqui uma lista de palavras, e eu queria que você lesse cada uma delas. Você pode dar uma olhada primeiro, antes de começar a ler." Esperar que o informante leia a lista de palavras. Depois perguntar: 
51. A gente estava falando de sotaques agora há pouco... Como você acha que uma pessoa do interior falaria algumas dessas palavras? Tem diferenças?

52. E como um paulista/paulistano falaria algumas dessas palavras?

53. Tem mais algum sotaque no Brasil que você conhece?

\section{LEITURA DE NOTÍCIA:}

Dizer ao informante: "Agora eu queria que você lesse esse texto. Você pode ler em voz baixa antes de falar em voz alta.” Esperar que o informante leia a notícia.

\section{LEITURA DE TRECHO:}

Dizer ao informante: "Por último, queria que você lesse esse trechinho." Esperar que o informante leia o trecho.

54. (Sobre /e/ nasal) O que você acha desse modo de falar: "Você tá entendendo o que eu tô dizendo?" (com "en" ditongado e exagerado). Se a pessoa manifestar uma atitude negativa, perguntar: Como você acha que deveria ser? O que tem de errado aî?

55. Quem você acha que fala assim? (se falar "paulistanos", perguntar: "você acha que todos os paulistanos falam assim ou é uma coisa de uma região mais específica na cidade?")

56. Você fala desse modo?

57. (Sobre concordância nominal) E o que você acha de "Me vê dois pastel e um chopps?” (Repetir as perguntas 52-53)

58. (Sobre /r/ retroflexo e tepe) E o que você acha de "A porta tá aberta." (com retroflexo e tepe exagerados). (Repetir as perguntas 52-53).

59. E tem algum modo de falar que você acha assim bem ludovicense? 
Palavras

alma

Hércules

amargo

hilário

animação

irmã

argola

justiça

atitude

lento

barqueiro

mortadela Marba

biscoito

mosca

cacique

necessidade

carteiro

noite

cerca

orca

chácara

Ordem e progresso

circo

orgânico

cisne

órgão

curto

ostracismo

defender

penteado

discoteca

pertencimento

elefante

perto

enchente

porto

entender

presente

entretenimento

rapidez

erguer

riqueza

fazenda

sabor de menta

felicidade

soberba

firme

trabalho

fornalha

turco

furgão

urgente

fusquinha

utilidade

geleira

vulto

gérmen de trigo

zebra

gordo

gula 
Notícia

A Companhia de Saneamento Ambiental do Maranhão (Caema) confirmou para as $9 \mathrm{~h}$ desta quinta-feira (21), o início da manutenção elétrica preventiva do Sistema Italuís, interrompendo temporariamente o fornecimento de água para ao menos 150 bairros da capital maranhense.

De acordo com a assessoria da Caema, a manutenção deve durar até às 13h, atingindo aproximadamente $60 \%$ dos bairros da capital maranhense. O tempo para normalização do abastecimento de água é de até $72 \mathrm{~h}$, e a companhia também informou que a segunda etapa dessa manutenção acontecerá em 5 de julho, em horário ainda a ser definido.

Apesar de confirmar a manutenção, a assessoria da Caema informou que não foi realizado um levantamento para estimar quantas pessoas serão afetadas com a medida. 
Trecho

Tá chovendo muito! Choveu tanto, tanto na semana passada que ficou uma piscina na minha casa. Ó, pra você ver: Molharam todos os armários, a cama, os colchões, tudo... Foi um sacrificio... O que a gente fez? Nós tivemos que erguer os móveis pra limpar tudo: a geladeira, o forno... minha irmã até veio me ajudar, sabe? E meus filhos compraram umas cadeiras novas, mas é aquela coisa, assim... quando chover de novo, vai molhar tudo outra vez. Você fica sem ter o que fazer. E tem um rio lá perto que sempre alaga... quer dizer, é água dentro e fora de casa! Daí, o que acontece? Fica aquele trânsito, os carros todos parados, a gente demora um tempão pra chegar em casa... Não aguento mais enchente nessa cidade... Agora que eu vou fazer? Os políticos falam, falam, mas eles tinham que fazer alguma coisa urgente. Você tá entendendo o que eu tô dizendo? 
- APÊNDICES - 
Apêndice A

Número total de verbos codificados para o grupo de fatores Verbo da Oração Principal (conjunto de dados de orações substantivas)

\begin{tabular}{cccccc}
\hline Verbo & $\begin{array}{c}\mathbf{N} \\
\text { Indicativo }\end{array}$ & $\boldsymbol{\%}$ & $\begin{array}{c}\text { N / \% } \\
\text { Subjuntivo }\end{array}$ & $\mathbf{\%}$ & Total \\
\hline Achar & 55 & 69,6 & 24 & 30,4 & 79 \\
Pensar & 14 & 70 & 6 & 30 & 20 \\
Imaginar & 16 & 76,2 & 5 & 23,8 & 21 \\
Supor & 2 & 33,3 & 4 & 66,7 & 6 \\
Crer & 9 & 64,3 & 5 & 35,7 & 14 \\
Acreditar & 34 & 55,7 & 27 & 44,3 & 61 \\
Duvidar & 2 & 100 & 0 & - & 2 \\
Perceber & 3 & 100 & 0 & - & 3 \\
Deduzir & 0 & - & 1 & 100 & 1 \\
Entender & 1 & 100 & 0 & - & 1 \\
Querer & 3 & 6,7 & 42 & 93,3 & 45 \\
Pedir & & & & & 7 \\
Exigir & 0 & - & 3 & 100 & 3 \\
Esperar & 0 & - & 6 & 100 & 6 \\
Cobrar & 0 & - & 1 & 100 & 1 \\
Proibir & & & & & 1 \\
Preferir & 1 & 20 & 4 & 80 & 5 \\
Gostar & 4 & 25 & 12 & 75 & 16 \\
Fingir & 1 & 100 & 0 & - & 1 \\
Precisar & 1 & 25 & 3 & 75 & 4 \\
Ir & 0 & - & 2 & 100 & 2 \\
Provocar & 0 & - & 1 & 100 & 1 \\
Permitir & 0 & - & 3 & 100 & 3 \\
Estabelecer & 5 & 100 & 0 & - & 5 \\
Falar & 0 & - & 1 & 100 & 1 \\
Concordar & 1 & 33,3 & 2 & 66,7 & 3 \\
Importar-se & 0 & - & 1 & 100 & 1 \\
Dizer & 4 & 36,4 & 7 & 63,6 & 11 \\
Comentar & 1 & 100 & 0 & - & 1 \\
Conseguir & 1 & 20 & 4 & 80 & 5 \\
Admitir & 0 & - & 3 & 100 & 3 \\
Incentivar & 0 & - & 1 & 100 & 1 \\
Prejudicar & 0 & - & 2 & 100 & 2 \\
Fazer & 2 & 40 & 3 & 60 & 5 \\
Evitar & 0 & - & 1 & 100 & 1 \\
Deixar & 0 & - & 4 & 100 & 4 \\
Suportar & 0 & - & 1 & 100 & 1 \\
Bastar & 0 & - & 2 & 100 & 2 \\
Facilitar & 0 & - & 1 & 100 & 1 \\
Detestar & 0 & - & 1 & 100 & 1 \\
Ser & 0 & - & 15 & 100 & 15 \\
\hline
\end{tabular}




\section{Apêndice B:}

Número total de subordinadores codificados para o grupo de fatores Tipo de Subordinador (conjunto de dados de orações adverbiais)

\begin{tabular}{cccccc}
\hline Subordinador & $\begin{array}{c}\mathbf{N} \\
\text { Indicativo }\end{array}$ & $\%$ & $\begin{array}{c}\text { N/\% } \\
\text { Subjuntivo }\end{array}$ & $\%$ & Total \\
\hline se & 180 & 26,3 & 504 & 684 & 684 \\
embora & 7 & 38,9 & 11 & 61,1 & 18 \\
talvez & 27 & 29,7 & 64 & 70,3 & 91 \\
tomara que & 1 & 100 & 0 & - & 1 \\
quando & 12 & 75 & 4 & 25 & 16 \\
enquanto & 0 & - & 3 & 100 & 3 \\
qualquer & 0 & - & 1 & 100 & 1 \\
provavelmente & 1 & 50 & 1 & 50 & 2 \\
mesmo que & 5 & 33,3 & 10 & 66,7 & 15 \\
antes que & 1 & 50 & 1 & 50 & 2 \\
apesar que / apesar de que & 5 & 83,3 & 1 & 16,7 & 6 \\
nem que & 0 & - & 6 & 100 & 6 \\
não que/ não é que / & 22 & 39,3 & 34 & 60,7 & 56 \\
não é porque / não porque & 3 & 15 & 17 & 85 & 20 \\
a não ser que & 0 & - & 14 & 100 & 14 \\
por mais que & 1 & 20 & 4 & 80 & 5 \\
contanto que & 3 & 100 & 0 & - & 3 \\
vai que & 1 & 14,3 & 6 & 85,7 & 7 \\
desde que & 0 & - & 5 & 100 & 5 \\
pelo que & 6 & 85,7 & 1 & 14,3 & 7 \\
para que & 0 & - & 1 & 100 & 1 \\
tão logo & 0 & - & 1 & 100 & 1 \\
ainda que & 2 & 100 & 0 & - & 2 \\
de modo que & 0 & - & 3 & 100 & 3 \\
sem que & 0 & - & 2 & 100 & 2 \\
a menos que & 1 & 50 & 1 & 50 & 2 \\
com que & 0 & - & 3 & 100 & 3 \\
até que & 0 & - & 1 & 100 & 1 \\
à medida que & & & & & \\
\hline
\end{tabular}

